\title{
Rare earth element behavior during groundwater - seawater mixing along the Kona Coast of Hawaii
}

\author{
Karen H. Johannesson ${ }^{a}$, C. Dianne Palmore ${ }^{a}$, Joseph Fackrell ${ }^{b}$, Nancy G. Prouty ${ }^{c}$, Peter \\ W. Swarzenski ${ }^{\mathrm{c}, \mathrm{d}}$, Darren A. Chevis ${ }^{\mathrm{a}}$, Katherine Telfeyan ${ }^{\mathrm{a}, \mathrm{e}}$, Christopher D. White ${ }^{\mathrm{a}}$, and \\ David J. Burdige
}

${ }^{\mathrm{a}}$ Department of Earth and Environmental Sciences, Tulane University, New Orleans, LA 70118

${ }^{b}$ Department of Geology and Geophysics, University of Hawaii at Manoa, Honolulu, HI 96822

${ }^{c}$ United States Geological Survey, Pacific Coastal and Marine Science Center, Santa Cruz, CA 95060

${ }^{\mathrm{d}}$ International Atomic Energy Agency, 98000 Monaco

${ }^{\mathrm{e}}$ Earth and Environmental Sciences Division, Los Alamos National Laboratory, Los Alamos, NM 87545

${ }^{\mathrm{f}}$ Department of Ocean, Earth, and Atmospheric Sciences, Old Dominion University, Norfolk, VA 23529

*Corresponding author (kjohanne@tulane.edu) 


\section{Abstract}

Groundwater and seawater samples were collected from nearshore wells and offshore along the Kona Coast of the Big Island of Hawaii to investigate rare earth element (REE) behavior in local subterranean estuaries. Previous investigations showed that submarine groundwater discharge (SGD) is the predominant flux of terrestrial waters to the coastal ocean along the arid Kona Coast of Hawaii. Groundwater and seawater samples were filtered through $0.45 \mu \mathrm{m}$ and $0.02 \mu \mathrm{m}$ pore-size filters to evaluate the importance of colloidal and soluble (i.e., truly dissolved ionic species and/or low molecular weight [LMW] colloids) fractions of the REEs in the local subterranean estuaries. Mixing experiments using groundwater collected immediately down gradient from a wastewater treatment facility (WWTF) proximal to the Kaloko-Hanokohau National Historic Park, and more "pristine" groundwater from a well constructed in a lava tube at Kiholo Bay, were mixed with local seawater to study the effect of solution composition (i.e., $\mathrm{pH}$, salinity) on the concentrations and fractionation behavior of the REEs as groundwater mixes with seawater in Kona Coast subterranean estuaries. The mixed waters were also filtered through 0.45 or $0.02 \mu \mathrm{m}$ filters to ascertain the behavior of colloidal and soluble fractions of the REEs across the salinity gradient in each mixing experiment. Concentrations of the REEs were statistically identical (two-tailed Student $t$ test, $95 \%$ confidence) between the sequentially filtered sample aliquots, indicating that the REEs occur as dissolved ionic species and/or LMW colloids in Kona Coast groundwaters. The mixing experiments revealed that the REEs are released to solution from suspended particles or colloids when Kona Coast groundwater waters mix with local seawater. The order of release that accompanies increasing $\mathrm{pH}$ and salinity follows 
light REE (LREE) > middle REE (MREE) > heavy REE (HREE). Release of REEs in the mixing experiments is driven by decreases in the free metal ion activity in solution and the concomitant increase in the amount of each REE that occurs in solution as dicarbonato complexes [i.e., $\operatorname{Ln}\left(\mathrm{CO}_{3}\right)_{2}^{-}$] as $\mathrm{pH}$ increases across the salinity gradient. Input-normalized REE patterns of Kona Coast groundwater and coastal seawater are nearly identical and relatively flat compared to North Pacific seawater, indicating that SGD is the chief source of these trace elements to the ocean along the Kona Coast. Additionally, REE concentrations of the coastal seawater are between 10 and 50 times higher than previously reported open-ocean seawater values from the North Pacific, further demonstrating the importance of SGD fluxes of REEs to these coastal waters. Taken together, these observations indicate that large-scale removal of REEs, which characterizes the behavior of REEs in the low salinity reaches of many surface estuaries, is not a feature of the subterranean estuary along the Kona Coast. A large positive gadolinium (Gd) anomaly characterizes groundwater from the vicinity of the WWTF. The positive Gd anomaly can be traced to the coastal ocean, providing further evidence of the impact of SGD on the coastal waters. Estimates of the SGD fluxes of the REEs to the coastal ocean along the Kona Coast (i.e., $1.3-2.6 \mathrm{mmol} \mathrm{Nd} \mathrm{day}^{-1}$ ) are similar to recent estimates of SGD fluxes of REEs along Florida's east coast and to Rhode Island Sound, all of which points to the importance of SGD as significant flux of REEs to the coastal ocean. 


\section{Introduction}

Submarine groundwater discharge (SGD) is increasingly recognized as an important flux of water, nutrients, and metals to the coastal ocean (Moore, 2010). Although the volume of fresh SGD to the ocean is commonly small compared to river discharge, geochemical reactions in subterranean estuaries (e.g., Moore, 1999) can generate substantial fluxes of nutrients, carbon, and metals to the coastal ocean (Moore, 1997; Cai et al., 2003; Charette and Buesseler, 2004; Slomp and van Cappellen, 2004; Charette et al., 2005; Kim et al., 2005; Windom et al., 2006; Roy et al., 2010, 2011; Johannesson et al., 2011; Chevis et al., 2015a, b). Submarine groundwater discharge includes all flow of water from the seafloor into the overlying marine water column within continental margin regions, regardless of chemical composition and physical driving force (Church, 1996; Burnett et al., 2003; Moore, 2010). Thus, SGD includes "fresh submarine groundwater discharge" that originates from meteoric recharge of terrestrial aquifers, as well as "recirculated saline submarine groundwater discharge", which includes water that cycles through coastal aquifers caused by wave set-up, tidal pumping, geothermal or density gradients, and/or bioirrigation (Taniguchi et al., 2002). These components of SGD are commonly referred to as "terrestrial SGD" and "marine SGD”, respectively, and their sum represents the total SGD (Martin et al., 2007; Roy et al., 2010).

The rare earth elements (REEs, also known as lanthanides) have been utilized to study the petrogenesis of magmatic rocks and for tracing the circulation and mixing of oceanic water masses (Jakeš and Gill, 1970; Hanson, 1980; Piepgras and Wasserburg, 1987; McKenzie and O'Nions, 1991). The effectiveness of the REEs as tracers of 
geochemical reactions and processes chiefly reflects their uniform trivalent charge $\left(\mathrm{Ce}^{4+}\right.$ and $\mathrm{Eu}^{2+}$ can also occur), and the gradual decrease in their ionic radii with increasing atomic number (i.e., the lanthanide contraction) that accompanies the progressive filling of the $4 f$-electron shell across the REE series. Consequently, the REEs exhibit strong fractionation as a group due to size and charge, as well as important "within-group" fractionation that result from the lanthanide contraction (see Johannesson et al. 2005, 2014; and references therein). These distinctive features of the REEs can accordingly provide insight into complex and subtle geochemical processes that other, single element tracers cannot readily discriminate (Quinn et al. 2004; Johannesson et al. 2005, 2014).

Investigations of the REEs in surface water estuaries reveal substantial removal of dissolved REEs (i.e., filtrates that passed through $0.45 \mu \mathrm{m}$ or $0.22 \mu \mathrm{m}$ pore size filters; Sholkovitz, 1992) where river waters first mix with seawater (Martin et al., 1976; Goldstein and Jacobsen, 1988a; Elderfield et al., 1990; Sholkovitz, 1993, 1995; Sholkovitz and Szymczak, 2000). Removal of REEs in the low salinity reaches of estuaries reflects salt-induced coagulation and flocculation of Fe-rich, organic colloids, which scavenge and fractionate the REEs such that the order of removal is light REE (LREE) > middle REE (MREE) > heavy REEs (HREE; Sholkovitz, 1995). At higher salinities the REEs are released back to solution owing to diagenetic reactions within estuarine sediments and/or displacement from surface sites on suspended particles by more abundant competing cations (Sholkovitz, 1995; Sholkovitz and Szymczak, 2000). Here, the order of release also follows LREE > MREE > HREE. Consequently, the characteristic HREE enriched, shale-normalized REE fractionation pattern that characterizes seawater (which originates in part during chemical weathering of 
continental rocks) is further modified by the competitive effects of aqueous and surface complexation reactions acting on REEs during their transport to the ocean in rivers and estuaries (i.e., Nesbitt, 1979; Hoyle et al., 1984; Goldstein and Jacobsen, 1988b; Elderfield et al., 1990; Sholkovitz, 1995; Byrne and Liu, 1998).

Despite numerous investigations of surface water estuaries, much less is known about the processes that control REE concentrations and fractionation in subterranean estuaries, as well as the importance of SGD fluxes of REEs are for the ocean on a global basis (Duncan and Shaw, 2003; Johannesson and Burdige, 2007; Johannesson et al., 2011; Kim and Kim, 2011; Chevis et al., 2015a, b). Interest in SGD fluxes of REEs to the ocean also stems in part from the possibility that SGD could be an important component of the "missing Nd flux" that would balance the global Nd budget and address the "Nd paradox" (Goldstein and Hemming, 2003; Johannesson and Burdige, 2007). The "Nd paradox" refers to the apparent decoupling of dissolved Nd concentrations, whereby $\mathrm{Nd}$ concentrations exhibit nutrient-like profiles in the ocean (indicating vertical cycling and, hence, long residence times, $\sim 10^{4}$ years), and $\mathrm{Nd}$ isotope ratios that exhibit inter- and intra-oceanic variations that preclude vertical cycling and support $\mathrm{Nd}$ residence times that are similar to or less than the oceanic mixing time $(\sim 500-1500$ years; Bertram and Elderfield, 1993; Jeandel et al., 1995, 1998; Tachikawa et al., 1997, 1999a, b, 2003; Lacan and Jeandel, 2001; Goldstein and Hemming, 2003; Siddall et al., 2008; Arzouze et al., 2009). Current estimates of riverine and atmospheric fluxes appear to be roughly an order of magnitude too low to balance the global ocean Nd budget and preserve the interand intra-oceanic $\mathrm{Nd}$ isotope ratios. The source of the missing $\mathrm{Nd}$ flux is thought to reflect "boundary exchange", which is a broadly defined process that involves exchange 
of Nd between the continental shelf and the ocean (Lacan and Jeandel, 2005; Jeandel et al., 2013), and likely includes SGD (Johannesson and Burdige, 2007; Chevis et al., 2015a, b). Indeed, recent studies demonstrate that SGD associated with small volcanic islands, including the Hawaiian Islands, have a measureable impact on the REE concentrations and $\mathrm{Nd}$ isotope signatures of coastal waters as well as surface waters in the open ocean (Kim and Kim, 2011, 2014; Fröllje et al., 2016).

In this contribution we expand on our investigations of REE cycling in subterranean aquifers by presenting REE concentration data for groundwaters and seawater from the arid, Kona Coast of Hawaii where previous investigations have demonstrated the existence of large, nutrient-rich plumes of groundwater, and extensive diffuse seeps of SGD to the coastal ocean (e.g., Johnson et al., 2008; Street et al., 2008; Knee et al., 2010). We employ a modification of the product approach for mixing experiments pioneered by Sholkovitz (1976) to study processes that control REE concentrations and fractionation across the salinity gradient of Kona Coast subterranean estuaries.

\section{Setting}

The study site is located on the arid western coast of the island of Hawaii (Fig. 1), where the overwhelming majority of meteoric water that falls in the region is discharged to the adjacent coastal ocean via SGD (Oki et al., 1999; Duarte et al., 2006; Johnson et al., 2008; Tillman et al., 2014a; Prouty et al., 2016). Precipitation within the immediate study region (e.g., Kaloko - Honokohau National Historic Park) ranges from 500 - 760 $\mathrm{mm} \mathrm{a}^{-1}$, whereas annual pan evaporation exceeds $1700 \mathrm{~mm}$ (Ekern and Chang, 1985; Oki 
et al., 1999). Consequently, little recharge, if any, of the local aquifers occurs within the study site. Instead, groundwater recharge is thought to occur further inland to the east at elevations 300-600 $\mathrm{m}$ above sea level, where the precipitation exceeds $1500 \mathrm{~mm} \mathrm{a}^{-1}$ (Oki et al., 1999; see also Fig. EA1 in the electronic annex). Groundwater from the study region is unconfined and generally brackish with salinity increasing with depth (Oki et al., 1999). Fresh (i.e., potable) groundwater exists further inland as thin lenses on top of the brackish layer as well as inland at higher elevations where groundwaters are impounded at higher head levels by low permeability structures thought to consist of buried, igneous dike complexes (Zucca et al., 1982; Oki et al., 1999; Tillman et al., 2014a, b).

The local geology is characterized by extensive basaltic lava flows that are highly permeable to groundwater flow caused to widespread brecciation of lava flow tops (e.g., 'A' $\bar{a}$ lava), cooling fractures, clinker zones, and the presence of lava tubes (Oki et al., 1999; Lau and Mink, 2006). The basaltic rocks exposed at the surface of the study site are alkalic (i.e., chiefly alkali olivine basalt) and were erupted from Hualalai Volcano during the Holocene and late Pleistocene (e.g., Clague and Dalrymple, 1987; Moore et al., 1987; Moore and Clague, 1987; Hanano et al., 2010). Minor amounts of hawaiites are associated with these surficial alkali olivine basalts flows, whereas trachyte erupted from the Puu Waawaa cone (Clague et al., 1980; Moore et al., 1987; Clague and Bohrson, 1991; Hanano et al., 2010; Fig. 1). Although not exposed at the surface, the bulk of Hulalai Volcano is thought to be composed of tholeiites erupted during the main shield volcano building stage that is hypothesized to account for the formation of the Hawaiian 
Islands (Clague and Dalrymple, 1987; Moore and Clague, 1987, 1992; Moore et al., 1987).

Previous studies demonstrated that a substantial amount of groundwater discharges to the coastal ocean along the Kona Coast (Adams and Lepley, 1968; Bienfeng, 1980; Oki et al., 1999; Duarte et al., 2006; Peterson et al., 2007; Johnson et al., 2008; Knee et al., 2010). We focus here on SGD in the vicinity of the Honokohau small boat harbor (hereafter, Honokohau Harbor), a portion of the Kaloko-Hanokohau (i.e., KAHO) National Historic Park located immediately to the north, as well as at Kiholo Bay, roughly $23 \mathrm{~km}$ north of Honokohau Harbor (Fig. 1). Honokohau Harbor was constructed by excavating a $>5 \mathrm{~m}$ deep channel and basin within the local bedrock during the 1970s (Bienfang, 1980). In the process, the excavation intercepted a lava tube that supplies the bulk of the terrestrial SGD to the harbor and adjacent coastal ocean (Johnson et al., 2008).

Recent mass balance models using ${ }^{222} \mathrm{Rn}$ inventories, salinity, and water fluxes suggest that total SGD from Honokohau Harbor to the coastal ocean is on the order of $12,000 \mathrm{~m}^{3} \mathrm{day}^{-1}$, of which approximately $72 \%$ (i.e., $8600 \mathrm{~m}^{3}$ day $^{-1}$ ) is terrestrial sourced SGD, and the remaining $3400 \mathrm{~m}^{3} \mathrm{day}^{-1}$ (28\%) represents re-circulated marine SGD (Johnson et al., 2008; Peterson et al., 2009). Based on an approximate width of $65 \mathrm{~m}$ for the harbor mouth, these values imply along shore SGD fluxes of $182 \mathrm{~m}^{3}$ day ${ }^{-1}$ per meter of shoreline (128 L m $\mathrm{Lm}^{-1}$ ) for total SGD, and $132 \mathrm{~m}^{3} \mathrm{day}^{-1}$ per meter of shoreline (92 $\mathrm{L} \mathrm{m}^{-1} \mathrm{~min}^{-1}$ ) for terrestrial SGD. Other studies have reported higher SGD fluxes, with estimates for fresh and brackish SGD between 274 and $1872 \mathrm{~m}^{3}$ day $^{-1}$ per meter of shoreline (190 and $1300 \mathrm{~L} \mathrm{~m}^{-1} \mathrm{~min}^{-1}$; Knee et al., 2010; Gallagher, 1980). 


\section{Methods}

\subsection{Sample collection}

All sampling and laboratory plasticware (HDPE, Teflon ${ }^{\circledR}$ ), including filters, were cleaned prior to use by following standard trace element cleaning procedures (e.g., Johannesson et al., 2004; Fitzsimmons and Boyle, 2012, 2014). Groundwater samples were collected from wells in the vicinity of Honokohau Harbor, the Kaloko-Honokohau National Historic Park (i.e., KAHO wells), and from the Hind "well" located near Kiholo Bay (Fig. 1). The Hind "well" is essentially a fracture in the surface basalt flow that exposes an underlying, partially saturated lava tube. The Honokohau Harbor well is located down hydrologic gradient from the Kealakehe waterwater treatment facility (WWTF), which is thought to cause the high influx of nutrients to the harbor (Oki et al., 1999; Johnson et al., 2008; Prouty et al., 2016). Indeed, between 4900 and $6400 \mathrm{~m}^{3}$ of effluent from the WWTF is discharged per day into an excavated pit located roughly 1 km up gradient from Honokohau Harbor (Parsons et al., 2008). Consequently, groundwater from the Honokohau Harbor well was chosen for study because it has been impacted by anthropogenic-sourced nutrients. In contrast, the Hind "well" was sampled because it is located far from direct anthropogenic sources within a region of the Kona coast that is not highly developed. The KAHO wells sample groundwater from north of Honokohau Harbor, where Johnson et al. (2008) identified large, point source fluxes of SGD to the coastal ocean. Finally, we collected seawater from directly offshore, $\sim 0.62$ $\mathrm{km}$ from the mouth of Honokohau Harbor for REE analysis and for the mixing experiments described below (Fig. 1). 
Groundwater was collected from each well using a Fultz pump (Fultz Pumps, Inc., Lewiston, PA) connected to the surface with LDPE tubing. To be sure that water samples collected from the wells were representative of groundwaters within the aquifers/subterranean estuaries and not the well bore, water temperature, specific conductance, and $\mathrm{pH}$ were continuously monitored during well purging, and water sample collection did not begin until all three parameters had stabilized, which was typically equivalent to three well volumes (Prouty et al., 2016). Groundwater and seawater samples were collected into large volume (i.e., $10 \mathrm{~L}$ and $40 \mathrm{~L}$, respectively), pre-cleaned HDPE carboys, and subsequently transported back to the field laboratory for processing, mixing experiments, and preservation prior to analysis.

At the laboratory, aliquots of groundwaters from each well, as well as the coastal seawater sample, were sequentially filtered first through $0.45 \mu \mathrm{m}$ high-capacity (Gelman Sciences, polyether sulfone membrane, Pall Corporation, Port Washington, NY) filter capsules and then through $0.02 \mu \mathrm{m}$ pore-size filters (Whatman, Anotop alumina) syringe filters (e.g., Shiller, 2003; Fitzsimmons and Boyle, 2012, 2014), and collected into precleaned HDPE sample bottles. These samples were then acidified to $\mathrm{pH}<2$ with ultrapure nitric acid (Optima Grade, Thermo Fisher), double bagged in pre-cleaned, Ziplock ${ }^{\circledR}$-style, polyethylene bags, and stored cold at $\sim 4^{\circ} \mathrm{C}$ in plastic chests until analysis for the REEs. The sequential filtering approach was chosen to separate the dissolved pool of the REEs (i.e., $0.45 \mu \mathrm{m}$ passing filtrate) into a colloidal fraction (passed through $0.45 \mu \mathrm{m}$ filter but not through $0.02 \mu \mathrm{m}$ filter $)$ from the soluble fraction $(0.02 \mu \mathrm{m}$ passing filtrate; Prouty et al., 2016). The soluble fraction therefore consists of ionic species and low molecular weight (LMW) colloids (Fitzsimmons and Boyle, 2014). 


\subsection{Subterranean estuary mixing experiments}

Groundwater-seawater mixing experiments were conducted on unfiltered and unacidified water samples on the same day the water samples were collected. Using the seawater sample (i.e., $40 \mathrm{~L}$ ) collected offshore near the mouth of Honokohau Harbor, two distinct groundwater-seawater mixing experiments were performed, one using groundwater from the Honokohau Harbor well, and the other using groundwater from the more "pristine" Hind well (i.e., Lava tube mixing experiment). Although the coastal seawater sample is appropriate for the Honokohau Harbor mixing experiment, it may not be representative of coastal seawater from Kiholo Bay, and hence, for the Lava tube mixing experiment. For each mixing experiment aliquots of groundwater from the Honokohau Harbor well or the Hind well were mixed in various proportions with the seawater sample to achieve a series of samples with salinities ranging from $\leq 2$ to $\sim 36.7$;

we refer to this mixing path as endpoint mixing (e.g., Hoyle et al., 1984; Garnier and Guieu, 2003; Schneider et al., 2016). We recognize that serial dilution is an alternative model that could also simulate mixing processes in subterranean estuaries. Both approaches can only approximate the actual mixing path in these settings.

After equilibrating the mixtures for 2 hours (Prouty et al., 2016), aliquots of the mixed water samples were sequentially filtered through $0.45 \mu \mathrm{m}$ and then $0.02 \mu \mathrm{m}$ poresize filters as described above, and subsequently acidified to $\mathrm{pH}<2$ with ultrapure nitric acid (Optima Grade, Thermo Fisher). The total time between sample collection and acidification was on the order of 3 hours for the $0.45 \mu \mathrm{m}$ filtered aliquots, and 4 hours for the $0.02 \mu \mathrm{m}$ filtered aliquots. The mixing and sample processing times were chosen to 
minimize REE adsorption onto the bottle walls (Fitzsimmons and Boyle, 2012, 2014). The acidified aliquots were then double bagged in pre-cleaned, Zip-lock ${ }^{\circledR}$-style, polyethylene bags, and stored cold at $\sim 4^{\circ} \mathrm{C}$ in plastic chests until analysis for REEs.

\subsection{Chemical analysis}

Major cation and anion concentrations in the groundwaters, the coastal seawater sample, and each mixed water sample from both mixing experiments were determined using high-resolution (magnetic sector) inductively coupled plasma mass spectrometry (HR-ICP-MS Themo Fisher Element 2; Tulane University) and ion chromatography (U.S. Geological Survey, Menlo Park, CA), respectively. Nutrients were analyzed at the Woods Hole Oceanographic Institution by flow injection analysis as described in Prouty et al. (2016). Dissolved organic carbon (DOC) concentrations were quantified by high temperature combustion using a Shimadzu TOC-500 total carbon analyzer as described previously (Burdige and Gardner, 1998). Dissolved Fe and Mn concentrations were measured by HR-ICP-MS following methods described by Roy et al. (2010) and Mohajerin et al. (2016).

Groundwater, seawater, and composite waters from the mixing experiments were analyzed for the REEs using similar methods to those described previously (Johannesson et al., 2005, 2011; Willis and Johannesson, 2011; Chevis et al., 2015a, b). Briefly, $30 \mathrm{~mL}$ aliquots of the filtered (both 0.45 and $0.02 \mu \mathrm{m}$ pore-size filters) and acidified samples, $0.45 \mu \mathrm{m}$ filtered and acidified laboratory and field blanks, and the National Research Council Canada (Ottawa, Ontario, Canada) Standard Reference Material (SRM) for estuarine waters (SLEW-3) were first loaded onto Poly-Prep columns (Bio-Rad 
Laboratories) packed with AG 50W-X8 (100 - 200 mesh, hydrogen form, Bio-Rad Laboratories) cation-exchange resin at approximately $1 \mathrm{~mL}^{\text {minute }}{ }^{-1}$ to separate REEs from the major salts (e.g., Elderfield and Greaves, 1983; Greaves et al., 1989; Klinkhammer et al., 1994; Johannesson et al., 2005, 2011). Iron and Ba were then quantitatively eluted from each column using $1.75 \mathrm{M}$ ultra-pure $\mathrm{HCl}$ (Optima Grade, Thermo Fisher) and $2 \mathrm{M}$ ultra-pure $\mathrm{HNO}_{3}$ (Optima Grade, Thermo Fisher), respectively (Greaves et al., 1989). The REEs were subsequently eluted from the columns using $8 \mathrm{M}$ ultra-pure $\mathrm{HNO}_{3}$ (Optima Grade, Thermo Fisher) and collected in Teflon ${ }^{\circledR}$ beakers. The eluent was then taken to dryness on a hot plate, and the residue redissolved in $10 \mathrm{~mL}$ of a $1 \% \mathrm{v} / \mathrm{v}$ ultra-pure $\mathrm{HNO}_{3}$ solution. All sample processing was conducted in an ISO 5 rated clean room or ISO 5 rated laminar flow bench (i.e., class 100).

Each $10 \mathrm{~mL}$ sample was then spiked with ${ }^{115} \mathrm{In}$ as an internal standard and analyzed for the REEs by HR-ICP-MS (Thermo Fisher Element 2) at Tulane University. We examined ${ }^{139} \mathrm{La},{ }^{140} \mathrm{Ce},{ }^{141} \mathrm{Pr},{ }^{143} \mathrm{Nd},{ }^{145} \mathrm{Nd},{ }^{146} \mathrm{Nd},{ }^{147} \mathrm{Sm},{ }^{149} \mathrm{Sm},{ }^{151} \mathrm{Eu},{ }^{153} \mathrm{Eu},{ }^{155} \mathrm{Gd}$, ${ }^{157} \mathrm{Gd},{ }^{158} \mathrm{Gd},{ }^{159} \mathrm{~Tb},{ }^{161} \mathrm{Dy},{ }^{163} \mathrm{Dy},{ }^{165} \mathrm{Ho},{ }^{166} \mathrm{Er},{ }^{167} \mathrm{Er},{ }^{169} \mathrm{Tm},{ }^{172} \mathrm{Yb},{ }^{173} \mathrm{Yb}$, and ${ }^{175} \mathrm{Lu}$ (lowand medium-resolution mode) because most of these isotopes are free of isobaric interferences (Shannon and Wood, 2005; Johannesson et al., 2005; 2011). Furthermore, monitoring more than one isotope of a given element provides an additional check for potential interferences. Europium isotopes $\left({ }^{151} \mathrm{Eu}\right.$ and $\left.{ }^{153} \mathrm{Eu}\right)$ as well as the heavy REEs (HREE) were also monitored in high-resolution mode, which allowed us to resolve interferences on ${ }^{151} \mathrm{Eu}$ and ${ }^{153} \mathrm{Eu}$ from $\mathrm{BaO}^{+}$species formed in the plasma stream, and LREEO $^{+}$and $\mathrm{MREEO}^{+}$species on the HREEs. The HR-ICP-MS was calibrated and the concentrations of REEs in the samples verified using a series of REE calibration 
standards of known concentrations $\left(1 \mathrm{ng} \mathrm{kg}^{-1}, 2 \mathrm{ng} \mathrm{kg}^{-1}, 5 \mathrm{ng} \mathrm{kg}^{-1}, 10 \mathrm{ng} \mathrm{kg}^{-1}, 100 \mathrm{ng} \mathrm{kg}^{-}\right.$ 1, $500 \mathrm{ng} \mathrm{kg}^{-1}$, and $1000 \mathrm{ng} \mathrm{kg}^{-1}$ ). The calibration standards were prepared from NIST traceable High Purity Standards (Charleston, SC). In addition, check standards for the REEs were prepared using Perkin Elmer multi-element solutions. The detection limit for then REEs ranged between 0.5 and 6 pmol kg${ }^{-1}$, whereas the field blank exhibited REE concentrations between $1.4 \mathrm{pmol} \mathrm{kg}^{-1}$ for $\mathrm{Lu}$ and $35 \mathrm{pmol} \mathrm{kg}^{-1}$ for Ce (Table EA1). Analytical precision of the REE analyses was always better than $4 \%$ relative standard deviation (RSD), and generally better than $2 \% \mathrm{RSD}$, whereas accuracy of the analyses for SLEW-3 were typically within $\pm 5 \%$ of the values reported by Lawrence and Kamber (2006).

\subsection{Geochemical modeling}

Solution complexation modeling of the REEs in Kona groundwaters, coastal seawater, and the water samples from the mixing experiments was achieved using the SpecE8 and React programs of the Geochemist's Workbench ${ }^{\circledR}$ (release 9.0; Bethke, 2008; Bethke and Yeakel, 2013). The Lawrence Livermore National Laboratory database (Delaney and Lundeen, 1989) provided with the software (i.e., thermo.dat) was modified by addition of the 14 naturally occurring REEs and their corresponding inorganic, aqueous complexes with carbonate, phosphate, hydroxyl, sulfate, chloride, and fluoride ions. Specifically, infinite dilution stability constants for the $\mathrm{LnHCO}_{3}{ }^{2+}, \mathrm{LnCO}_{3}{ }^{+}$, and $\operatorname{Ln}\left(\mathrm{CO}_{3}\right)_{2}{ }^{-}$complexes, where $\mathrm{Ln}$ is any of the 14 naturally occurring REEs (i.e., lanthanides), that were added to the database are from Luo and Byrne (2004), those for $\mathrm{LnPO}_{4}{ }^{0}$ and $\mathrm{Ln}\left(\mathrm{PO}_{4}\right)_{2}{ }^{3-}$ are from Byrne et al. (1991) and Lee and Byrne (1992), those for 
$\mathrm{LnOH}^{+}$are from Klungness and Byrne (2000), those for $\mathrm{LnSO}_{4}{ }^{+}$are from Schijf and Byrne (2004), those for $\mathrm{LnCl}^{2+}$ are from Luo and Byrne (2001), and those describing the formation of $\mathrm{LnF}^{2+}$ complexes are from Luo and Byrne (2000). In addition, because a number of studies have demonstrated that REE phosphate co-precipitate phases limit the solubility of REEs in natural waters (Jonasson et al., 1985; Byrne and Kim, 1993; Johannesson et al., 1995), we included the solubility product constants for $\mathrm{LnPO}_{4(\mathrm{~s})}$ phases estimated by Liu and Byrne (1997) in the thermo. dat database to account for solubility limitations on the REEs in the geochemical modeling.

The partitioning of the REEs between suspended particles or colloids and the dissolved phase in natural waters can be characterized as a competition between sorption reactions and the formation of aqueous complexes (Byrne and Kim, 1990; Erel and Morgan, 1991; Erel and Stolper, 1993; Quinn et al., 2004). Because we did not measure or characterize the REE content or surface chemistry of suspended particles or colloids from Kona Coast groundwaters, a quantitative evaluation of sorption reactions involving the REEs is currently not possible. Nevertheless, a partitioning model that allows for the evaluation of the relative solution and surface complexation behavior of the REEs in the Kona Coast groundwaters can be formulated using methods described previously (e.g., see Balistrieri et al., 1981; Clegg and Sarmiento, 1989; Byrne and Kim, 1990; Dzombak and Morel, 1990; Erel and Morgan, 1991). The partitioning model, which is described in detail in the electronic annex, computes the distribution of each REE between the aqueous solution and surface sites on suspended particles or colloids as a function of the composition of the aqueous solution. Furthermore, by normalizing the computed distribution coefficients to the same REE, the necessity of knowing the concentration of 
the adsorption sites on the suspended particles or colloids is eliminated (Byrne and Kim, 1990; Erel and Morgan, 1991; Erel and Stolper, 1993). Following Byrne and Kim (1990), we chose to normalize the distribution coefficients to $\mathrm{Gd}$, which is located in the middle of the REE series, such that the relative distribution coefficient for each REE is represented by

$$
D_{\mathrm{Ln}} / D_{\mathrm{Gd}}=\left([\mathrm{Ln}]_{\mathrm{T}, \text { ads }} /[\mathrm{Ln}]_{\mathrm{T}, \text { soln }}\right) /\left([\mathrm{Gd}]_{\mathrm{T}, \text { ads }} /[\mathrm{Gd}]_{\mathrm{T}, \text { soln }}\right)
$$

where $[\mathrm{Ln}]_{\mathrm{T} \text {,ads }}$ and $[\mathrm{Gd}]_{\mathrm{T} \text {,ads }}$ are the total concentrations of any given $\mathrm{REE}$ and $\mathrm{Gd}$ adsorbed on particles and/or colloids, respectively, and $[\mathrm{Ln}]_{\mathrm{T} \text {,soln }}$ and $[\mathrm{Gd}]_{\mathrm{T} \text {,soln }}$ are the corresponding total concentrations in solution. It is critical to point out, however, that distribution coefficients computed in this fashion are independent of the measured REE concentrations, and instead are only a function of the ionic strength corrected equilibrium constants that describe the formation of the various REE solution complexes with different ligands, and the corresponding free ligand concentrations in solution (see equations EA1 - EA8). Therefore, the anomalously high Gd concentrations that characterize groundwaters from the Honokohau Harbor well and the associated mixing experiment (see below) do not affect the calculation of the distribution coefficients.

To determine the solution complexation term (equations EA1-EA4), the formation of bicarbonate, carbonato, dicarbonato, hydroxide, chloride, sulfate, phosphate, and diphosphato complexes of the REEs were considered (see HH_Speciation.xlsx and LT_Speciation.xlsx in electronic annex). Free ligand concentrations were computed for each sample from both mixing experiments using the SPECE8 program of the Geochemist's Workbench $^{\circledR}$ (release 9.0; Bethke, 2008; Bethke and Yeakel, 2013). 
Infinite dilution stability constants were then corrected to the appropriate ionic strength (Tables A1, A2) using the approach of Millero and Schreiber (1982) as discussed in Schijf and Byrne (2004) where, for example,

$$
\log \underset{\mathrm{CO}_{3}}{\operatorname{Ln}} \beta_{1}=\log \underset{\mathrm{CO}_{3}}{\operatorname{Ln}} \beta_{1}^{0}+\log \left(\frac{\gamma_{\mathrm{Ln}^{3}+\gamma_{\mathrm{CO}_{3}^{2-}}}}{\gamma_{\mathrm{LnCO}_{3}^{+}}}\right)
$$

in which ${ }_{\mathrm{CO}_{3}}^{\mathrm{Ln}} \beta_{1}^{0}$ is the stability constant describing the formation of the carbonato complex at $I=0 \mathrm{~mol} \mathrm{~kg}^{-1}$, and $\gamma_{i}$ are the activity coefficients for each species at the given ionic strength of the water sample.

\section{Results}

\subsection{Geochemistry of Kona groundwaters}

The major solute compositions of the Kona groundwaters are presented in Table 2 along with nutrient concentrations and other ancillary geochemical parameters. The groundwater are chiefly $\mathrm{Na}-\mathrm{HCO}_{3}$ type waters, although groundwater from the KAHO 2 well is a Na-Cl water with major ion ratios similar to coastal seawater (Fig. 2). The Kona groundwaters are brackish as demonstrated by their measured salinities and electrical conductivities, as well as their computed ionic strengths (Table 2). Groundwater $\mathrm{pH}$ ranges between 6.76 and 7.7 and Eh (computed based on the high dissolved oxygen concentrations) ranges from 0.763 to 0.817 volts. Groundwater from the Honokohau Harbor well exhibits elevated nutrient (i.e., $\mathrm{NO}_{3}+\mathrm{NO}_{2}, \mathrm{PO}_{4}$; Prouty et al., 2016) and DOC concentrations compared to the other well waters sampled, again reflecting its proximity to the Kealakehe WWTF (Table 2, Fig. 1). The Kona groundwaters also have relatively high dissolved silica concentrations (311 to $432 \mu \mathrm{mol} \mathrm{kg}{ }^{-1}$; Table 2), which likely reflect chemical weathering of basaltic glass within the aquifer rocks (e.g., Visher 
and Mink, 1964; Lau and Mink, 2006). High dissolved silica concentrations have been reported for other groundwaters from basalt aquifers (e.g., Stefánsson and Gíslason, 2001).

Dissolved Fe, Mn, and DOC concentrations (i.e., passed through $0.45 \mu \mathrm{m}$ filters) of groundwaters from Kona Coast subterranean estuaries are substantially lower than observed in our previous studies of subterranean estuaries beneath the Indian River Lagoon in Florida and the Pettaquamscutt River estuary in Rhode Island (Roy et al., 2010; Johannesson et al., 2011; Chevis et al., 2015a, b). Iron, Mn, and DOC concentrations in the Kona Coast groundwaters range between 11 and $63 \mathrm{nmol} \mathrm{kg}^{-1}, 0.6$ and $12 \mathrm{nmol} \mathrm{kg}^{-1}$, and 36 and $236 \mu \mathrm{mol} \mathrm{kg}{ }^{-1}$, respectively (Table 2). By comparison, Fe, $\mathrm{Mn}$, and DOC concentrations in groundwaters from the Indian River Lagoon subterranean estuary range from 0.009 to $286 \mu \mathrm{mol} \mathrm{kg}^{-1}, 0.06$ to $2.9 \mu \mathrm{mol} \mathrm{kg}^{-1}$, and $\sim 80$

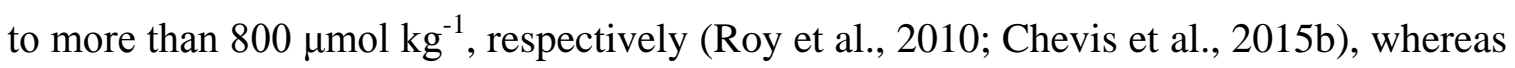
Fe and DOC range between 1 and $6.5 \mathrm{mmol} \mathrm{kg}^{-1}$, and 380 and $7300 \mu \mathrm{mol} \mathrm{kg}{ }^{-1}$, respectively, in groundwaters from the Pettaquamscutt River estuary (Chevis et al., 2015a). Furthermore, the concentrations of Fe, Mn, and DOC in the subterranean estuary beneath the Kona Coast are also generally lower than the concentrations of these species in the majority of surface estuaries where the REEs have also been investigated (Table 3). The exception is groundwater from the Honokohau Harbor well, which exhibits DOC concentrations similar to some surface estuaries. 


\subsection{REE concentrations and input-normalized fractionation patterns}

Rare earth element concentrations for coastal seawater and coastal groundwaters from the Kona Coast are presented in Table 4. Rare earth element concentrations of these coastal groundwaters are, on average, lower than in groundwaters from the Indian River Lagoon subterranean estuary in Florida (Johannesson et al., 2011; Chevis et al., 2015b). Specifically, Nd concentrations of Kona Coast groundwaters (i.e., filtered through 0.45 $\mu \mathrm{m}$ pore-size filters) range from $158 \mathrm{pmol} \mathrm{kg}-1$ to $192 \mathrm{pmol} \mathrm{kg}^{-1}$, and have a mean $( \pm \mathrm{SD})$ $\mathrm{Nd}$ concentration of $178 \pm 12.9 \mathrm{pmol} \mathrm{kg}^{-1}$ (Table 4), whereas $\mathrm{Nd}$ concentrations measured in SGD from the Indian River Lagoon in Florida that were collected identically (i.e., $0.45 \mu \mathrm{m}$ pore-size filters) range from $110 \mathrm{pmol} \mathrm{kg}^{-1}$ to $2409 \mathrm{pmol} \mathrm{kg}^{-1}$, and exhibit a mean $( \pm \mathrm{SD}) \mathrm{Nd}$ concentration of $448 \pm 365 \mathrm{pmol} \mathrm{kg}^{-1}(\mathrm{n}=55$; Johannesson et al., 2011; Chevis et al., 2015b). If the sample with the highest $\mathrm{Nd}$ concentration from the Indian River Lagoon subterranean estuary (i.e., $\left.2409 \mathrm{pmol} \mathrm{kg}^{-1}\right)$ is not included, the mean $( \pm \mathrm{SD})$ $\mathrm{Nd}$ concentration of the remaining samples is $412 \pm 252 \mathrm{pmol} \mathrm{kg}^{-1}$, which is still more than 2-fold higher, on average, than the mean $\mathrm{Nd}$ concentration of Kona Coast groundwaters. In contrast, groundwaters discharging to the Pettaquamscutt River estuary in Rhode Island generally exhibit lower REE concentrations than Kona Coast groundwaters. For example, Nd concentrations range from $0.43 \mathrm{pmol} \mathrm{kg}^{-1}$ to $198 \mathrm{pmol}$ $\mathrm{kg}^{-1}$ and exhibit a mean $( \pm \mathrm{SD})$ of $35.2 \pm 79.8 \mathrm{pmol} \mathrm{kg}^{-1}$ in Pettaquamscutt groundwaters $(n=6$; Chevis et al., 2015a). Recent investigations of coastal groundwaters from Jeju Island in Korea (i.e., Kim and Kim, 2011, 2014) reported substantially higher REE concentrations for identically filtered ( $0.45 \mu \mathrm{m}$ pore size filters) samples compared to groundwaters from the Kona Coast, the Indian River Lagoon, and the Pettaquamscutt 
River estuary. Specifically, the mean $( \pm \mathrm{SD}) \mathrm{Nd}$ concentration for coastal groundwaters from Jeju Island is $2672 \pm 1357 \mathrm{pmol} \mathrm{kg}^{-1}(\mathrm{n}=16$; Kim and Kim, 2011). Although Jeju Island is also largely composed of basaltic rocks in addition to more evolved volcanic rocks such as trachyandesites and trachytes (Tatsumi et al., 2004), the Nd concentrations of the coastal groundwaters are 15-fold higher, on average, than the $\mathrm{Nd}$ concentrations of Kona Coast groundwater.

An outstanding feature of the Kona Coast groundwater data is that the REE concentrations of water filtered through $0.02 \mu \mathrm{m}$ pore-size filters are statistically indistinguishable (Student's $t$-test; $\mathrm{p}>0.05$ ) from those filtered through $0.45 \mu \mathrm{m}$ poresize filters (Table 4, Fig. 3). The REE concentrations of the groundwaters are also similar to those of the coastal seawater sample (Table 2; Fig. 4). Specifically, the $\mathrm{Nd}$ concentration of the coastal seawater sample (filtered through $0.45 \mu \mathrm{m}$ pore-size filters) is $169 \mathrm{pmol} \mathrm{kg}^{-1}$ compared to $158-192 \mathrm{pmol} \mathrm{kg}^{-1}$ for the groundwaters (Table 4). Moreover, the REE concentrations of the Kona Coast seawater samples are substantially higher than open-ocean seawater from the North Pacific (Fig. 4). For example, Alibo and Nozaki (1999) report $\mathrm{Nd}$ concentrations that range between 6.64 and $24.5 \mathrm{pmol} \mathrm{kg}^{-1}$ (mean $\pm \mathrm{SD}$ $=15.6 \pm 6.5 \mathrm{pmol} \mathrm{kg}^{-1}$ ) for seawater from the Northwest Pacific Ocean, and Piepgras and Jacobsen (1992) present Nd data for the North Pacific that range between 5 and 63 pmol $\mathrm{kg}^{-1}$ (mean $\pm \mathrm{SD}=29 \pm 14.3 \mathrm{pmol} \mathrm{kg}^{-1}$ ). It is important to note that the REE data presented by Alibo and Nozaki (1999) were filtered through $0.04 \mu \mathrm{m}$ pore-size filters, whereas those from Piepgras and Jacobsen (1992) are for unfiltered water samples. Consequently, the data from Alibo and Nozaki (1999) would include colloids larger than those sampled by the $0.02 \mu \mathrm{m}$ pore-size filters used here for Kona seawater, whereas the 
REE concentrations for North Pacific seawater presented by Piepgras and Jacobsen (1992) represent the maximum concentrations of the REEs in the analyzed seawater samples (i.e., dissolved, colloidal, and particulate). For either case, REE concentrations for Kona Coast seawater exceed those for North Pacific seawater by at least a factor of 7 , and as much as a factor of 29 for the LREEs. Thus, the enrichment of REEs in Kona Coast seawater compared to North Pacific seawater can not be explained by particulate or colloidal association of REEs in Kona Coast seawaters because the $0.02 \mu \mathrm{m}$ filtered coastal seawater is enriched in REEs over the $0.04 \mu \mathrm{m}$ filtered North Pacific seawater samples of Alibo and Nozaki (1999).

Shale-normalized REE fractionation patterns of Kona Coast groundwaters and coastal seawater are all enriched in the HREEs relative to the LREEs (Figs. 4). The shalenormalized $\mathrm{Yb} / \mathrm{Nd}$ ratios [i.e., $(\mathrm{Yb} / \mathrm{Nd})_{\mathrm{SN}}$, where $\mathrm{SN}=$ shale-normalized], which provides a measure of fractionation across the REE series, are all greater than unity for Kona Coast waters (Table 4). Specifically, the $(\mathrm{Yb} / \mathrm{Nd})_{\mathrm{SN}}$ ratios of the $0.45 \mu \mathrm{m}$ filtered water samples range from 1.25 to 1.74 (mean $\pm \mathrm{SD}=1.57 \pm 0.17$ ), and for the $0.02 \mu \mathrm{m}$ filtered samples, this ratio varies between 1.41 and 1.87 (mean $\pm \mathrm{SD}=1.58 \pm 0.18$ ). The REE patterns of the Kona Coast groundwaters and coastal seawater are also less fractionated than North Pacific seawater (Fig. 4). By comparison, the $(\mathrm{Yb} / \mathrm{Nd})_{\mathrm{SN}}$ ratios for the North Pacific seawater samples analyzed by Alibo and Nozaki (1999) range from 3.49 to 5.29 (i.e., $0.04 \mu \mathrm{m}$ filtered), and exhibit a mean $( \pm \mathrm{SD})$ of $4.49 \pm 0.52$.

Another important feature of the shale-normalized fractionation patterns for Kona Coast water is the substantial positive Gd anomaly of groundwater from the Honokohau Harbor well (Fig. 4). Specifically, the Gd anomaly for the $0.45 \mu \mathrm{m}$ and $0.02 \mu \mathrm{m}$ filtered 
Honokohau Harbor well waters are 5.05 and 6.84, respectively (Table 4). These values exceed the commonly observed positive Gd anomalies of open ocean seawater (e.g., Kim et al., 1991), which ranges, for example, from 1.04 to 1.23 (mean $\pm \mathrm{SD}=1.15 \pm 0.06$ ) in the North Pacific seawater samples analyzed by Alibo and Nozaki (1999). Coastal seawater from Kona also exhibits a positive Gd anomaly that exceeds the reported mean value for North Pacific seawater by between 18 to $28 \%$, based again on the data from Alibo and Nozaki (1999). Positive, shale-normalized Gd anomalies larger than those reported for open ocean seawater are not a characteristic of the other Kona Coast groundwaters.

Normalization of the REE concentrations of Kona Coast waters to shale composites is instructive for comparisons to other natural waters. However, because the local bedrock consists of basalts and their weathering products, a more appropriate normalizing standard is the local basaltic bedrock. Figure 5 presents REE fractionation patterns of Kona Coast groundwaters and coastal seawater normalized to a composite of local basalts. The basalt composite represents the average REE content of alkali, Hualalai basalts $(n=12)$ presented in Hanano et al. (2010). A key feature of Fig. 5 is the generally flat fractionation pattern between La and Dy, and the marked enrichment in REEs heavier than Dy in these groundwaters and the coastal seawater sample compared to the basalts. Positive, basalt-normalized Gd anomalies are apparent for both Honokohau Harbor well water as well as coastal seawater. In addition, all of the Kona Coast waters exhibit negative $\mathrm{Eu}$ and small, positive $\mathrm{Ce}$ anomalies when normalized to the local basalt composite (Fig. 5). 


\subsection{Mixing experiments}

The results of the Honokohau Harbor and Lava Tube mixing experiments for Nd, Gd, and $\mathrm{Yb}$ are presented in Figs. 6 and 7, respectively. Because the REE concentrations of Kona Coast waters filtered through $0.45 \mu \mathrm{m}$ and $0.02 \mu \mathrm{m}$ pore-size filters were not statistically different (Student's $t$-test; $p>0.05$ ), only data for waters filtered through 0.45 $\mu \mathrm{m}$ filters are shown. Nonetheless, the full datasets for these mixing experiments are included in the Appendix (Tables A1, A2).

The REE concentrations in the coastal groundwater endmembers are only slightly enriched (between 1.1 to 2 times) over their concentrations in coastal seawater. The only exception is Gd in the Honokohau Harbor mixing experiment, which is 4.5-fold higher in Honokohau Harbor well water compared to the coastal seawater sample. In general, positive deviations from the conservative mixing line connecting the groundwater endmembers with the coastal seawater sample characterize the majority of the REE data for both mixing experiments. Again, the chief exception is Gd in the Honokohau Harbor mixing experiment, which exhibits a nearly linear dilution trend, indicating conservative behavior (Fig. 6). Gadolinium did not, however, exhibit conservative behavior in the Lava Tube mixing experiment (Fig. 7).

The majority of the REE concentrations for both mixing experiments plot above the conservative mixing line indicating that REEs were released from suspended particles or colloids upon mixing. For the Honohohau Harbor mixing experiment, the greatest REE release occurred at salinities between 7 and 15 where between 22 and $38 \mathrm{pmol} \mathrm{kg}^{-1}$ of $\mathrm{Nd}$ was mobilized (Fig. 6). The greatest release occurred at slightly lower salinities (i.e., 5 to 8) in the Lava Tube mixing experiment where 25 to $35 \mathrm{pmol} \mathrm{kg}^{-1}$ of $\mathrm{Nd}$ was released 
(Fig. 7). Two exceptions occurred for both mixing experiments where the measured REE concentrations plotted below the conservative dilution lines suggesting removal of the REEs. These include the 5.3 and 31.9 salinity samples from the Honokohau Harbor mixing experiments, and the 4.4 and 20.1 salinity samples from the Lava Tube mixing experiment (Tables A1, A2). The relative amount of release generally followed that sequence LREE > MREE > HREE in both mixing experiments, and the overall amounts of REE release were greater in the Honokohau Harbor mixing experiment than for the Lava Tube mixing experiment (Figs. 6, 7).

\subsection{Geochemical modeling}

The results of the solution complexation modeling for REEs in Kona Coast groundwaters and the coastal seawater sample are presented in Fig. 8. The Geochemist's Workbench $^{\circledR}$ software package employs the "B-dot" model to estimate activity coefficients of solutes in solution (Helgeson, 1969). The B-dot model is described in the electronic annex along with a comparison of its performance against a combined specific ion interaction and ion-pairing model.

The speciation model predicts that REEs chiefly occur in Kona Coast groundwaters and coastal seawater as complexes with carbonate ions. Specifically, the dicarbonato complex, $\mathrm{Ln}\left(\mathrm{CO}_{3}\right)_{2}{ }^{-}$, is predicted to predominate for all of the REEs in the Kona Coast groundwaters and coastal seawater. The only exceptions are La and Ce in the Honokohau Harbor well water, where the carbonato complex, $\mathrm{LnCO}_{3}^{+}$, is predicted to account for more (i.e., La) and approximately equal amounts (i.e., Ce) than the dicarbonato complex (Fig. 8). More specifically, the model predicts that between $77 \%$ 
(i.e., La in Honokohau Harbor well water) and $\sim 100 \%$ of each REE occurs as carbonate complexes [i.e., $\mathrm{LnCO}_{3}{ }^{+}+\mathrm{Ln}\left(\mathrm{CO}_{3}\right)_{2}^{-}$] in Kona Coast waters.

Results of the solution complexation modeling for the two mixing experiments are summarized in Figs. 9 and 10. The activity of the free metal ion, $\left[\mathrm{Ln}^{3+}\right]_{F}$, decreases dramatically with increasing salinity in each mixing experiment as progressively more of each REE is complexed with dissolved carbonate ions. The negatively charged dicarbonato complex, [i.e., $\operatorname{Ln}\left(\mathrm{CO}_{3}\right)_{2}^{-}$] is again the chief form of each REE in solution, and the percentage of each REE that occurs as discarbonato complexes increases with increasing salinity, increasing $\mathrm{pH}$, and increasing atomic number (Figs. 9, 10; Tables A1, A2). The results of the solution complexation modeling for the Honokohau Harbor mixing experiment exhibit greater variation than the Lava Tube mixing experiment chiefly because of the greater $\mathrm{pH}$ change across the salinity gradient for the Honokohau Harbor experiment (Tables A1, A2). Specifically, $\mathrm{pH}$ changes from 6.9 to 8.03 for the Honokohau Harbor mixing experiment compared a pH change from 7.7 to 8.03 for the Lava Tube mixing experiment. Hence, greater amounts of each REE are predicted to occur as carbonato complexes [i.e., $\mathrm{NdCO}_{3}{ }^{+} \sim 30-35 \%$; $\mathrm{YbCO}_{3}{ }^{+} \sim 12-13 \%$; ] and free metal ions $\left[\mathrm{Nd}^{3+} \sim 1.5 \% ; \mathrm{Yb}^{3+} \sim 0.2 \%\right]$ in the lower salinity portions of the Honokohau Harbor mixing experiment compared to the Lava Tube mixing experiment. By comparison, $\mathrm{NdCO}_{3}{ }^{+}$and $\mathrm{Nd}^{3+}$ are predicted to account for $\sim 11 \%$ and $0.1 \%$ of total aqueous $\mathrm{Nd}$, and $\mathrm{YbCO}_{3}{ }^{+}$, and $\mathrm{Yb}^{3+}$ for less than $3 \%$ and $0.005 \%$, respectively, of total dissolved $\mathrm{Yb}$ in the low salinity waters of the Lava Tube mixing experiment (Fig. 10).

The results of the solution - surface partitioning model for the REEs in the Honokohau Harbor mixing experiments are presented in Fig. 11. Here the inverse of 
equation 1, [i.e., $\left(D_{\mathrm{Ln}} / D_{\mathrm{Gd}}\right)^{-1}$ ], is plotted as a function of salinity. Hence, values that exceed unity indicate that the particular REE has a greater proclivity for the solution phase compared to Gd at any given salinity (e.g., Byrne and Kim, 1990). Values less than one indicate that the REE has a greater preference for O-donor surface sites on suspended particles or colloids relative to Gd. Again, the partition coefficients are not computed using the REE concentrations measured in the waters, and hence are not influenced by, for example, the anomalously high Gd concentrations of Honokohau Harbor well waters and the mixing experiments performed with this well water. For the Honokohau Harbor mixing experiment, the model indicates that REEs lighter than $\mathrm{Gd}$, such as $\mathrm{La}$ and $\mathrm{Nd}$, exhibit a greater affinity for the solution phase than for surface sites of particles or colloids compared to $\mathrm{Gd}$, but that the preference of the LREEs for the solution phase decreases with increasing salinity and increasing $\mathrm{pH}$ across the mixing gradient. In contrast, REEs heavier than Gd (i.e., Dy, Yb, Lu) prefer to be adsorbed on suspended particles or colloids at lower salinities and lower pH (Fig. 11). Nevertheless, as salinity and $\mathrm{pH}$ increases, HREEs exhibit an increasing affinity for the solution phase such that they are expected to preferentially partition to the solution phase when salinity exceeds 15 and $\mathrm{pH}$ exceeds $\sim 7.5$. Prouty et al. (2016) noted that peak release of colloidal bound phosphate also occurred at a salinity of 15 . For the Lava Tube mixing experiment, the model indicates that all of the REEs exhibit a preference for the solution phase relative to Gd, such that the solution - surface partitioning behavior of the REEs varies little with changing salinity. 


\section{Discussion}

\subsection{REEs in Kona Coast groundwaters}

The nearly identical shale-normalized REE fractionation patterns of Kona Coast groundwaters and the local seawater provides strong evidence that SGD is the chief source of REEs to the coastal ocean (Fig. 4). Furthermore, the positive Eu anomalies that are apparent in REE patterns when Kona Coast groundwaters are normalized to the coastal seawater values (Fig. 12) likely reflect a weathering signature of the local basalts (e.g., Tanaka et al., 2008; Ren et al., 2009; Fröllje et al., 2016). The importance of SGD as the principal source of REEs to the coastal ocean is underscored by the substantially higher REE concentrations of Kona Coast seawater, especially the LREEs, when compared to North Pacific seawater (Fig. 4). Moreover, because the $0.45 \mu \mathrm{m}$ and $0.02 \mu \mathrm{m}$ filtered water samples returned REE concentrations that are statistically indistinguishable from each other based on a two-tailed Student's $t$-test, the data demonstrate that the REEs are either in solution as truly dissolved ionic species or are associated with LMW colloids (i.e., $<0.02 \mu \mathrm{m}$ in diameter). The identical $(\mathrm{Yb} / \mathrm{Nd})_{\mathrm{SN}}$ ratios of the $0.45 \mu \mathrm{m}$ and $0.02 \mu \mathrm{m}$ filtered Kona Coast waters further support this observation.

The relatively large positive Gd anomaly that characterizes the shale-normalized REE pattern of the Kona Coast seawater sample indicates that treated wastewater from the Kealakehe WWTF influences these coastal waters offshore of Honokohau Harbor. Specifically, large positive Gd anomalies commonly reflect anthropogenic Gd that originates from highly stable Gd containing contrast agents, such as Gd-(DPTA) ${ }^{2-}$, that are used in magnetic resonance imaging (Bau and Dulski, 1996). The dissolved Gd$(\text { DPTA })^{2-}$ complex is subsequently transferred to environmental waters via waste water 
treatment facilities with little apparent breakdown during the treatment process (e.g., Bau and Dulski, 1996; Kümmerer and Helmers, 2000; Verplanck et al., 2005). Because the WWTF discharges effluent to an excavated pit located approximately $1 \mathrm{~km}$ up gradient from the Honokohau Harbor well (Parsons et al., 2008), and because groundwater from this well exhibits an even larger positive Gd anomaly, the smaller, albeit significant, positive Gd anomaly observed in Kona seawater can be explained by mixing of local wastewater-impacted SGD with North Pacific seawater. The results of the Honokohau Harbor mixing experiment where Gd behaves conservatively when Honokohau Harbor well waters are mixed with local seawater supports this hypothesis (Fig. 6). Indeed, the Honokohau Harbor mixing experiment confirms that anthropogenic $\mathrm{Gd}$ behaves conservatively during mixing in subterranean estuaries, as previously suggested in field studies of surface estuaries (e.g., Kulaksız and Bau, 2007; Hatje et al., 2016). Therefore, anthropogenic Gd may be a potential tracer of sewage discharge to natural waters, including the coastal ocean.

The Hualalai basalt-normalized REE patterns of Kona Coast groundwaters are relatively flat between La and Dy (Fig. 5). These flat patterns support the notion that chemical weathering of the local basalt is the chief source of REEs to the groundwaters, and hence, to the coastal ocean. Furthermore, the flat basalt-normalized REE patterns of the groundwaters indicate that little fractionation of the LREEs and the MREEs occurs during chemical weathering and dissolution of the Hualalai basalts, and subsequent transport of REEs through the subterranean estuary. In contrast, REEs heavier than Dy (i.e., Ho through $\mathrm{Lu}$ ) are enriched in Kona Coast groundwaters when normalized to the Hualalai basalts compared to the LREEs and MREEs, indicating that the HREEs are 
more mobile during chemical weathering of the local Kona Coast basalts. These observations are consistent with many previous studies of REE behavior during chemical weathering (Nesbitt, 1979; Duddy, 1980; Braun et al., 1990, 1993; Nelson et al., 2004).

The origin of the REE fractionation patterns of Kona Coast groundwaters can be understood by considering the following conceptual model. When local rainwater $(\mathrm{pH}$ 4.8; Eriksson, 1957; Berner and Berner, 2012) infiltrates the Hualalai basalts, its acidity is sufficient to corrode the volcanic glass that dominates these basalts as well as any phenocryst minerals (e.g., olivine), releasing REEs into solution. The relative distribution (i.e., fractionation pattern) of the REEs in the initial weathering solution/groundwater will likely resemble the fractionation pattern of the bulk rock, or more specifically, the dominant basaltic glass component of these basalt flows (e.g., Price et al., 1991). Secondary minerals formed during low-temperature chemical weathering of basaltic glass (e.g., clay minerals, Fe/Mn oxides/oxyhydroxides, and especially rhabdophane) preferentially capture the LREEs, and to a lesser extent, the MREEs, that are mobilized during weathering compared to the HREEs, which are more stable in solution as carbonate complexes (Humphris, 1984; Eggleton et al., 1987; Price et al., 1991; Fodor et al., 1992a, b, 1994; Gillis et al., 1992; Nesbitt and Wilson, 1992; Daux et al., 2004; Cotton et al., 1995; Stefánsson and Gíslason, 2001; Ziegler et al., 2003). As chemical weathering proceeds, bicarbonate ions are produced and $\mathrm{pH}$ rises, as does the concentrations of dissolved carbonate ions. Together, these processes act to preferentially sequester LREEs and MREEs by adsorption onto, or uptake within, secondary minerals, whereas the HREEs are preferentially mobilized from sites of active weathering by strong complexing ligands like carbonate ions and subsequently 
transported, as dissolved complexes, with flowing groundwater (Ronov et al., 1967; Aagaard, 1974; Nesbitt, 1979; Duddy, 1980; Braun et al., 1990, 1993; Johannesson et al., 1999; 2005; Tang and Johannesson, 2010a). Comparable arguments have been advanced to explain the similar input-normalized REE fractionation patterns of groundwaters from the Wanapum Basalt aquifer in northern Idaho and eastern Washington (Nelson et al., 2004).

The enrichment of the HREEs in the Kona Coast groundwaters compared to the basaltic aquifer rocks is consistent with the conceptual model as well as the results of the solution complexation modeling, which predicts that HREEs chiefly occur in these groundwater as highly stable, negatively charged dicarbonato complexes, $\mathrm{Ln}\left(\mathrm{CO}_{3}\right)_{2}^{-}$(Fig. 8). In contrast, substantial amounts of the LREEs (e.g., more than $40 \%$ and $8 \%$ of $\mathrm{La}$ in Honokohau Harbor Well waters) are predicted to occur in solution as positively charged carbonato complexes, $\mathrm{LnCO}_{3}{ }^{+}$, and free metal ions, $\mathrm{Ln}^{3+}$, respectively (Fig. 8). Because the stability constants describing the formation of dissolved REE carbonato and dicarbonato complexes increase by more than 10- and 117-fold, respectively, with increasing atomic number across the REE series (Luo and Byrne, 2004), the HREEs form stronger aqueous carbonate complexes than either the LREEs or MREEs. The formation of strong aqueous complexes lowers the activity of the free metal ion, which inhibits surface complexation of the HREEs onto - or uptake within - secondary minerals like metal oxides/oxyhydroxides, compared to the LREEs, and to a lesser degree, the MREEs, during weathering and subsequent transport of the REEs through the coastal basalt aquifers (Byrne and Kim, 1990; Koeppenkastrop and De Carlo, 1992, 1993; Quinn et al., 2004, 2006; Tang and Johannesson, 2005). We note that estimates of the point of zero net 
proton charge for Hawaiian basalts are less than 6.2 and 5.8 for 0.001 and 0.01 molar solutions, respectively (Chorover et al., 2004), suggesting that in addition to free metal ions, REE carbonato complexes, but not dicarbonato complexes, will also adsorb onto surfaces of the local basalt aquifer. Consequently, the HREEs are predicted to be more mobile in the Kona Coast groundwater system compared to the MREEs, and especially the LREEs.

\subsection{Mixing experiments}

The results of the Kona Coast mixing experiments differ dramatically from similar experiments involving river waters. Specifically, substantial removal of REEs from solution is commonly reported in laboratory experiments in which river water is mixed with seawater, with the majority of the REEs being removed at low salinity (i.e., 0 to 10; Hoyle et al., 1984; Sholkovitz, 1995). In contrast, the REEs were released into solution when Kona Coast groundwaters were mixed with local seawater (Figs. 6, 7). It should be noted that in the mixing experiments conducted by Sholkovitz (1995) the water samples were filtered through $0.22 \mu \mathrm{m}$ filters prior to mixing, whereas in our experiments, the water samples were mixed prior to filtration. Consequently, our experiments are more akin to those of Hoyle et al. (1984) in which river water filtered through $18 \mu \mathrm{m}$ pore-size filters were mixed with seawater that had been filtered through 5 $\mu \mathrm{m}$ pore-size filters. Consequently, because we mixed Kona Coast groundwaters with seawater prior to filtration, suspended particulate matter, as well as colloids, were available to coagulate, flocculate, and remove REEs from solution. Nevertheless, the 
Kona Coast mixing experiments induced mobilization of REEs to the dissolved phase instead of removal (Figs. 6, 7).

The loss of REEs from solution observed in earlier laboratory investigations that employed river waters was ascribed to salt-induced coagulation and flocculation of $\mathrm{Fe}$ rich, organic colloids at low salinity, which scavenged the REEs and other trace metals from solution, and then settled out of suspension (Sholkovitz, 1976, 1993, 1995; Boyle et al., 1977, 1982; Sholkovitz and Copland, 1981; Hoyle et al., 1984). Transects through a number of surface estuaries also reveal substantial removal of REEs from solution in the low salinity regions where river water initially encounters seawater, in agreement with the bottle mixing experiments discussed above (e.g., Martin et al., 1976; Goldstein and Jacobsen, 1988a; Sholkovitz and Elderfield, 1988; Elderfield et al., 1990; Sholkovitz, 1993, 1995; Sholkovitz and Szymczak, 2000; Lawrence and Kamber, 2006; Censi et al., 2007; Åström et al., 2012; Rousseau et al., 2015). Again, the same mechanism of saltinduced coagulation and flocculation of Fe-rich, organic colloids, can explain REE removal from the water column in the low salinity region of these surface water estuaries. It should be noted that a number of field-based estuarine studies have also reported release of REEs back to the water column at mid to high salinities (i.e., salinity $>20$ ), although the fraction of REEs released back to solution is generally small compared to the amount removed in the low salinity region of the estuary (e.g., Sholkovitz, 1995; Sholkovitz and Szymczak, 2000; Lawrence and Kamber, 2006). The release of REEs in the mid to high salinity region of estuaries likely reflects diagenetic processes occurring in estuary sediments and associated porewaters such as reductive dissolution of $\mathrm{Fe}(\mathrm{III}) / \mathrm{Mn}(\mathrm{IV})$ oxides/oxyhydroxides and subsequent release of sorbed or co-precipitated 
REEs, remineralization of organic matter containing sorbed/complexed REEs, and/or displacement of REEs from mineral surfaces by marine salts (Elderfield and Sholkovitz, 1987; Sholkovitz et al., 1989, 1992; Haley et al., 2004). Release of REE in the Kona Coast subterranean estuary mixing experiments occurs as substantially lower salinities (7 - 8) compared to the mid to high salinities where REE release is reported to occur in surface estuaries (> 20; Sholkovitz and Szymczak, 2000).

A possible explanation of the REE behavior in the Kona Coast mixing experiment may be related to the fact that these coastal groundwaters are brackish and not fresh (Table 2), and consequently REEs were previously removed from solution further up gradient in the subterranean estuary where fresh groundwater first encounters recirculating seawater. In this case, fresh Kona Coast groundwater (i.e., salinity $\sim 0$ ) would be expected to exhibit higher REE concentrations than the nearshore, brackish groundwaters analyzed here. However, a number of features of the Kona Coast subterranean estuary argue against this possibility. First, other than Gd in the Honokohau Harbor well, there is relatively little difference in the REE concentrations of the Kona Coast groundwater samples despite their range in salinity. For example, notwithstanding the fact that groundwater from the KAHO 3 well is 6-fold more saline, exhibits a $\mathrm{Cl}$ concentration that is 6 times higher, and an ionic strength that is a factor of 3.6 greater than groundwater from the Hind (i.e., Lava tube) well, the Nd concentration of the fresher Hind well groundwater is only 1.2 times higher than in the more saline KAHO 3 well groundwater (Tables 2, 4). Moreover, the Nd concentration of the fresher groundwater from the Hind well is less than a factor of 1.1 higher than $\mathrm{Nd}$ in the Honokohau Harbor well groundwater, regardless of the fact that the latter groundwater is 2.4 times more 
saline. Furthermore, Tillman et al. (2014a) recently reported concentrations for some REEs in groundwaters from the Kona Coast, including fresh (salinity $\sim 0$ ), groundwaters from wells that are up gradient from the brackish nearshore groundwaters we sampled. Although Tillman et al. (2014a) do not report data for the majority of the REEs, they do present concentrations for $\mathrm{La}$ (mean \pm standard deviation $=8.8 \pm 5.5 \mathrm{pmol} \mathrm{kg}^{-1}, \mathrm{n}=3$ ), Ce $\left(\right.$ mean $\left.=21 \mathrm{pmol} \mathrm{kg}^{-1}, \mathrm{n}=2\right)$, and $\operatorname{Pr}\left(\right.$ mean $\left.=27.6 \mathrm{pmol} \mathrm{kg}^{-1}, \mathrm{n}=2\right)$ for fresh Kona Coast groundwaters. The La and Ce concentrations of these fresh groundwaters are, on average, 16-fold lower than in the nearshore, brackish Kona Coast groundwaters, and $\operatorname{Pr}$ is nearly 1.5 times lower in the fresh groundwaters (Table 4). Taken together, these observations, and the fact that the nearshore Kona Coast groundwaters exhibit similar REE concentrations to the coastal seawater (Fig. 4), indicate that large-scale removal of REEs, which characterizes the behavior of the REEs in the low salinity region of many surface estuaries, is not a feature of the subterranean estuary along the Kona Coast.

The lack of removal of REEs from solution in the Kona Coast mixing experiments, and by inference, the Kona Coast subterranean estuary, instead likely reflects the much lower dissolved organic carbon concentrations, as well as the lower dissolved $\mathrm{Fe}$ and $\mathrm{Mn}$ concentrations, of these groundwaters compared to previously studied rivers and associated surface estuaries that exhibit REE removal (Table 3). For example, DOC concentrations are between 4 and 21 times greater in these rivers and their associated estuaries than in Kona Coast groundwaters, excluding groundwater from the Honokohau Harbor well, which again receives effluent from the WWTF (e.g., Parsons et al., 2008; Hunt, 2014; Prouty et al., 2016; Table 3). Dissolved Fe concentrations in these rivers and surface estuaries are also commonly between 2- and 5-fold higher than in Kona 
Coast groundwaters (Tables 2, 3). In fact, the Kona Coast groundwaters have $\mathrm{Fe}$ concentrations that are either identical to the coastal seawater sample (i.e., $11.6 \mathrm{nmol} \mathrm{kg}{ }^{-}$ ${ }^{1}$ ) or below detection (i.e., $<3 \mathrm{nmol} \mathrm{kg}{ }^{-1}$; Table 2). The one exception is groundwater from the KAHO 2 well, which has a Fe concentration of $62.5 \mathrm{nmol} \mathrm{kg}{ }^{-1}$. The low DOC and Fe concentrations that characterize Kona Coast groundwaters likely inhibit saltinduced flocculation and coagulation, and hence REE removal, when the groundwater mixes with seawater in local subterranean estuaries. The low DOC concentrations of Kona Coast groundwaters reflect the arid climate and sparse surface vegetation of this leeward desert, whereas the low $\mathrm{Fe}$ and $\mathrm{Mn}$ concentrations are explained by the oxic nature of these groundwaters $\left(83.4 \mu \mathrm{mol} \mathrm{kg}{ }^{-1} \leq \mathrm{DO} \leq 252 \mu \mathrm{mol} \mathrm{kg}{ }^{-1}\right.$; Table 2$)$, and their relatively short groundwater residence times in the aquifer ( 30 years; Kelly and Glenn, 2015). We note that Hoyle et al. (1984) also reported no detectable REE loss across the salinity gradient in the organic matter-poor Wharfe River estuary in the United Kingdom.

The release of REEs to solution in the mixing experiments reflects a combination of processes that are related to changes in REE solution complexation across the salinity gradients in each experiment (Figs. 9, 10). These changes are chiefly driven by increasing $\mathrm{pH}$, which leads to increases in the concentrations of carbonate ions, $\left[\mathrm{CO}_{3}{ }^{2-}\right]$, and to a lesser extent by the salinity increase that accompanies mixing of the terrestrial groundwaters with coastal seawater. The effect of increasing $\mathrm{pH}$ and changing solution composition is to increase the amount of each REE in solution that is complexed to strong dissolved ligands, namely carbonate ions [i.e., $\mathrm{LnCO}_{3}{ }^{+}, \mathrm{Ln}\left(\mathrm{CO}_{3}\right)_{2}{ }^{-}$, which concomitantly decreases the amount of each REE in solution that occurs as free metal ions, $\mathrm{Ln}^{3+}$ (Figs. 9, 10). The decrease in free metal ion activity across the mixing gradient 
helps drive REE desorption from suspended particles or colloids during mixing (Figs. 9, 10; Comans and van Dijk, 1988). Hence, the lower $\mathrm{pH}$ of Honokohau Harbor well water (pH 6.9) compared to groundwater from the Hind well ( $\mathrm{pH}$ 7.7) explains, in part, the greater release of REEs in general, and the LREEs in particular, in the lower salinity samples from the Honokohau Harbor mixing experiment compared to the Lava Tube mixing experiment. The predicted predominance of aqueous REE dicarbonato complexes across the salinity gradient of both mixing experiments (Figs. 9, 10) further inhibits REE adsorption, and instead promotes desorption of REEs from suspended particles or colloids in these mixed solution (e.g., Tang and Johannesson, 2005).

Increasing salinity also likely plays a role in the release of REEs from suspended particles or colloids during mixing. More specifically, increases in the concentrations of competing cations, namely $\mathrm{Mg}^{2+}$ and $\mathrm{Ca}^{2+}$, that accompanies increasing salinity can promote desorption of REEs (Tang and Johannesson, 2005, 2010b). Moreover, competitive sorption reactions are commonly more important at low $\mathrm{pH}$ where these reactions affect the LREEs to a greater extent than either the MREEs or HREEs (Tang and Johannesson, 2005, 2010b).

The results of the solution - surface partition model for the REEs are also generally in agreement with the observations of the mixing experiments. For example, the partition model suggests that the LREEs exhibit a greater affinity for the solution phase at lower salinities in the Honokohau Harbor mixing experiment compared to the MREEs and HREEs, which is also observed in the mixing experiment. The greater affinity of the LREEs for the solution phase predicted for the Honokohau Harbor mixing experiment compared to the Lava Tube mixing experiment can again be explained by the lower $\mathrm{pH}$ 
of the endmember groundwater (Honokohau Harbor well water, $\mathrm{pH}$ 6.9) compared to the Hind well $(\mathrm{pH}$ 7.7). The partition model results are consistent with the notion that relatively more of the REEs in general, and the LREEs in particular, are released from suspended particles or colloids in the Honokohau Harbor mixing experiment as $\mathrm{pH}$ increases and the formation of strong aqueous, dicarbonato complexes become progressively more abundant. In contrast, because groundwater from the Hind well is nearly a whole $\mathrm{pH}$ unit higher than Honokohau Harbor well water, the majority of surface bound REEs have already been stripped from suspended particles or colloids by formation of aqueous REE dicarbonato complexes. As a consequence the partition model predicts only small variations in the partitioning behavior of the REEs across the salinity gradient for the Lava Tube mixing experiment.

\subsection{Submarine groundwater discharge fluxes}

The groundwater flux of REEs to the ocean along the Kona Coast is estimated using the volumetric SGD fluxes determined by Peterson et al. (2009), and assuming that the behavior of the REEs in the mixing experiments is representative of their behavior in Kona Coast subterranean estuaries. The SGD fluxes from Peterson et al. (2009) are employed because these researchers investigated SGD at both Honokohau Harbor, as well as at Kiholo Bay, which corresponds with our Lava Tube mixing experiments, hence, providing a consistent set of SGD estimates for our two study sites.

To model REE release across the salinity gradient at the Honokohau Harbor and Kiholo Bay sites, we employ the method developed by Li and Chan (1979) for trace elements that behave nonconservatively in estuarine systems. The approach follows from 
the work of Boyle et al. (1977), Hanor and Chan (1977), and Officer (1979), whereby the release rate of a particular nonconservative trace element is estimated by constructing a chord or a tangent line from the ocean endmember through the highest salinity point(s) on the nonconservative trace element concentration versus salinity distribution curve for the estuary, or in our case, the salinity gradient of the mixing experiment ( $\mathrm{Li}$ and Chan, 1979; Maeda and Windom, 1982; Swarzenski et al., 1995). Commonly, the tangent line is approximated by linear regression from the ocean endmember through the more saline water samples and back to 0 salinity (Li and Chan, 1979; Swarzenski et al., 1995; Nozaki et al., 2001). The resulting $y$-intercept of the tangent line, or computed linear regression line, is an estimate of the effective terrestrial water endmember concentration of the nonconservative trace element ( $\mathrm{Li}$ and Chan, 1979; Head, 1985, and references therein). For the Kona Coast subterranean estuaries, the resulting $y$-intercept is the effective freshwater endmember concentration of the particular REE.

The model assumes steady state conditions, which implies mass balance equations for water, salts, and the nonconservative species of interest (Li and Chan, 1979). For the water balance, we have

$$
\mathrm{Q}_{\mathrm{TotSGD}}=\mathrm{Q}_{\mathrm{TSGD}}+\mathrm{Q}_{\text {MarineSGD }}
$$

in which $\mathrm{Q}_{\mathrm{TSGD}}$ and $\mathrm{Q}_{\text {MarineSGD }}$ are the terrestrial and marine SGD $\left(\mathrm{m}^{3}\right.$ day $\left.^{-1}\right)$, which when combined, gives the total SGD flux, $\mathrm{Q}_{\text {TotSGD }}$ (e.g., Martin et al., 2007; Johannesson et al., 2011). The salt mass balance, written in terms of the salinity, $S$, is

$$
\mathrm{Q}_{\mathrm{TotSGD}} S_{\mathrm{TotSGD}}=\mathrm{Q}_{\mathrm{TSGD}} S_{\mathrm{TSGD}}+\mathrm{Q}_{\text {MarineSGD }} S_{\text {MarineSGD }}
$$


where $S_{\text {TotSGD }}, S_{\mathrm{TSGD}}$, and $S_{\text {MarineSGD }}$ represent the salinity of the total SGD, the terrestrial sourced SGD, and the marine sourced SGD fluxes. The mass balance for each REE is then given by

$$
\mathrm{Q}_{\mathrm{TotSGD}}[\mathrm{Ln}]_{\mathrm{TotSGD}}=\mathrm{Q}_{\mathrm{TSGD}}[\mathrm{Ln}]_{\mathrm{TSGD}}+\mathrm{Q}_{\text {MarineSGD }}[\mathrm{Ln}]_{\text {MarineSGD }}+\boldsymbol{J}_{\mathrm{des} \text { erb }}^{[\mathrm{Ln}]}
$$

where $[\mathrm{Ln}]_{\text {TotSGD }},[\mathrm{Ln}]_{\mathrm{TSGD}}$, and $[\mathrm{Ln}]_{\text {MarineSGD }}$ are the individual REE concentrations in the total, terrestrial sourced, and marine sourced SGD, and $\boldsymbol{J}_{\mathrm{desorb}}^{[\mathrm{Ln}]}$ is the desorption (i.e., release rate) flux of each individual REE from suspended particles or colloids to solution (e.g., Li and Chan, 1979; Swarzenski et al., 1995). Combining equations 3 through 5, and rearranging yields

$$
[\mathrm{Ln}]_{\mathrm{TSGD}}+\frac{J_{\mathrm{desorb}}^{[\mathrm{Ln}]}}{\mathrm{Q}_{\mathrm{TSGD}}}=[\mathrm{Ln}]_{\mathrm{TotSGD}}-\left(S_{\mathrm{TotSGD}}-S_{\mathrm{TSGD}}\right) \frac{[\mathrm{Ln}]_{\mathrm{TotSGD}}-[\mathrm{Ln}]_{\mathrm{MarineSGD}}}{S_{\mathrm{TotSGD}}-S_{\text {MarineSGD }}},
$$

or, more simply

$$
[\mathrm{Ln}]_{\mathrm{TSGD}}+\frac{J_{\mathrm{des} o r b}^{[\mathrm{Ln}]}}{\mathrm{Q}_{\mathrm{TSGD}}}=[\mathrm{Ln}]_{\mathrm{TotSGD}}-\left(S_{\mathrm{TotSGD}}-S_{\mathrm{TSGD}}\right) \frac{\Delta[\mathrm{Ln}]}{\Delta S},
$$

where the left hand side of equation 6 is the effective terrestrial SGD concentration for any given REE, which again represents the $y$-intercept of the tangent line described above (Li and Chan, 1979; Head, 1985; Swarzenski et al., 1995).

Constructing a tangent line to determine the maximum release for each REE in our mixing experiments is difficult because the data commonly exhibit multiple peaks and troughs (Figs. 6, 7). Moreover, models for desorbing, nonconservative trace elements (e.g., Hanor and Chan, 1977) imply that plots of trace element concentrations versus salinity may be persistently concave-down - that is, there may be no straight-line region of the trend from which to construct the dilution line as is commonly recommended (Boyle et al., 1974). However, these issues can be approached statistically, whereby the 
trace element concentration variations across the salinity gradient can be modeled using a bootstrap (see electronic annex and Fig. EA3 for details), which approximates plausible sampling distributions by drawing with replacement (Efron and Tibshirani, 1986). The nonlinear character of the REE concentration versus salinity curves (e.g., Figs. 6 and 7) can be modeled using local regressions or loess fits to each of the bootstrap samples (see electronic annex; Cleveland et al., 1992). The loess fit can then be scanned to find the point $\left(S,[\mathrm{Ln}]_{\mathrm{aq}}\right)$ for which $\frac{[\mathrm{Ln}]_{\mathrm{aq}}^{\text {Marine }}-[\mathrm{Ln}]_{\mathrm{aq}}}{S^{\text {Marine }}-S}$ is maximized. This point represents the point of maximum desorption/release of the REE in the mixing experiment, which can occur anywhere between the two endmembers. Here, $[\mathrm{Ln}]_{\mathrm{aq}}^{\text {Marine }}$ is the concentration of the particular REE in the ocean endmember sample and $S^{\text {Marine }}$ is the salinity of the ocean endmember, whereas $[\mathrm{Ln}]_{\mathrm{aq}}$ and $S$ are the REE concentration and salinity value for any sample between the terrestrial and ocean endmembers.

The statistical analysis of the mixing experiment data was implemented in statistical software (R Core Team, 2015). The bootstrap procedure was modified so that the endmembers of the mixing experiments are always included in the sample, and the loess fit is forced through the endmembers (Fig. EA3 in the electronic annex). For each bootstrap sample, estimated errors at each measured sample point (including endmembers) were added to the measurements. A large bootstrap sample $\left(10^{4}\right)$ yielded stable estimates of the effective terrestrial groundwater endmember (i.e., salinity of zero) REE concentration $\left(y\right.$-intercept $\left.=[\mathrm{Ln}]_{\mathrm{TSGD}}+\frac{J_{\mathrm{desorb}}^{[\mathrm{Ln}]}}{\mathrm{Q}_{\mathrm{TSGD}}}\right)$, along with its nonparametric distributions (Figs. 13 and EA3). Distributions can also be computed for the desorptiondilution line and the measurements per se (see Fig. 13). 
Application of the model to $\mathrm{Nd}$ is shown in Fig. 13 for both the Honokohau Harbor and Lava Tube mixing experiments. Results for the other 13 REEs for both the Honokohau Harbor and Lava Tube mixing experiments are presented in the Figs. EA4 through EA17 in the electronic annex. The orange-brown curved line shows the median loess fit to the measured $\mathrm{Nd}$ concentrations, and the orange-brown field represents the 95\% confidence interval for the loess fit to the data. Likewise, the dark blue straight line constructed from the ocean endmember to salinity of zero, the corresponding $y$-intercept, is the median of the bootstrap sample for the tangent line of these data, whereas the light blue triangular field is the $95 \%$ confidence interval. That is, the effective terrestrial groundwater $\mathrm{Nd}$ concentrations for the mixing experiment data should fall within the range of potential $y$-intercepts shown on Fig. 13 with 95\% confidence, with the median effective terrestrial groundwater $\mathrm{Nd}$ concentration of the bootstrap depicted as the blue circle. The inferred distributions of the effective terrestrial groundwater REE concentrations are commonly skewed (Figs. EA18 - EA31), which motivated the use of nonsymmetric confidence intervals along with the median as a point estimate.

Combining the terrestrial groundwater discharge fluxes for Honokohau Harbor $\left(8600 \mathrm{~m}^{3}\right.$ day $\left.^{-1}\right)$ and Kiholo Bay $\left(6300 \mathrm{~m}^{3}\right.$ day $\left.^{-1}\right)$ from Peterson et al. (2009), with our computed estimates of the effective terrestrial groundwater REE concentrations determined as shown above for Nd, and the other 13 REEs in Figs. EA4 - EA17 in the electronic annex, provides estimates of the total SGD fluxes of REEs to the coastal ocean at Honokohau Harbor and Kiholo Bay (Tables 5 and 6). For example, in the case of Nd, we estimate that the total SGD flux of Nd to the coastal ocean ranges between $1909 \mu \mathrm{mol}$ day $^{-1}$ and ca. $2590 \mu \mathrm{mol} \mathrm{day}^{-1}$ (median ca. $2200 \mu \mathrm{mol} \mathrm{day}^{-1}$ ) in the vicinity of Honokohau 
Harbor, and between $1290 \mu \mathrm{mol}$ day $^{-1}$ and $1700 \mu \mathrm{mol}$ day $^{-1}$ (median ca. $1450 \mu \mathrm{mol}$ day $^{-1}$ ) at Kiholo Bay (Tables 5 and 6). The desorption flux, or release rate, of $\mathrm{Nd}$ during mixing in the subterranean estuary is estimated to range from $370 \mu \mathrm{mol} \mathrm{day}^{-1}$ to $1050 \mu \mathrm{mol}$ day $^{-1}$ (median ca. $660 \mu \mathrm{mol}$ day $^{-1}$ ) at Honokohau Harbor, and from $82 \mu \mathrm{mol}$ day $^{-1}$ to $490 \mu \mathrm{mol}$ day $^{-1}$ (median ca. $239 \mu \mathrm{mol}$ day $^{-1}$ ) at Kiholo Bay. Hence, the Nd desorption flux represents between $19 \%$ and $41 \%$ (median ca. 30\%) of the total SGD flux of $\mathrm{Nd}$ to the coastal ocean near Honokohau Harbor, and between $6.3 \%$ and $29 \%$ (median $=16.5 \%$ ) of the total SGD flux of $\mathrm{Nd}$ at Kiholo Bay. Consequently, our estimates suggest that REE release from suspended particles or colloids in subterranean estuaries along the Kona Coast represents a significant fraction of the total groundwater flux of REEs to the coastal ocean. Field-testing by sampling groundwaters from wells/piezometers constructed along a salinity gradient will be necessary to verify whether REE release from suspended particles or colloids upon mixing of groundwater and seawater is characteristic of Kona Coast subterranean estuaries.

The SGD fluxes of the REEs estimated for the Kona Coast are of the same order of magnitude as our recent estimates for SGD fluxes of REEs to the coastal ocean in Rhode Island and Florida (Chevis et al., 2015a, b). Specifically, Chevis et al. (2015b) estimated a SGD flux of Nd of $26 \pm 11 \mathrm{mmol} \mathrm{day}^{-1}$ in the vicinity of the Pettaquamscutt River estuary in Rhode Island, and Chevis et al. (2015b) computed a SGD flux for Nd to the Indian River Lagoon in Florida of $9.4 \pm 1 \mathrm{mmol} \mathrm{day}^{-1}$. Again, our best estimate of the SGD flux of Nd to the coastal ocean near Honokohau Harbor is $2.2 \mathrm{mmol} \mathrm{day}^{-1}$, whereas at Kiholo Bay, our best estimate is $1.4 \mathrm{mmol} \mathrm{day}^{-1}$ of $\mathrm{Nd}$ delivered to the coastal ocean via SGD (Tables 5, 6). The SGD fluxes of the REEs to the coastal ocean in the vicinity of 
the Pettaquamscutt River estuary in Rhode Island and the Indian River Lagoon in Florida are also of similar magnitude to the estimated surface water influxes to both systems (36 mmol day ${ }^{-1}$ and $7.7 \pm 1 \mathrm{mmol} \mathrm{day}^{-1}$, respectively; Chevis et al., 2015a, b). Although no streams discharge to the ocean along the studied portion of the Kona Coast, the slightly lower SGD fluxes of the REEs to these coastal waters (e.g., when compared to the Pettaquamscutt River estuary and Indian River Lagoon) are sufficient to overwhelm background seawater REE concentrations, which results in REE concentrations that are ca. 10-fold higher, and as much as 50-fold higher than REE concentrations measured in North Pacific surface waters. These observations suggest that even arid regions of oceanic islands can generate SGD fluxes of the REEs that represent the major source of these trace elements to the proximal ocean (see also Fröllje et al., 2016). Our results support previous investigations at Jeju Island, South Korea, where SGD fluxes of REEs also appear to comprise the primary material flux of these trace elements to coastal waters (Kim and Kim, 2011, 2014).

\section{Conclusions}

The similarity in the REE fractionation patterns between the Kona Coast groundwater and coastal seawater, the 10- to 50-fold enrichment in REEs concentrations of Kona Coast seawater over open-ocean, North Pacific seawater, and the lack of surface streams along the Kona Coast, all point to SGD being the chief source of REEs to the coastal ocean along the Kona Coast of the Big Island of Hawaii. This notion is further supported by the nearly identical shale-normalized REE pattern of local groundwaters

and seawater, which are markedly flatter than the shale-normalized REE patterns of 
North Pacific seawater. Treated wastewaters from a local wastewater treatment facility (WWTF) can also be traced from nearshore well waters into the coastal ocean by means of large positive Gd anomalies, which further supports SGD as the chief source of REEs to these coastal waters. Normalization of the groundwater REE concentrations to the REE content of local Hualali basalt flows indicate that chemical weathering of these basalts is the primary source of REEs to the groundwater, and hence, coastal ocean, and that dissolved HREE concentrations are enhanced relative to the basalts by formation of strong solution complexes with dissolved carbonate ions. Sequential filtration of the groundwaters through $0.45 \mu \mathrm{m}$ and then $0.02 \mu \mathrm{m}$ filters returns statistically indistinguishable REE concentrations indicating that dissolved REEs are transported in Kona groundwaters to the ocean as "truly dissolved" ionic species or low molecular weight colloids.

Laboratory mixing experiments reveal that the REEs are released from suspended particles or colloids to solution when Kona Coast groundwaters are mixed with local seawater. The lack of REE removal from solution in the mixing experiments, and hence, by inference, Kona Coast subterranean estuaries, is attributed to the low DOC and Fe concentrations of the local groundwater. This finding differs from observations of the behavior of REEs in many surface estuaries where REEs are removed to a large degree from solution where river waters first mix with seawater. Geochemical modeling indicates that REE release to solution in the mixing experiments is driven by increases in $\mathrm{pH}$, decreasing free metal ion activity, and the concomitant formation of strong, aqueous REE dicarbonato complexes [i.e., $\mathrm{Ln}\left(\mathrm{CO}_{3}\right)_{2}{ }^{2}$ ]. Formation of REE dicarbonato complexes accounts for progressively more of each REE as $\mathrm{pH}$ and salinity increases. These strong 
aqueous complexes outcompete adsorption for the REEs, and hence facilitate release of REEs to the solution phase. Rare earth element release is also likely enabled by competition from more abundant cations (e.g., $\mathrm{Mg}^{2+}, \mathrm{Ca}^{2+}$ ) for solid phase surface sites as salinity increases, which can displace sorbed REEs from suspended particles or colloids.

Estimates of REE fluxes to the coastal ocean via SGD (i.e., $1.3-2.6 \mathrm{mmol} \mathrm{Nd}$ day $^{-1}$ ) are of similar magnitude to our recent estimates for SGD fluxes of REEs to the Indian River Lagoon in Florida, and to Rhode Island Sound in the vicinity of the Pettaquamscutt River estuary. Our investigation of the Kona Coast, in conjunction with our previous studies of subterranean estuaries beneath the Indian River Lagoon and the Pettaquamscutt River estuary, all indicate that SGD is an important source of REEs to the coastal ocean. Moreover, our research, along with recent studies in Korean (Kim and Kim, 2011, 2014), are consistent with SGD being an important, albeit, previously unrecognized component of the global oceanic REE budget.

\section{Acknowledgements}

This project was supported by NSF grants OCE-0825920 to Johannesson and OCE-0825895 to Burdige, as well as USGS Natural Resources Preservation Program (NRPP) and Park Oriented Biological Support (POBS) Award to Prouty. The authors wish to thank C. H. Conaway at the U.S. Geological Survey in Menlo Park, California, for the ion chromatography analyses of the anion concentrations, and D. Gross and S. Beavers (NPS) for logistical support. The lead author is indebted to Michael and Mathilda Cochran for endowing the Cochran Family Professorship in Earth and Environmental Sciences at Tulane University. We thank two anonymous reviewers and 
the associate editor Jerôme Gaillardet whose comments greatly improved this paper. This paper is dedicated to the memory of Lutetium Johannesson.

\section{References}

Aagaard P. (1974) Rare earth element adsorption on clay minerals. Bull. Group. Franc. Argiles 26, 193-199.

Adams W. M. and Lepley L. K. (1968) Infrared images of the Kau and Puna coastlines on Hawaii. Water Resources Research Center, University of Hawaii at Manoa, Tech. Rept. No. 26, HIG Series, HIG-WRRC-2, Honolulu, 15 p.

Alibo D. S. and Nozaki Y. (1999) Rare earth elements in seawater: Particle association, shale-normalization, and Ce oxidation. Geochim. Cosmochim. Acta 63, 363-372.

Arsouze T., Dutay J.-C., Lacan F. and Jeandel C. (2009) Reconstructing the Nd oceanic cycle using a coupled dynamical-biogeochemical model. Biogeosci. Discuss. 6, $5549-5588$.

Åström M. E., Österholm P., Gustaffson J. P., Nystrand M., Peltola P., Normmyr L., and Boman A. (2012) Attenuation of rare earth elements in a boreal estuary. Geochim. Cosmochim. Acta 96, 105-119.

Balistrieri L., Brewer P. G., and Murray J. W. (1981) Scavenging residence times of trace metals and surface chemistry of sinking particles in the deep ocean. Deep-Sea Res. 28A, 101-121.

Bau M. and Dulski P. (1996) Anthropogenic origin of positive gadolinium anomalies in river waters. Earth. Planet. Sci. Lett. 143, 245-255.

Berner E. K. and Berner R. A. (2012) Global Environment: Water, Air, and Geochemical 
Cycles. $2^{\text {nd }} e d$. Princeton University Press, Princeton, NJ, 444 p.

Bertram C. J. and Elderfield H. (1993) The geochemical balance of the rare earth elements and neodymium isotopes in the oceans. Geochim. Cosmochim. Acta 57, 1957-1986.

Bethke C. M. (2008) Geochemical and Biogeochemical Reaction Modeling, $2^{\text {nd }}$ ed. Cambridge University Press, Cambridge, UK (543 pp.)

Bethke C. M. and Yeakel S. (2013) The Geochemist's Workbench ${ }^{\circledR}$, Release 9.0. GWB Essentials Guide. Aqueous Solutions, LLC., Champaign, IL (130 pp.)

Bienfang P. (1980) Water quality characteristics of Honokohau Harbor: A subtropical embayment affected by groundwater intrusion. Pac. Sci. 34, 279-291.

Boyle E. A., Collier R., Dengler A. T., Edmond J. M., Ng A. C., and Stallard R. F. (1974) On the chemical mass-balance in estuaries. Geochim. Cosmochim. Acta 38, 17191728.

Boyle E. A., Edmond J. M., and Sholkovitz E. R. (1977) The mechanism of iron removal in estuaries. Geochim. Cosmochim. Acta 41, 1313-1324.

Boyle E. A., Huested S. S., and Grant B. (1982) The chemical mass balance of the Amazon Plume - II. Copper, nickel, and cadmium. Deep-Sea Res. 11A, 13551364.

Braun J. J., Pagel M., Muller J. P., Bilong P., Michard A., and Guillet B. (1990) Cerium anomalies in lateritic profiles. Geochim. Cosmochim. Acta 54, 597-605.

Braun J. J., Pagel M., Herbillon A. and Rosen C. (1993) Mobilization and redistribution of REEs and thorium in a syenitic lateritic profile: A mass balance study. Geochim. Cosmochim. Acta 57, 4419-4434. 
Burdige D. J. and Gardner K. G. (1998) Molecular weight distribution of dissolved organic carbon in marine sediment pore waters. Mar. Chem. 62, 45-64.

Burnett W. C., Bokuniewicz H., Huettel M., Moore W. S. and Taniguchi M. (2003) Groundwater and pore water inputs to the coastal zone. Biogeochemistry 66, 3 33.

Byrne R. H. and Kim K.-H. (1990) Rare earth element scavenging in seawater. Geochim. Cosmochim. Acta 54, 2645-2656.

Byrne R. H. and Kim K.-H. (1993) Rare earth precipitation and coprecipitation behavior: The limiting role of $\mathrm{PO}_{4}{ }^{3-}$ on dissolved rare earth concentrations in seawater. Geochim. Cosmochim. Acta 57, 519-526.

Byrne R. H., Lee J. H., and Bingler L. S. (1991) Rare earth element complexation by $\mathrm{PO}_{4}{ }^{3-}$ ions in aqueous solution. Geochim. Cosmochim. Acta 55, 2729-2735.

Byrne, R.H., Liu, X., 1998. A coupled riverine-marine fractionation model for dissolved rare earths and yttrium. Aquatic Geochem. 4, 103-121.

Cai W.-J., Wang Y., Krest J. and Moore W. S. (2003) The geochemistry of dissolved inorganic carbon in a surficial groundwater aquifer in North Inlet, South Carolina, and the carbon fluxes to the coastal ocean. Geochim. Cosmochim. Acta 67, 631637.

Censi P., Sprovieri M., Saiano F., Di Geronimo S. I., Larocca D., and Placenti F. (2007) The behaviour of REEs in Thailand's Mae Klong estuary: Suggestions from the Y/Ho ratios and lanthanide tetrad effects. Estuar. Coast. Shelf Sci. 71, 569-579.

Charette M. A. and Buesseler K. O. (2004) Submarine groundwater discharge of nutrients and copper to an urban subestuary of Chesapeake Bay (Elizabeth River). Limnol. 
Oceanogr. 49, 376-385.

Charette M. A., Sholkovitz E. R. and Hansel C. M. (2005) Trace element cycling in a subterranean estuary: Part 1. Geochemistry of the permeable sediments. Geochim. Cosmochim. Acta 69, 2095-2109.

Chevis D. A., Johannesson K. H., Burdige D. J., Tang J., Moran S. B., and Kelly R. P. (2015a) Submarine groundwater discharge of rare earth elements to a tidallymixed estuary in Southern Rhode Island. Chem. Geol. 397, 128-142.

Chevis D. A., Johannesson K. H., Burdige D. J., Cable J. E., Martin J. B., and Roy M. (2015b) Rare earth element cycling in a sandy subterranean estuary in Florida, USA. Mar. Chem. 176, 34-50.

Chorover J., Amistadi M. K., and Chadwick O. A. (2004). Surface charge evolution of mineral-organic complexes during pedogenesis in Hawaiian basalt. Geochim. Cosmochim. Acta 23, 4859-4876.

Church T. M. (1996) An underground route for the water cycle. Nature 380, 579-580.

Clague D. A. and Bohrson W. A. (1991) Origin of xenoliths in the trachyte of Puu Waawaa, Hualalai Volcano, Hawaii. Contrib. Mineral. Petrol. 108, 439-452.

Clague D. A. and Dalrymple G. B. (1987) The Hawaiian-Emperor volcanic chain. Part 1: Geologic evolution. In: R. W. Decker, T. L. Wright, and P. H. Stauffer (Eds), Volcanism in Hawaii, U. S. Geol. Surv. Prof. Pap. 1350, 5-55.

Clague D. A., Jackon E. D., and Wright T. L. (1980) Petrology of Hualalai Volcano, Hawaii: Implications for mantle composition. Bull. Volcanol. 43-3, 641-656.

Clegg S. L. and Sarmiento J. L. (1989) The hydrolytic scavenging of metal ions by marine particulate matter. Prog. Oceanog. 23, 1-21. 
Cleveland W. S., Grosse E., and Shyu W. M. (1992) Chapter 8. Local regression models. In: J. M. Chambers, T. J. Hastie (eds.) Statistical Models in S, Chapman \& Hall/CRC Press, Boca Raton, FL, pp. 309-374.

Comans R. N. J. and van Dijk C. P. J. (1988) Role of complexation processes in cadmium mobilization during estuarine mixing. Nature 336, 151-154.

Cotton J., Le Dez A., Bau M., Caroff M., Maury R. C., Dulski P., Fourcade S., Bohn M., and Brousse R. (1995) Origin of anomalous rare-earth element and yttrium enrichments in subaerially exposed basalts: Evidence from French Polynesia. Chem. Geol. 119, 115-138.

Daux V., Crovisier J. L., Hemond C., and Petit J. C. (1994) Geochemical evolution of basaltic rocks subjected to weathering: Fate of the major elements, rare earth elements, and thorium. Geochim. Cosmochim. Acta 58, 4941-4954.

Delaney J. M. and Lundeen S. R. (1989) The LNLL thermochemical database. Lawrence Livermore National Laboratory, Report UCRL-21658.

Duarte T. K., Hemond H. F., Frankel D., and Frankel S. (2006) Assessment of submarine groundwater discharge by handheld aerial infrared imagery: Case study of Kaloko fishpond and bay, Hawai'i. Limnol. Oceanogr. Methods 4, 227-236.

Duddy I. R. (1980) Redistribution and fractionation of the rare-earth and other elements in weathering profiles. Chem. Geol. 30, 363-381.

Duncan T. and Shaw T. J. (2003) The mobility of the rare earth elements and redox sensitive elements in the groundwater/seawater mixing zone of a shallow coastal aquifer. Aquatic Geochem. 9, 233-255.

Dupré B., Gaillardet J., and Allègre C. J. (1996) Major and trace elements of river-borne 
material: the Congo Basin. Geochim. Cosmochim. Acta 60, 1301-1321.

Dzombak D. A. and Morel F. M. M. (1990) Surface Complexation Modeling. John Wiley and Sons, New York.

Efron B. and Tibshirani R. (1986) Bootstrap methods for standard errors, confidence intervals, and other measures of statistical accuracy. Stat. Sci. 1, 54-77.

Ekern P. C. and Chang J.-H. (1985) Pan evaporation: State of Hawai'i, 1894-1983. State of Hawaii, Department of Land and Natural Resources, Report 74R, 172 p.

Eggleton R. A., Foudoulis C., and Varkevisser D. (1987) Weathering of basalt: Changes in rock chemistry and mineralogy. Clays Clay Minerals 35, 161-169

Elderfield H., Greaves M. J. (1982) The rare earth elements in seawater. Nature 296, 214219.

Elderfield H. and Sholkovitz E. R. (1987) Rare earth elements in the pore waters of reducing nearshore sediments. Earth Planet. Sci. Lett. 82, 280-288.

Elderfield H., Upstill-Goddard R., Sholkovitz E. R. (1990) The rare earth elements in rivers, estuaries, and coastal seas and their significance to the composition of ocean waters. Geochim. Cosmochim. Acta 54, 971-991.

Erel Y. and Morgan J. J. (1991) The effect of surface reactions on the relative abundances of trace metals in deep-ocean water. Geochim. Cosmochim. Acta 55, 1807-1813.

Erel Y. and Stolper E. M. (1993) Modeling of rare-earth element partitioning between particles and solution in aquatic environments. Geochim. Cosmochim. Acta 57, 513-518.

Ericksson E. (1957) The chemical composition of Hawaiian rainfall. Tellus 9, 509-520. 
Fitzsimmons J. N. and Boyle E. A. (2012) An intercalibration between the GEOTRACES GO-FLO and the MITESS/Vanes sampling systems for dissolved iron concentration analyses (and a closer look at adsorption effects). Limnol. Oceanogr. Methods 10, 437-450.

Fitzsimmons J. N. and Boyle E. A. (2014) Assessment and comparison of Anopore and cross flow filtration methods for the determination of dissolved iron size fractionation into soluble and colloidal phases in seawater. Limnol. Oceanogr. Methods 12, 246-263.

Fodor R. V., Frey F. A., Bauer G. R., and Clague D. A. (1992a) Ages, rare-earth element enrichment, and petrogenesis of theoleiitic and alkaline basalts from Kahoolawe Island, Hawaii. Contrib. Mineral. Petrol. 110, 442-462.

Fodor R. V., Dobosi G., and Bauer G. R. (1992b) Anomalously high rare-earth element abundances in Hawaiian lavas. Anal. Chem. 64, 639-643.

Fodor R. V., Jacobs R. S., and Bauer G. R. (1994) Hollandite in Hawaiian basalt: a relocation site for weathering-mobilized elements. Mineral. Mag. 58, 589-596.

Fox L. E. (1990) Geochemistry of dissolved phosphate in the Sepik River and estuary, Papua, New Guinea. Geochim. Cosmochim. Acta 54, 1019-1024.

Fröllje H., Pahnke K., Schnetger B., Brumsack H.-J., Dulai H., and Fitzsimmons J. N. (2016) Hawaiian imprint on dissolved $\mathrm{Nd}$ and $\mathrm{Ra}$ isotopes and rare earth elements in the central North Pacific: Local survey and seasonal variability. Geochim. Cosmochim. Acta 189, 110-131.

Gaillardet J., Vier J., and Dupré B. (2005) Trace elements in river waters. In: J. I. Drever (ed.) Surface and Ground Water, Weathering, and Soils. Treatises on 
Geochemistry, Vol. 5. Elservier, Amsterdam, pp. 225-272.

Gallagher B. (1980) Physical structure and circulation in Honokohau, a small Hawaiian harbor affected by groundwater. Pac. Sci. 34, 301-311.

Garnier J.-M. and Guieu C. (2003) Release of cadmium in the Danube estuary: contribution of physical and chemical processes as determined by an experimental approach. Mar. Environ. Res. 55, 5-15.

Gillis K. M., Ludden J. N., and Smith A. D. (1992) Mobilization of REE during crustal aging in the Troodos Ophiolite, Cyprus. Chem. Geol. 98, 71-86.

Goldstein S. L. and Hemming S. R. (2003) Long-lived isotopic tracers in oceanography, paleoceanography, and ice-sheet dynamics. Treatise on Geochem. 6, 453-489.

Goldstein S. J. and Jacobsen S. B. (1988a) REE in the Great Whale River estuary, northwest Quebec. Earth Planet. Sci. Lett. 88, 241-252.

Goldstein S. J. and Jacobsen S. B. (1988b) Rare earth elements in river waters. Earth Planet. Sci. Lett. 89, 35-47.

Greaves M. J., Elderfield H., and Klinkhammer G. P. (1989) Determination of the rare earth elements in natural waters by isotope-dilution mass spectrometry. Anal. Chim. Acta 218, 265-280.

Haley B. A., Klinkhammer G. P., and McManus J. (2004) Rare earth elements in pore waters of marine sediments. Geochim. Cosmochim. Acta 68, 1265-1279.

Hanano D., Weis D., Scoates J. S., Aciego S., and DePaolo D. J. (2010) Horizontal and vertical zoning heterogeneities in the Hawaiian mantle plume from the geochemistry of consecutive postshield volcano pairs: Kohala - Mahukona and Mauna Kea - Hualalai. Geochem. Geophys. Geosyst. 11(1), Q01004, doi: 
10.1029/2009GC002782.

Hanor J. S. and Chan L.-H. (1977) Non-conservative behavior of barium during mixing of Mississippi River and Gulf of Mexico waters. Earth Planet. Sci. Lett. 37, 242250.

Hanson G. N. (1980) Rare earth elements in petrogenetic studies of igneous systems. Ann. Rev. Earth Planet. Sci. 8, 371-406.

Hatje V., Bruland K. W., and Flegal A. R. (2016) Increases in anthropogenic gadolinium anomalies and rare earth element concentrations in San Francisco Bay over a 20 year record. Environ. Sci. Technol. Doi:10.1021/acs.est5b04322.

Head P. C. (1985) Data presentation and interpretation. In P. C. Head (ed.) Practical Estuarine Chemistry: A Handbook. Cambridge University Press, Cambridge, UK, pp. 278-330.

Helgeson H. C. (1969) Thermodynamics of hydrothermal systems at elevated temperatures and pressures. Am. J. Sci. 267, 729-804.

Hoyle J., Elderfield H., Gledhill A., and Greaves M. (1984) The behaviour of the rare earth elements during the mixing of river and sea waters. Geochim. Cosmochim. Acta 48, 143-149.

Humphris S. E. (1984) The mobility of the rare earth elements in the crust. In: P. Henderson (Ed.) Rare Earth Element Geochemistry. Elsevier, Amsterdam, pp. $317-342$.

Hunt C. D., Jr. (2014) Baseline water-quality sampling to infer nutrient and contaminant sources at Kaloko-Honokohau National Historic Park, Island of Hawaii, 2009. U.S. Geol. Surv. Scientific Invest. Rept. 2014-5158, 52 p. 
Jakeš P., Gill J. (1970) Rare earth elements and the island arc tholeiitic series. Earth Planet. Sci. Lett. 9, 17-28.

Jeandel C., Bishop J. K. and Zindler A. (1995) Exchange of neodymium and its isotopes between seawater and small and large particles in the Sargasso Sea. Geochim. Cosmochim. Acta 59, 535-547.

Jeandel C., Thouron D. and Fiuex M. (1998) Concentrations and isotopic compositions of neodymium in the eastern Indian Ocean and Indonesian straits. Geochim. Cosmochim. Acta 62, 2597-2607.

Jeandel C., Delattre H., Grenier M., Pradoux C., and Lacan F. (2013) Rare earth element concentrations and $\mathrm{Nd}$ isotopes in the Southeast Pacific Ocean. Geochem. Geophys. Geosyst. 14, 328-341, doi:10.1029/2012GC003409.

Johannesson K. H., Burdige D. J. (2007) Balancing the global oceanic neodymium budget: evaluating the role of groundwater. Earth Planet. Sci. Lett. 253, 129-142.

Johannesson K. H., Lyons W. B., Stetzenbach K. J., and Byrne R. H. (1995) The solubility control of rare earth elements in natural terrestrial waters and the significance of $\mathrm{PO}_{4}{ }^{3-}$ and $\mathrm{CO}_{3}{ }^{2-}$ in limiting dissolved rare earth concentrations: $\mathrm{A}$ review of recent information. Aquatic Geochem. 1, 157-173.

Johannesson K. H., Farnham I. M., Gou C., and Stetzenbach K. J. (1999) Rare earth element fractionation and concentration variations along a groundwater flow path within a shallow, basin-fill aquifer, southern Nevada, USA. Geochim. Cosmochim. Acta 63, 2697-2708. 
Johannesson, K.H., Tang, J., Daniels, J.M., Bounds, W.J., and Burdige, D.J. (2004) Rare earth element concentrations and speciation in organic-rich blackwaters of the Great Dismal Swamp, Virginia, USA. Chem. Geol. 209, 271-294.

Johannesson K. H., Cortés A., Ramos Leal J. A., Ramírez A. G., Durazo J. (2005) Geochemistry of rare earth elements in groundwaters from a rhyolite aquifer, central México. In: Johannesson K. H. (ed) Rare earth elements in groundwater flow systems. Springer, Dordrecht, pp. 187-222.

Johannesson K.H., Chevis D. A., Burdige D. J., Cable J. E., Martin J. B., Roy M. (2011) Submarine groundwater discharge is an important net source of light and middle REEs to coastal waters of the Indian River Lagoon, Florida, USA. Geochim. Cosmochim. Acta 75, 825-843.

Johannesson K. H., Telfeyan K., Chevis D. A., Rosenheim B. E., Leybourne M. I. (2014) Rare earth elements in stromatolites -1 . Evidence that modern terrestrial stromatolites fractionate rare earth elements during incorporation from ambient waters. In: Y. Dilek, H. Furnes (eds.), Evolution of Archean Crust and Early Life, Modern Approaches in Solid Earth 1 Sciences 7, Springer, Dordrecht, 385-411.

Johnson A. G., Glenn C. R., Burnett W. C., Peterson R. N., and Lucey P. G. (2008) Aerial infrared imaging reveals large nutrient-rich groundwater inputs to the ocean. Geophys. Res. Lett. 35, L15606, doi:10.1029/2008/GL034574.

Jonasson R. G., Bancroft G. M., and Nesbitt H. W. (1985) Solubilites of some hydrous REE phosphates with implications for diagenesis and seawater concentrations. Geochim. Cosmochim. Acta 49, 2133-2139.

Kelly J. L. and Glenn C. R. (2015) Chlorofluorocarbon apparent ages of groundwaters 
from west Hawaii, USA. J. Hydrol. 527, 355-366.

Kim K.-H., Byrne R. H., and Lee J. H. (1991) Gadolinium behavior in seawater: a molecular basis for gadolinium anomalies. Mar. Chem. 36, 107-120.

Kim I. and Kim G. (2011) Large fluxes of rare earth elements through submarine groundwater discharge from a volcanic island, Jeju, Korea. Mar. Chem. 127, 1219.

Kim I. and Kim G. (2014) Submarine groundwater discharge as a main source of rare earth elements in coastal water. Mar. Chem. 160, 11-17.

Kim G., Ryu J.-W., Yang H.-S. and Yun S.-T. (2005) Submarine groundwater discharge (SGD) into the Yellow Sea revealed by ${ }^{228} \mathrm{Ra}$ and ${ }^{226} \mathrm{Ra}$ isotopes: implications for global silicate fluxes. Earth Planet. Sci. Lett. 237, 156-166.

Klinkhammer G., German C. R., Elderfield H., Greaves M. J., and Mitra A. (1994) Rare earth elements in hydrothermal fluids and plume particulates by inductively coupled plasma mass spectrometry. Mar. Chem. 45, 170-186.

Klungness G. D. and Byrne R. H. (2000) Comparative hydrolysis behavior of the rare earths and yttrium: the influence of temperature and ionic strength. Polyhedron 19, 99-107.

Knee K. L., Street J. H., Grossman E. E., Boehm A. B., and Paytan A. (2010) Nutrient inputs to the coastal ocean from submarine groundwater discharge in a groundwater-dominated system: Relation to land use (Kona Coast, Hawaii, U. S. A.). Limnol. Oceanogr. 53, 1105-1122.

Koeppenkastrop D. and De Carlo E. H. (1992) Sorption of rare-earth elements from seawater onto synthetic mineral particles: An experimental approach. Chem. Geol. 
95, 251-263.

Koeppenkastrop D. and De Carlo E. H. (1993) Uptake of rare earth elements from solution by metal oxides. Environ. Sci. Technol. 27, 1796-1802.

Kraepiel A. M. L., Chiffoleau J.-F., Martin J.-M., and Morel F. M. M. (1997) Geochemistry of trace metals in the Gironde estuary. Geochim. Cosmochim. Acta 61, 1421-1436.

Kulaksız S. and Bau M. (2007) Contrasting behaviour of anthropogenic gadolinium and natural rare earth elements in estuaries and the gadolinium input to the North Sea. Earth Planet. Sci. Lett. 260, 361-371.

Kümmerer K. and Helmers E. (2000) Hospital effluents as a source of gadolinium in the aquatic environment. Environ. Sci. Technol. 34, 573-577.

Lacan F. and Jeandel C. (2001) Tracing Papua New Guinea imprint on the Equatorial Pacific Ocean using neodymium isotopic compositions and rare earth element patterns. Earth Planet. Sci. Lett. 186, 497-512.

Lacan F. and Jeandel C. (2005) Neodymium isotopes as a new tool for quantifying exchange fluxes at the continent-ocean interface. Earth Planet. Sci. Lett. 232, 245-257.

Lau L. S. and Mink J. F. (2006) Hydrology of the Hawaiian Islands. University of Hawai'i Press, Honolulu.

Lawrence M. G. and Kamber B. S. (2006) The behaviour of the rare earth elements during estuarine mixing - revisted. Mar. Chem. 100, 147-161.

Lee J. H. and Byrne R. H. (1992) Examination of comparative rare earth element complexation behavior using linear free-energy relationships. Geochim. 
Cosmochim. Acta 56, 1127-1137.

Li Y.-H and Chan L.-H. (1979) Desorption of Ba and ${ }^{226} \mathrm{Ra}$ from river-borne sediments in the Hudson estuary. Earth Planet. Sci. Lett. 43, 343-350.

Liu X. and Byrne R. H. (1997) Rare earth and yttrium phosphate solubilities in aqueous solution. Geochim. Cosmochim. Acta 61, 1625-1633.

Luo Y.-R. and Byrne R. H. (2000) The ionic strength dependence of rare earth and yttrium fluoride complexes at $25^{\circ}$ C. J. Sol. Chem. 30, 837-845.

Luo Y.-R. and Byrne R. H. (2001) Yttrium and rare earth element complexation by chloride ions at $25^{\circ}$ C. J. Sol. Chem. 30, 837-845.

Luo Y.-R. and Byrne R. H. (2004) Carbonate complexation of yttrium and the rare earth elements in natural waters. Geochim. Cosmochim. Acta 68, 691-699.

Maeda M. and Windom H. L. (1982) Behavior of uranium in two estuaries of the southeastern United States. Mar. Chem. 11, 427-436.

Martin J. B., Cable J. E., Smith C., Roy M. and Cherrier J. (2007) Magnitudes of submarine groundwater discharge from marine and terrestrial sources: Indian River Lagoon, Florida. Water Resour. Res., 43, W05440. doi:10.1029/2006WR005266.

Martin J.-M., Høgdahl O., and Philippot J. C. (1976) Rare earth supply to the ocean. J. Geophys. Res. 81, 3119-3124.

McKenzie D., O’Nions R. K. (1991) Partial melt distributions from inversion of rare earth element concentrations. J. Petrol. 32, 1021-1091.

Millero F. J. and Schreiber D. R. (1982) Use of the ion pairing model to estimate activity coefficients of the ionic components of natural waters. Am. J. Sci. 282, 1508- 
1540.

Milliman J. D. and Farnsworth K. L. (2011) River Discharge to the Coastal Ocean: A Global Synthesis. Cambridge University Press, Cambridge, UK, 384 p.

Mohajerin T. J., Helz G. R., and Johannesson K. H (2016) Tungsten - molybdenum fractionation in estuarine environments. Geochim. Cosmochim. Acta 177, 105119.

Moore J. G. and Clague D. (1987) Coastal lava flows from Mauna Loa and Hualalai volcanoes, Kona, Hawaii. Bull. Volcanol. 49, 752-764.

Moore J. G. and Clague D. A. (1992) Volcano growth and evolution of the island of Hawaii. Geol Soc. Am. Bull. 104, 1471-1484.

Moore J. G., Clague D. A., Rubin M., and Bohrson W. A. (1987) Hualalai Volcano: A preliminary summary of geologic, petrologic, and geophysical data. In: R. W. Decker, T. L. Wright, and P. H. Stauffer (Eds), Volcanism in Hawaii, U. S. Geol. Surv. Prof. Pap 1350, 571-585.

Moore W. S. (1997) High fluxes of radium and barium from the mouth of the GangesBrahmaputra River during low river discharge suggest a large groundwater source. Earth Planet. Sci. Lett. 150, 141-150.

Moore W. S. (1999) The subterranean estuary: A reaction zone of groundwater and seawater. Mar. Chem. 65, 111-125.

Moore W. S. (2010) The effect of submarine groundwater discharge on the ocean. Аnпи. Rev. Mar. Sci. 2, 59-88.

Nance W. B. and Taylor S. R. (1976) Rare earth element patterns and crustal evolution I. Australian post-Archean rocks. Geochim. Cosmochim. Acta 40, 1539-1551. 
Nelson B. J., Wood S. A., and Osiensky J. L. (2004) Rare earth element geochemistry in the Palouse Basin, northern Idaho - eastern Washington. Geochem. Explor. Environ. Anal. 4, 227-241.

Nesbitt H. W. (1979) Mobility and fractionation of the rare earth elements during weathering of a granodiorite. Nature $\mathbf{2 7 9}, 206-210$.

Nesbitt H. W. and Wilson R. E. (1992) Recent chemical weathering of basalts. Am. J. Sci. 292, 740-777.

Nozaki Y., Yamamoto Y., Manaka T., Amakawa H., and Snidvongs A. (2001) Dissolved barium and radium isotopes in the Chao Phraya River estuarine mixing zone in Thailand. Continent. Shelf Res. 21, 1435-1448.

Officer C. B. (1979) Discussion of the behaviour of nonconservative dissolved constituents in estuaries. Estuar. Coast. Mar. Sci. 9, 91-94.

Oki D. S., Tribble G. W., Souza W. R., and Bolke E. L. (1999) Groundwater resources in Kaloko-Honokohua National Historic Park, Island of Hawaii, and numerical simulation of the effects of groundwater withdrawals. U. S. Geol. Surv. Water Resour. Invest. Rep., 99-4070, 49 pp.

Parsons M. L., Walsh W. J., Settlemeir C. J., White D. J., Ballauer J. M., Ayotte P. M., Osada K. M., and Carman B. (2008) A multivariate assessment of the coral ecosystem health of two embayments on the less of the island of Hawai'i. Mar. Pollut. Bull. 56, 1138-1149.

Peterson R. N., Burnett W. C., Glenn C. R., and Johnson A. G. (2007) A box model to quantify groundwater discharge along the Kona coast of Hawaii using natural tracers. In: W. Sanford et al. (Eds) A New Foocus on Groundwater-Seawater 
Interactions, IAHS Publ. 312, 142-149.

Peterson R. N., Burnett W. C., Glenn C. R., and Johnson A. G. (2009) Quantification of point-source groundwater discharges to the ocean from the shoreline of the Big Island, Hawaii. Limnol. Oceanogr. 54, 890-904.

Piepgras D. J. and Jacobsen S. B. (1992) The behavior of rare earth elements in seawater: Precise determination of variations in the North Pacific water column. Geochim. Cosmochim. Acta 56, 1851-1862.

Piepgras D. J. and Wasserburg G. J. (1987) Rare earth element transport in the western North Atlantic inferred from Nd isotopic observations. Geochim. Cosmochim. Acta 51,1257-1271.

Price R. C., Gray C. M., Wilson R. E., Frey F. A., and Taylor S. R. (1991) The effects of weathering on rare-earth element, $\mathrm{Y}$ and $\mathrm{Ba}$ abundances in Tertiary basalts from southeastern Australia. Chem. Geol. 93, 245-265.

Prouty N. G., Swarzenski P. W., Fackrell J. K., Johannesson K., and Palmore D. (2016) Groundwater-derived nutrients and trace element transport to a nearshore Kona coral ecosystem: Experimental mixing model results. J. Hydrol.: Reg. Stud., http://dx.doi.org/10.1016/j.ejrh.2015.12.058.

Quinn K. A., Byrne R. H. and Schijf J. (2004) Comparative scavenging of yttrium and the rare earth elements in seawater: Competitive influences of solution and surface chemistry. Aquatic Geochem. 10, 59-80.

Quinn K. A., Byrne R. H. and Schijf J. (2006) Sorption of yttrium and rare earth elements by amorphous ferric hydroxide: Influence of solution complexation with carbonate. Geochim. Cosmochim. Acta 70, 4151-4165. 
R Core Team (2015) R: A Language and Environment for Statistical Computing. R Foundation for Statistical Computing, Vienna, Austria.

Ren Z.-Y., Hanyu T., Miyazaki T., Chang Q., Kawabata H., Takahashi T., Hirahara Y. Nichols A. R. L., and Tatsumi Y. (2009) Geochemical differences of the Hawaiian shield labes: Implications for melting process in the heterogeneous Hawaiian plume. J. Petrol. 50, 1553-1573.

Ronov A. B., Balashov Y. A., and Migdisov A. A. (1967) Geochemistry of the rare earth elements in the sedimentary cycle. Geochem. Internat. 4, 1-17.

Rousseau T. C. C., Sonke J. E., Chmeleff J., van Beek P., Souhaut M., Boaventura G., Seyler P., and Jeandel C. (2015) Rapid neodymium rlease to marine waters from lithogenic sediments in the Amazon estuary. Nature Commun. 6:7592 doi:10.1038/ncomms8592.

Roy M., Martin J. B., Cherrier J., Cable J. E. and Smith C. G. (2010) Influence of sea level rise on iron diagenesis in an east Florida subterranean estuary. Geochim. Cosmochim. Acta 74, 5560-5573.

Roy M., Martin J. B., Smith C. G., and Cable J. E. (2011) Reactive-transport modeling of iron diagenesis and associated organic carbon mineralization in a Florida (USA) subterranean estuary. Earth Planet. Sci. Lett. 304, 191-201.

Schijf J. and Byrne R. H. (2004) Determination of ${ }_{\mathrm{sO}_{4}} \beta_{1}$ for yttrium and the rare earth elements at $I=0.66 \mathrm{~m}$ and $t=25^{\circ} \mathrm{C}-$ Implications for YREE solution speciation in sulfate-rich waters. Geochim. Cosmochim. Acta 68, 2825-2837.

Schneider A. B., Kochinsky A., Kiprotich J., Poehle S., and do Nascimento P. C. (2016) An experimental study on the mixing behavior of $\mathrm{Ti}, \mathrm{Zr}, \mathrm{V}$ and $\mathrm{Mo}$ in the Elbe, 
Rhine and Weser estuaries. Estuar. Coast. Shelf Sci. 170, 34-44.

Shannon W. M. and Wood S. A. (2005) The analysis of pictogram quantities of rare earth elements in natural waters. In: K. H. Johannesson (ed.) Rare Earth Elements in Groundwater Flow Systems. Springer, Dordrecht, 1-37.

Shiller A. M. (2003) Syringe filtration method for examining dissolved and colloidal trace element distributions in remote field locations. Environ. Sci. Technol. 37, 3953-3957.

Sholkovitz E. R. (1976) Flocculation of dissolved organic and inorganic matter during the mixing of river water and seawater. Geochim. Cosmochim. Acta 40, 831-845.

Sholkovitz E. R. (1992) Chemical evolution of rare earth elements: fractionation between colloidal and solution phases of filtered river water. Earth Planet Sci. Lett. 114, $77-84$.

Sholkovitz E. R. (1993) The geochemistry of rare earth elements in the Amazon River estuary. Geochim. Cosmochim. Acta 57, 2181-2190.

Sholkovitz E. R. (1995) The aquatic chemistry of rare earth elements in rivers and estuaries. Aquatic Geochem. 1, 1-34.

Sholkovitz E. R. and Copland D. (1981) The coagulation, solubility and adsorption properties of $\mathrm{Fe}, \mathrm{Mn}, \mathrm{Cu}, \mathrm{Ni}, \mathrm{Cd}$, $\mathrm{Co}$ and humic acids in river water. Geochim. Cosmochim. Acta 45, 181-198.

Sholkovitz E. R. and Elderfield H. (1988) Cycling of dissolved rare earth elements in Chesapeake Bay. Global Biogeochem. Cycles 2, 157-176.

Sholkovitz E. R. and Szymczak R. (2000) The estuarine chemistry of rare earth elements: comparison of the Amazon, Fly, Sepik and the Gulf of Papua systems. Earth 
Planet. Sci. Lett. 179, 299-309.

Sholkovitz E. R., Piepgras D. J., and Jacobsen S. B. (1989) The pore water chemistry of rare earth elements in Buzzards Bay sediments. Geochim. Cosmochim. Acta 53, 2847-2856.

Sholkovitz E. R., Shaw T. J., and Schneider D. L. (1992) The geochemistry of rare earth elements in the seasonally anoxic water column and porewaters of Chesapeake Bay. Geochim. Cosmochim. Acta 56, 3389-3402.

Siddall M., Khatiwala S., van de Flierdt T., Jones K., Goldstein S. L., Hemming S. and Anderson R. F. (2008) Towards explaining the $\mathrm{Nd}$ paradox using reversible scavenging in an ocean general circulation model. Earth Planet. Sci. Lett. 274, 448-461.

Slomp C. P. and Van Cappellen P. (2004) Nutrient inputs to the coastal ocean through submarine groundwater discharge: controls and potential impact. J. Hydrol. 295, 64-86.

Stefánsson A. and Gíslason S. R. (2001) Chemical weathering of basalts, Southwestern Iceland: Effect of rock crystallinity and secondary minerals on chemical fluxes to the ocean. Am. J. Sci. 301, 513-556.

Street J. H., Knee K. L., Grossman E. E., Paytan A. (2008) Submarine groundwater discharge and nutrient addition to the coastal zone and coral reefs of leeward Hawai’i. Mar. Chem. 109, 355-376.

Swarzenski P. W., McKee B. A., and Booth J. G. (1995) Uranium geochemistry on the Amazon shelf: Chemical phase partitioning and cycling across as a salinity gradient. Geochim. Cosmochim. Acta 59, 7-18. 
Tachikawa K., Jeandel C. and Dupre' B. (1997) Distribution of rare earth elements and neodymium isotopes in settling particulate material of the tropical Atlantic Ocean (EUMELI site). Deep-Sea Res. I 44, 1769-1792.

Tachikawa K., Jeandel C. and Roy-Barman M. (1999a) A new approach to Nd residence time: The role of atmospheric inputs. Earth Planet. Sci. Lett. 170, 433-446.

Tachikawa K., Jeandel C., Vangriesheim A. and Dupre' B. (1999b) Distribution of rare earth elements and neodymium isotopes in suspended particles of the tropical Atlantic Ocean (EUMELI site). Deep-Sea Res. I 46, 733-756.

Tachikawa K., Athias V. and Jeandel C. (2003) Neodymium budget in the modern ocean and paleo-oceanographic implications. J. Geophys. Res. 108, 3254. doi:10.1029/1999JC000285.

Tanaka R., Makishima A., and Nakamura E. (2008) Hawaiian double volcanic chain triggered by an episodic involvement of recycled material: Constraints from temporal $\mathrm{Sr}-\mathrm{Nd}-\mathrm{Hf}-\mathrm{Pb}$ isotopic trend of the Loa-type volcanoes. Earth Planet. Sci. Lett. 265, 450-465.

Tang J. and Johannesson K. H. (2005) Adsorption of rare earth elements onto Carrizo sand: Experimental investigations and modeling with surface complexation. Geochim. Cosmochim. Acta 69, 5247-5261.

Tang J. and Johannesson K. H. (2010a) Ligand extraction of rare earth elements from aquifer sediments: Implications for rare earth element complexation with organic matter in natural waters. Geochim. Cosmochim. Acta 74, 6690-6705.

Tang J. and Johannesson K. H. (2010b) Rare earth adsorption onto Carrizo sand: Influences of strong solution complexation. Chem. Geol. 279, 120-133. 
Taniguchi M., Burnett W. C., Cable J. E. and Turner J. V. (2002) Investigation of submarine groundwater discharge. Hydrol. Process. 16, 2115-2129.

Tatsumi T., Shukuno H., Yoshikawa M., Chang Q., Sato K., and Lee M. W. (2004) The petrology and geochemistry of volcanic rocks on Jeju Island: Plume magmatism along the Asian continental margin. J. Petrol. 46, 523-553.

Taylor S. R. and McLennan S. M. (1985) The Continental Crust: Its Composition and Evolution. Blackwell Scientific Publications, Oxford, UK.

Tillman F. D., Oki D. S., Johnson A. G., Barber L. B., and Beisner K. R. (2014a) Investigation of geochemical indicators to evaluate the connection between inland and coastal groundwater systems near Kaloko-Honokōhau National Historical Park, Hawai'i. Applied Geochem. 51, 278-292.

Tillman F. D., Oki D. S., and Johnson A. G. (2014b) Water-chemistry data collected in and near Kaloko-Honokōhau National Historical Park, Hawai'I, 2012-2014. U. S. Geol. Surv. Open-File Rept. 2014-1173.

Verplanck P. L., Taylor H. E., Nordstrom D. K., and Barber L. B. (2005) Aqueous stability of gadolinium in surface waters receiving sewage treatment plant effluent, Boulder Creek, Colorado. Environ. Sci. Technol. 39, 6923-6929.

Visher F. N. and Mink J. F. (1964) Ground-water resources in southern Oahu, Hawaii. $U$. S. Geol. Surv. Water Supply Pap. 1778, 133 p.

Willis S. S., Johannesson K. H. (2011) Controls on the geochemistry of rare earth elements in sediments and groundwaters of the Aquia aquifer, Maryland, USA. Chem. Geol. 285, 32-49.

Windom H. L., Moore W. S., Niencheski L. F. H. and Jahnke R. A. (2006) Submarine 
groundwater discharge: A large, previously unrecognized source of dissolved iron to the South Atlantic Ocean. Mar. Chem. 102, 252-266.

Ziegler K., Hsieh J. C. C., Chadwick O. A., Kelly E. F., Hendricks D. M., and Savin S. M. (2003) Halloysite as a kinetically controlled end product of arid-zone basalt weathering. Chem. Geol. 202, 461-478.

Zucca J. J., Hill D. P., and Kovach R. L. (1982) Crustal structure of Mauna Loa Volcano, Hawaii, from seismic refraction and gravity data. Bull. Seismol. Soc. Am. 72, $1535-1550$.

\section{Figure Captions}

Figure 1. Map of the study site on the Big Island of Hawaii is shown in panel (a). Panel (b) depicts the general setting of the portion of the Kona Coast investigated and includes the location of the Hind well on Kiholo Bay and the groundwater wells in the KalokoHonokohau National Historic Park. Panel (c) is a detailed map of the vicinity of the Kaloko-Honokohau National Historic Park showing the locations of the Honokohau Harbor well, the three KAHO wells within the Park, and the location of where the coastal seawater sample was collected.

Figure 2. Piper diagram for Kona Coast groundwaters and coastal seawater. Groundwaters are largely $\mathrm{Na}-\mathrm{HCO}_{3}$ to $\mathrm{Na}-\mathrm{Cl}$ waters. 
Figure 3. Shale-normalized REE patterns for groundwaters and the coastal seawater sample collectd from the Kona Coast. Shown are the results for waters filtered through $0.45 \mu \mathrm{m}$ (filled symbols) and through $0.02 \mu \mathrm{m}$ (open symbols) filters, except for panel (b), which shows duplicate samples from the KAHO 1 well. For each case, the symbol and error bars represent the mean and relative standard deviation (RSD) for five replicate analyses, and hence, show the instrument precision. The KAHO 1 analyses represent the sampling and laboratory precision. Rare earth element concentrations measured in each water sample are normalized to the Post Archean Australian Shale (PAAS) composite (Nance and Taylor, 1976).

Figure 4. Shale-normalized REE patterns for Kono Coast groundwaters and coastal seawaters compared to open-ocean North Pacific seawater. Panel (a) demonstrates the nearly identical shale-normalized REE patterns of Kona groundwaters and seawater samples. The chief exception is that the majority of groundwaters do not exhibit a large positive Gd anomaly that evident in groundwater from the Honokohau Harbor well as well as the coastal seawater sample. Panel (b) compares Kona Coast seawater with a number of open-ocean seawater samples from various depths taken from Alibo and Nozaki (1999). Although the North Pacific seawater samples were filtered through 0.04 $\mu \mathrm{m}$ pore-size filters, Kona Coast seawater filtered through $0.02 \mu \mathrm{m}$ has substantially higher REE concentrations. See text for details.

Figure 5. Kona Coast groundwaters and coastal seawater normalized to the mean REE content of twelve, alkali Hualali basalts from Hanano et al. (2010). Panels (a) and (b) 
present the basalt-normalized REE patterns of waters filtered through $0.45 \mu \mathrm{m}$ and 0.02 $\mu \mathrm{m}$ pore-size filters, respectively.

Figure 6. Results of the Honokohau Harbor mixing experiment for (a) Nd, (b) Gd, and (c) $\mathrm{Yb}$, plotted as a function of salinity. Each symbol shows the mean and the RSD for each analysis. The dashed line depicts the hypothetic conservative mixing/dilution line between Honokohau Harbor well groundwater and coastal seawater.

Figure 7. Results of the lava tube mixing experiment for (a) $\mathrm{Nd}$, (b) $\mathrm{Gd}$, and (c) $\mathrm{Yb}$, plotted as a function of salinity. Each symbol shows the mean and the RSD for each analysis. The dashed line depicts the hypothetic conservative mixing/dilution line between Hind well groundwater and coastal seawater.

Figure 8. Solution complexation model results for Kona Coast groundwaters and coastal seawater, where Ln represents each of the individual REEs (i.e., lanthanides). Major ion chemistry used for the modeling is presented in Table 2.

Figure 9. Results of solution complexation modeling for the Honokohau Harbor mixing experiment (see electronic annex). Panel (a) presents the activity of the free metal ions. $\left[\mathrm{Ln}^{3+}\right]_{\mathrm{F}}$, for $\mathrm{La}, \mathrm{Nd}, \mathrm{Gd}, \mathrm{Dy}$, and $\mathrm{Yb}$ as a function of salinity, whereas panels (b) and (c) present the predicted speciation of $\mathrm{Nd}$ (a LREE) and $\mathrm{Yb}$ (a HREE) as a function of salinity, respectively. Panels (b) and (c) only show aqueous species that are predicted to account for $1 \%$ and greater of any of the REEs. 
Figure 10. Results of solution complexation modeling for the lava tube mixing experiment (see electronic annex). Panel (a) presents the activity of the free metal ions. $\left[\mathrm{Ln}^{3+}\right]_{\mathrm{F}}$, for La, Nd, Gd, Dy, and $\mathrm{Yb}$ as a function of salinity, whereas panels (b) and (c) present the predicted speciation of $\mathrm{Nd}$ (a LREE) and $\mathrm{Yb}$ (a HREE) as a function of salinity, respectively. Panels (b) and (c) only show aqueous species that are predicted to account for at $0.1 \%$ and greater of any of the REEs.

Figure 11. Calculated Gd-normalized solution-surface partition coefficient $\left(D_{\mathrm{Ln}} / D_{\mathrm{Gd}}\right)^{-1}$ as a function of salinity for the Honokohau Harbor mixing experiment.

Figure 12. Kona Coast groundwaters normalized to the Kona seawater sample. The generally flat patterns with normalized ratios around unity emphasize the similarity of these groundwaters and the coast seawater.

Figure 13. Analysis of the (a) Honokohau Harbor and (b) lava tube mixing experiments for $\mathrm{Nd}$ as a function of salinity. Measured concentration data are show as open circles and the hypothetical conservative mixing/dilution line is represented by the dashed line (compare with Figs. 6a and 7a). Solid orange-brown curved line is the median loess fit to the measured $\mathrm{Nd}$ concentration data and the orange-brown field represents the $95 \%$ confidence interval for the loess fit. The solid blue straight line is the median tangent line constructed from the seawater endmember back to the freshwater endmember (salinity of zero) and the blue, triangle shaped field is the corresponding 95\% confidence interval. 
The resulting median $y$-intercept shown by the blue dot on the ordinate at zero salinity, which is mathematically equal to $\left.[\mathrm{Ln}]_{\mathrm{TSGD}}+\frac{J_{\mathrm{desorb}}^{[\mathrm{Ln}]}}{\mathrm{Q}_{\mathrm{TSGD}}}\right)$, and reflects the effective, freshwater (terrestrial) SGD concentration of Nd. See text for details. 
Table 1. Location and sampling data for groundwater wells and seawater samples collected along the Kona Coast.

\begin{tabular}{lccccccc}
\hline & $\begin{array}{c}\text { Latitude } \\
(\text { North) }\end{array}$ & $\begin{array}{c}\text { Longitude } \\
\text { (West) }\end{array}$ & $\begin{array}{c}\text { Elevation } \\
(\mathrm{m})\end{array}$ & $\begin{array}{c}\text { Hole Depth } \\
(\mathrm{m})\end{array}$ & $\begin{array}{c}\text { Well Depth } \\
(\mathrm{m})\end{array}$ & $\begin{array}{c}\text { Depth to Water } \\
(\mathrm{m})\end{array}$ & Notes \\
\hline Seawater & $19^{\circ} 40^{\prime} 07.98^{\prime \prime}$ & $156^{\circ} 01^{\prime} 58.80^{\prime \prime}$ & 0 & - & 0 & Surface & $\sim 0.62 \mathrm{~km}$ offshore \\
Honokohau Harbor Well & $19^{\circ} 40^{\prime} 06.60^{\prime \prime}$ & $156^{\circ} 01^{\prime} 15.60^{\prime \prime}$ & - & - & - & 12.1 & Outside harbor road entrance \\
KAHO 1 Well & $19^{\circ} 40^{\prime} 42.06^{\prime \prime}$ & $156^{\circ} 01^{\prime} 19.99^{\prime \prime}$ & 11.1 & 15.8 & 13.1 & 6.96 & USGS, 8-4061-01 \\
KAHO 2 Well & $19^{\circ} 41^{\prime} 09.04^{\prime \prime}$ & $156^{\circ} 01^{\prime} 25.01^{\prime \prime}$ & 16.3 & 21 & 18.4 & 16.1 & USGS, 8-4161-02 \\
KAHO 3 Well & $19^{\circ} 41^{\prime} 14.06^{\prime \prime}$ & $156^{\circ} 01^{\prime} 44.99^{\prime \prime}$ & 7.02 & 10.4 & 9.48 & 11 & USGS, 8-4161-01 \\
Hind Well & $19^{\circ} 51^{\prime} 14.40^{\prime \prime}$ & $155^{\circ} 55^{\prime} 22.80^{\prime \prime}$ & - & - & - & $\sim 1.5$ & In collapsed lava tube \\
\hline
\end{tabular}


Table 2. Chemistry of coastal groundwaters and seawater from the Kona Coast of Hawaii. Major solutes, nutrients, and Fe and Mn concentrations are for the dissolved fraction (< $0.45 \mu \mathrm{m})$.

\begin{tabular}{|c|c|c|c|c|c|c|}
\hline & $\begin{array}{l}\text { Coastal } \\
\text { Seawater }\end{array}$ & $\begin{array}{l}\text { Honokohau } \\
\text { HarborWell }\end{array}$ & KAHO 1 & KAHO 2 & KAHO 3 & Hind Well \\
\hline $\mathrm{pH}$ & 8.03 & 6.9 & 7.15 & 7.55 & 6.76 & 7.7 \\
\hline Temp. ${ }^{\circ} \mathrm{C}$ & $\sim 27$ & 23.1 & 20.1 & 20.9 & 21.1 & 22.3 \\
\hline Cond. $^{\mathrm{a}}$ & 53.4 & 9.08 & 10.7 & 8.81 & 18.7 & 3.93 \\
\hline Salinity $^{\mathrm{b}}$ & 36.7 & 4.8 & 5.7 & 4.5 & 12.5 & 2 \\
\hline Ionic Strength ${ }^{c}$ & 0.745 & 0.187 & 0.223 & 0.263 & 0.649 & 0.178 \\
\hline $\mathrm{DO}^{\mathrm{d}}$ & - & 83.4 & 173 & 197 & 154 & 252 \\
\hline $\mathrm{DO}^{\mathrm{e}}$ & - & 31.9 & 63 & 72.7 & 58.9 & 93.8 \\
\hline $\operatorname{Eh}(\text { volts })^{\mathrm{f}}$ & 0.744 & 0.804 & 0.794 & 0.771 & 0.817 & 0.763 \\
\hline $\mathrm{SPM}^{\mathrm{f}}$ & 7.79 & 2.02 & 2.13 & 1.74 & 2.04 & 0.8 \\
\hline \multicolumn{7}{|l|}{ mmol kg-1 } \\
\hline $\mathrm{Ca}$ & 6.5 & 1.22 & 1.26 & 1.1 & 1.91 & 0.76 \\
\hline $\mathrm{Mg}$ & 54.5 & 8.21 & 11.2 & 8.17 & 15.4 & 4.34 \\
\hline $\mathrm{Na}$ & 633 & 153 & 179 & 230 & 548 & 88.8 \\
\hline $\mathrm{K}$ & 10.6 & 1.8 & 2.05 & 1.65 & 3.04 & 0.86 \\
\hline $\mathrm{Cl}$ & 572 & 74.8 & 89.6 & 70.2 & 195 & 31.6 \\
\hline $\mathrm{Alk}^{\mathrm{g}}$ & 123 & 89.9 & 106 & 172 & 370 & 138 \\
\hline $\mathrm{SO}_{4}$ & 34.6 & 4.26 & 4.96 & 3.86 & 10.2 & 1.88 \\
\hline $\mathrm{F}$ & 0.37 & 0.12 & 0.15 & 0.14 & 0.19 & 0.28 \\
\hline $\mathrm{Br}$ & 0.99 & 0.14 & 0.15 & 0.11 & 0.3 & 0.05 \\
\hline \multicolumn{7}{|l|}{$\mu \mathrm{mol} \mathrm{kg}{ }^{-1}$} \\
\hline $\mathrm{NO}_{3}+\mathrm{NO}_{2}$ & 4.2 & 187 & 66.5 & 31.2 & 39.3 & 26.5 \\
\hline $\mathrm{NH}_{4}$ & 0.1 & 1.3 & 0.9 & 1.1 & 2.2 & 0.3 \\
\hline $\mathrm{PO}_{4}$ & 0.15 & 37.3 & 3.6 & 2.1 & 2.7 & 1.9 \\
\hline $\mathrm{H}_{4} \mathrm{SiO}_{4}$ & 28.4 & 376 & 389 & 392 & 311 & 432 \\
\hline DOC & - & 236 & 45 & 51.6 & 35.8 & - \\
\hline \multicolumn{7}{|l|}{ nmol kg-1 } \\
\hline $\mathrm{Fe}$ & 11.6 & 11.3 & ND & 62.5 & 11.5 & ND \\
\hline Mn & 1.2 & 0.6 & 7.9 & 11.6 & 2.1 & 6.4 \\
\hline $\begin{array}{l}{ }^{\mathrm{a}} \mu \mathrm{S} \mathrm{cm}{ }^{-1} \\
\mathrm{bComputed} \mathrm{from}{ }^{\mathrm{c}} \text { moles kg }{ }^{-1} \\
{ }^{\mathrm{d}} \mu \mathrm{mol} \mathrm{kg} \mathrm{kg}^{-1} \\
{ }^{\mathrm{e}} \text { Percent saturatio } \\
{ }^{\mathrm{f}} \text { Suspended partic } \\
{ }^{\mathrm{g}} \text { Alkalinity estima } \\
{ }^{2011) .} \\
{ }^{\mathrm{f}} \text { Computed based } \\
\text { ND = not detectec }\end{array}$ & $\begin{array}{l}\text { l concentrat } \\
\text { ate matter (1 } \\
\text { d from char } \\
\text { n dissolve or }\end{array}$ & $\begin{array}{l}\text { using } \mathrm{S}\left(\mathrm{g} \mathrm{kg}^{-}\right. \\
\left.\mathrm{L}^{-1}\right) \\
\text { balance and is } \\
\text { gen concentrati }\end{array}$ & $=1.80655$ & $\mathrm{Cl}\left(\mathrm{g} \mathrm{kg}^{-1}\right)$ & s and Johanr & sson, \\
\hline
\end{tabular}


Table 3. Summary of published geochemical data for rivers and estuaries ${ }^{\mathrm{a}}$.

\begin{tabular}{lcccccc}
\hline River & $\mathrm{pH}$ & $\begin{array}{c}\mathrm{Fe} \\
\mathrm{nmol} \mathrm{kg}^{-1}\end{array}$ & $\begin{array}{c}\mathrm{Mn} \\
\mathrm{nmol} \mathrm{kg}^{-1}\end{array}$ & $\begin{array}{c}\mathrm{DOC} \\
\mu \mathrm{mol} \mathrm{kg}^{-1}\end{array}$ & $\begin{array}{c}\mathrm{Nd} \\
\mathrm{pmol} \mathrm{kg}^{-1}\end{array}$ & $\begin{array}{c}\mathrm{Nd} \mathrm{Removed}^{\mathrm{b}} \\
\%\end{array}$ \\
\hline Mississippi & & & & & & - \\
$\quad$ Upper & 7.7 & - & 7.46 & - & - & - \\
$\quad$ Mouth & 7.8 & - & $12-33$ & - & 76.3 & - \\
Connecticut & 7.0 & 108 & 42 & 267 & 2475 & 56 \\
St. Lawrence & 8.0 & 1990 & 114 & - & 263 & - \\
Mullica & 4.6 & 60 & 62 & - & 2856 & 81 \\
Delaware & 7.5 & 9 & 9.4 & 217 & 180 & 70 \\
Hudson & 7.0 & - & - & - & 416 & - \\
Great Whale & 6.9 & 580 & - & 441 & 1158 & 66 \\
& & & & & & \\
Amazon & & & & & & \\
$\quad$ Mean & 6.89 & - & 923 & 425 & $837 \pm 259$ & $93-95$ \\
$\quad$ C.2 $\mu$ m & 7.1 & 770 & 60 & 420 & - & - \\
Orinoco $(<0.2 \mu \mathrm{m})$ & 6.51 & 2500 & 124 & 452 & 2000 & - \\
& & & & & & \\
Congo & 6.19 & 3400 & - & - & 2465 & - \\
& & & & & & \\
Changjang & 7.8 & 555 & 18 & - & 485 & - \\
Fly & 7.8 & - & - & 267 & 180 & 87 \\
Sepik & 7.3 & 110 & - & 283 & 250 & 81 \\
Gironde & 7.3 & 140 & 60 & 258 & 263 & 68 \\
Luce & 4.5 & 140 & 43 & 749 & 367 & 73 \\
Tamar Springs & 7.25 & 35 & 17.3 & - & 257 & 65 \\
Tamar Neaps & 7.25 & 43 & 34 & - & 229 & 40 \\
\hline Dat & & & & & & \\
\hline
\end{tabular}

${ }^{\mathrm{a}}$ Data are compiled from a number of sources following the recent summary of Rousseau et al. (2015) that reported all the data published to date for Nd in surface water estuaries. Sources in addition to those cited by Rousseau et al. (2015) include: Sholkovitz and Copland (1981),

Goldstein and Jacobsen (1988a), Elderfield et al. (1990), Fox (1990), Sholkovitz (1992, 1993, 1995), Dupré et al. (1996), Kraepiel et al. (1997), Sholkovitz and Szymczak (2000), Gaillardet et al. (2005), and Milliman and Farnsworth (2011).

${ }^{\mathrm{b}}$ The percent of dissolved river-borne $\mathrm{Nd}$ removed in the estuary as computed by Rousseau et al. (2015).

${ }^{c}$ Filtrate passed through $0.2 \mu \mathrm{m}$ pore-size filters 
Table 4. Rare earth element concentrations and relative standard deviation (in pmol $\mathrm{kg}^{-1}$ ) for coastal groundwaters and seawater from the Kona Coast of Hawaii. The relative standard deviation is based on five replicate analyses of each sample. KAHO 1-D is a duplicate sample from the KAHO 1 well.

\begin{tabular}{|c|c|c|c|c|c|c|c|}
\hline & $\begin{array}{l}\text { Seawater } \\
(0.45 \mu \mathrm{m})\end{array}$ & $\begin{array}{l}\text { HH Well } \\
(0.45 \mu \mathrm{m})\end{array}$ & $\begin{array}{l}\text { KAHO } 1 \\
(0.45 \mu \mathrm{m})\end{array}$ & $\begin{array}{l}\text { KAHO 1-D } \\
(0.45 \mu \mathrm{m})\end{array}$ & $\begin{array}{l}\text { KAHO } 2 \\
(0.45 \mu \mathrm{m})\end{array}$ & $\begin{array}{l}\text { KAHO } 3 \\
(0.45 \mu \mathrm{m})\end{array}$ & $\begin{array}{l}\text { Hind Well } \\
(0.45 \mu \mathrm{m})\end{array}$ \\
\hline $\mathrm{La}$ & $127 \pm 0.58$ & $133 \pm 1.01$ & $161 \pm 1.18$ & $133 \pm 0.98$ & $137 \pm 1.29$ & $129 \pm 0.65$ & $140 \pm 0.74$ \\
\hline $\mathrm{Ce}$ & $329 \pm 2.25$ & $342 \pm 0.8$ & $359 \pm 1.72$ & $313 \pm 0.31$ & $352 \pm 1.79$ & $297 \pm 1.91$ & $371 \pm 3.93$ \\
\hline $\mathrm{Pr}$ & $35.1 \pm 0.24$ & $39.6 \pm 0.28$ & $44.1 \pm 0.8$ & $37.2 \pm 0.15$ & $39.9 \pm 0.07$ & $35.7 \pm 0.07$ & $42.7 \pm 1.02$ \\
\hline $\mathrm{Nd}$ & $169 \pm 4.1$ & $179 \pm 1.53$ & $191 \pm 2.4$ & $171 \pm 1.97$ & $174 \pm 1.57$ & $158 \pm 2.44$ & $192 \pm 2.6$ \\
\hline Sm & $32.1 \pm 1.15$ & $43.2 \pm 0.35$ & $42.7 \pm 1.8$ & $34.3 \pm 0.56$ & $46.1 \pm 1.91$ & $32.8 \pm 0.69$ & $40.3 \pm 1.35$ \\
\hline $\mathrm{Eu}$ & $7.02 \pm 0.42$ & $13 \pm 0.27$ & $13.1 \pm 0.16$ & $9.63 \pm 0.05$ & $12.4 \pm 0.17$ & $10.9 \pm 0.19$ & $12.2 \pm 0.29$ \\
\hline $\mathrm{Gd}$ & $43.2 \pm 0.58$ & $192 \pm 2.77$ & $41.5 \pm 1.26$ & $36.7 \pm 0.85$ & $39.4 \pm 1.3$ & $35.7 \pm 0.92$ & $41.2 \pm 1.09$ \\
\hline $\mathrm{Tb}$ & $4.47 \pm 0.06$ & $6.45 \pm 0.16$ & $6.57 \pm 0.11$ & $5.59 \pm 0.04$ & $5.76 \pm 0.12$ & $5.1 \pm 0.07$ & $6.62 \pm 0.1$ \\
\hline Dy & $26.1 \pm 0.5$ & $34.9 \pm 0.5$ & $35.9 \pm 0.53$ & $34 \pm 1.68$ & $32.6 \pm 0.64$ & $29.4 \pm 0.42$ & $36.5 \pm 0.63$ \\
\hline Ho & $5.94 \pm 0.47$ & $7.6 \pm 0.15$ & $8.19 \pm 0.18$ & $7.37 \pm 0.12$ & $10.4 \pm 0.06$ & $6.08 \pm 0.1$ & $7.95 \pm 0.06$ \\
\hline Er & $17.9 \pm 0.85$ & $23.4 \pm 0.28$ & $24.8 \pm 1.06$ & $23.6 \pm 0.59$ & $23.1 \pm 0.53$ & $20.4 \pm 0.61$ & $25.7 \pm 0.34$ \\
\hline $\mathrm{Tm}$ & $2.4 \pm 0.21$ & $3.37 \pm 0.11$ & $3.55 \pm 0.11$ & $3.56 \pm 0.12$ & $3.06 \pm 0.05$ & $2.62 \pm 0.03$ & $3.59 \pm 0.16$ \\
\hline $\mathrm{Yb}$ & $15.4 \pm 1.26$ & $22.7 \pm 0.76$ & $23 \pm 0.48$ & $21.2 \pm 0.59$ & $20.1 \pm 0.47$ & $16.7 \pm 0.6$ & $22.7 \pm 0.42$ \\
\hline $\mathrm{Lu}$ & $2.56 \pm 0.18$ & $3.94 \pm 0.08$ & $4.21 \pm 0.05$ & $4.05 \pm 0.03$ & $3.51 \pm 0.03$ & $2.92 \pm 0.05$ & $4.09 \pm 0.04$ \\
\hline $\mathrm{Ce} / \mathrm{Ce}^{*}$ & 1.13 & 1.01 & 0.98 & 1.02 & 1.09 & 1.0 & 1.09 \\
\hline $\mathrm{Eu} / \mathrm{Eu}^{*}$ & 1.1 & 1.47 & 1.48 & 1.33 & 1.4 & 1.2 & 1.44 \\
\hline $\mathrm{Gd} / \mathrm{Gd}^{*}$ & 1.6 & 5.05 & 1.08 & 1.14 & 1.09 & 1.02 & 1.08 \\
\hline \multirow[t]{2}{*}{$(\mathrm{Yb} / \mathrm{Nd})_{\mathrm{SN}}$} & 1.25 & 1.74 & 1.65 & 1.7 & 1.59 & 1.45 & 1.62 \\
\hline & $\begin{array}{l}\text { Seawater } \\
(0.02 \mu \mathrm{m})\end{array}$ & $\begin{array}{l}\text { HH Well } \\
(0.02 \mu \mathrm{m})\end{array}$ & $\begin{array}{l}\text { KAHO } 1 \\
(0.02 \mu \mathrm{m})\end{array}$ & $\begin{array}{l}\text { KAHO 1-D } \\
(0.02 \mu \mathrm{m})\end{array}$ & $\begin{array}{l}\text { KAHO } 2 \\
(0.02 \mu \mathrm{m})\end{array}$ & $\begin{array}{l}\text { KAHO } 3 \\
(0.02 \mu \mathrm{m})\end{array}$ & $\begin{array}{l}\text { Hind Well } \\
(0.02 \mu \mathrm{m})\end{array}$ \\
\hline $\mathrm{La}$ & $167 \pm 0.62$ & $146 \pm 0.43$ & & & $137 \pm 1.5$ & $159 \pm 5.35$ & $140 \pm 1.25$ \\
\hline $\mathrm{Ce}$ & $419 \pm 4.7$ & $388 \pm 1.28$ & & & $358 \pm 1.2$ & $398 \pm 4.06$ & $372 \pm 1.91$ \\
\hline $\operatorname{Pr}$ & $40.8 \pm 0.83$ & $41 \pm 1.43$ & & & $40.1 \pm 0.12$ & $42 \pm 0.93$ & $41.4 \pm 0.77$ \\
\hline $\mathrm{Nd}$ & $191 \pm 6.64$ & $192 \pm 4.04$ & & & $182 \pm 2.12$ & $194 \pm 6.7$ & $189 \pm 2.96$ \\
\hline Sm & $37 \pm 2.56$ & $38.4 \pm 1.85$ & & & $37.9 \pm 1.57$ & $39.6 \pm 2.26$ & $41.8 \pm 1.3$ \\
\hline $\mathrm{Eu}$ & $7.48 \pm 0.48$ & $8.75 \pm 0.21$ & & & $10.7 \pm 0.28$ & $9.77 \pm 1.03$ & $9.65 \pm 0.3$ \\
\hline $\mathrm{Gd}$ & $38.3 \pm 2.58$ & $216 \pm 4.14$ & & & $41.7 \pm 0.68$ & $42.2 \pm 2.05$ & $38.7 \pm 1.39$ \\
\hline $\mathrm{Tb}$ & $4.21 \pm 0.17$ & $5.16 \pm 0.12$ & & & $5.98 \pm 0.22$ & $6.52 \pm 1.24$ & $6.04 \pm 0.03$ \\
\hline Dy & $29.3 \pm 2.32$ & $35.4 \pm 2.36$ & & & $33.4 \pm 1.56$ & $35.5 \pm 2.19$ & $34.3 \pm 1.13$ \\
\hline Ho & $5.78 \pm 0.11$ & $7.61 \pm 0.11$ & & & $7.66 \pm 0.08$ & $7.63 \pm 0.08$ & $7.58 \pm 0.22$ \\
\hline Er & $16.8 \pm 0.5$ & $23 \pm 0.24$ & & & $24 \pm 0.3$ & $23 \pm 1.14$ & $23.8 \pm 0.73$ \\
\hline $\mathrm{Tm}$ & $2.3 \pm 0.28$ & $3.16 \pm 0.24$ & & & $3.24 \pm 0.22$ & $3.27 \pm 0.04$ & $3.32 \pm 0.08$ \\
\hline $\mathrm{Yb}$ & $14.2 \pm 1.07$ & $24.1 \pm 0.79$ & & & $21 \pm 0.59$ & $20.3 \pm 1.18$ & $21.5 \pm 0.87$ \\
\hline $\mathrm{Lu}$ & $2.4 \pm 0.27$ & $3.78 \pm 0.32$ & & & $3.79 \pm 0.21$ & $3.65 \pm 0.09$ & $3.93 \pm 0.11$ \\
\hline $\mathrm{Ce} / \mathrm{Ce}^{*}$ & 1.17 & 1.15 & & & 1.11 & 1.12 & 1.17 \\
\hline $\mathrm{Eu} / \mathrm{Eu} *$ & 1.09 & 1.16 & & & 1.36 & 1.17 & 1.15 \\
\hline $\mathrm{Gd} / \mathrm{Gd}^{*}$ & 1.4 & 6.84 & & & 1.2 & 1.13 & 1.1 \\
\hline$(\mathrm{Yb} / \mathrm{Nd})_{\mathrm{SN}}$ & 1.41 & 1.87 & & & 1.58 & 1.43 & 1.6 \\
\hline
\end{tabular}

$\mathrm{Ce} / \mathrm{Ce} *=[\mathrm{Ce} /(0.5 \mathrm{La}+0.5 \mathrm{Pr})]_{\mathrm{SN}}$.

$\mathrm{Eu} / \mathrm{Eu}^{*}=[\mathrm{Eu} /(0.67 \mathrm{Sm}+0.33 \mathrm{~Tb})]_{\mathrm{sN}}$.

$\mathrm{Gd} / \mathrm{Gd}^{*}=[\mathrm{Gd} /(0.33 \mathrm{Sm}+0.67 \mathrm{~Tb})]_{\mathrm{SN}}$.

SN = Post Archean Australian Shale (PAAS) normalized (Nance and Taylor, 1976; Taylor and McLennan, 1985). 
Table 5. Computed SGD fluxes of REEs using the results of the Honokohau Harbor mixing experiment and assuming that the terrestrial SGD at Honokohau Harbor is $8600 \mathrm{~m}^{3}$ day $^{-1}$ (Peterson et al., 2009).

\begin{tabular}{|c|c|c|c|c|c|c|}
\hline & $\begin{array}{c}\text { HH well } \\
\left(\mathrm{pmol} \mathrm{kg}^{-1}\right)\end{array}$ & $\begin{array}{c}\boldsymbol{J}_{\text {TSGD }}^{\mathrm{Ln}} \\
\left(\mu \mathrm{mol} \mathrm{day}^{-1}\right)^{\mathrm{a}}\end{array}$ & $\begin{array}{c}{[\mathrm{Ln}]_{\text {eff }}} \\
\left.(\mathrm{pmol} \mathrm{kg})^{-1}\right)^{\mathrm{b}, \mathrm{c}}\end{array}$ & $\begin{array}{c}\boldsymbol{J}_{\text {desorb }} \\
\left(\mu \text { ol day }^{-1}\right)^{\text {b,d }}\end{array}$ & $\begin{array}{c}\boldsymbol{J}^{\mathrm{Ln}} \operatorname{TotSGD}^{\mathrm{b}} \\
\left(\mu \mathrm{mol} \mathrm{day}^{-1}\right)^{\mathrm{b}, \mathrm{e}}\end{array}$ & $\begin{array}{c}\boldsymbol{J}_{\text {desorb }} \\
(\% \text { of TotSGD })^{\mathrm{b}}\end{array}$ \\
\hline $\mathrm{La}$ & 133 & 1144 & $201(170,239)$ & $585(318,912)$ & $1729(1462,2055)$ & $33.8(21.8,44.4)$ \\
\hline $\mathrm{Ce}$ & 342 & 2941 & $506(433,599)$ & $1410(783,2210)$ & $4352(3724,5151)$ & $32.4(21,42.9)$ \\
\hline $\operatorname{Pr}$ & 19.6 & 167 & $52.8(47.3,59.9)$ & $114(66.2,175)$ & $454(407,515)$ & $25(16.3,33.9)$ \\
\hline $\mathrm{Nd}$ & 179 & 1539 & $256(222,301)$ & $662(370,1049)$ & $2202(1909,2589)$ & $30.1(19.4,40.5)$ \\
\hline $\mathrm{Sm}$ & 43.2 & 372 & $56.3(45.1,76.9)$ & $113(17.2,290)$ & $484(389,661)$ & $23.3(4.42,43.8)$ \\
\hline $\mathrm{Eu}$ & 13 & 112 & $14.1(13.4,18.6)$ & $9.46(3.44,48.2)$ & $121(115$ & $7.8(2.99,30.1)$ \\
\hline $\mathrm{Gd}$ & 192 & 1651 & $236(226,256)$ & $378(292,550)$ & $2030(1944,2202)$ & $18.6(15,25)$ \\
\hline $\mathrm{Tb}$ & 6.45 & 55.5 & $9.65(7.47,15.6)$ & $27.5(8.77,78.7)$ & $83(64.2,134)$ & $33.2(13.7,58.7)$ \\
\hline Dy & 34.9 & 300 & $50.7(42.2,59.8)$ & $136(62.8,214)$ & $436(363,514)$ & $31.2(17.3,41.6)$ \\
\hline Ho & 7.6 & 65.4 & $10.3(8.7,12)$ & $23.2(9.46,37.8)$ & $88.6(74.8,103)$ & $26.2(12.6,36.7)$ \\
\hline $\mathrm{Er}$ & 23.4 & 201 & $30.8(26.5,36.5)$ & $63.3(26.7,113)$ & $265(228,314)$ & $24(11.7,35.9)$ \\
\hline $\mathrm{Tm}$ & 3.37 & 29 & $4.42(3.68,5.36)$ & $9.03(2.67,17.1)$ & $38(31.6,46.1)$ & $23.8(8.42,37.1)$ \\
\hline $\mathrm{Yb}$ & 22.7 & 195 & $32.5(27.3,38.6)$ & $84.3(39$ & $280(235,332)$ & $30.2(16.8,41.2)$ \\
\hline $\mathrm{Lu}$ & 3.94 & 33.9 & $5.07(4.28,6.04)$ & $9.72(2.92,7.94)$ & $43.6(36.8,51.9)$ & $22.3(7.94,34.8)$ \\
\hline
\end{tabular}

${ }^{\mathrm{a}}[\mathrm{Ln}]_{\mathrm{TSGD}} \times \mathrm{Q}_{\mathrm{TSGD}}$, where $[\mathrm{Ln}]_{\mathrm{TSGD}}$ is REE concentrations of Honokohau Harbor (i.e., HH) well $\left(\mathrm{pmol} \mathrm{kg}^{-1}\right)$ and $\mathrm{Q}_{\mathrm{TSGD}}$ $=8600 \mathrm{~m}^{3}$ day $^{-1}$, and TSGD indicates terrestrial submarine groundwater discharge (SGD).

${ }^{\mathrm{b}}$ Median value, with lower and upper bounds in parentheses.

${ }^{c}$ Left-hand side of equation 10. Represents the $y$-intercept at salinity zero on Figs. 12, EA4 - EA17.

${ }^{\mathrm{d}} \boldsymbol{J}_{\text {TotsGD }}-\boldsymbol{J}^{\mathrm{Ln}}{ }_{\text {TSGD }}^{\mathrm{L}}$, where TotSGD is the total SGD.

${ }^{\mathrm{e}}[\mathrm{Ln}]_{\mathrm{eff}} \times \mathrm{Q}_{\mathrm{TSGD}}$, where $\mathrm{Q}_{\mathrm{TSGD}}=8600 \mathrm{~m}^{3}$ day $^{-1}$.

Table 6. Computed SGD fluxes of REEs using the results of the Lava Tube mixing experiment and assuming that the terrestrial SGD at Kiholo Bay is $6300 \mathrm{~m}^{3}$ day $^{-1}$ (Peterson et al., 2009).

\begin{tabular}{lcccccc}
\hline & $\begin{array}{c}\text { Hind well } \\
\left(\mathrm{pmol} \mathrm{kg}^{-1}\right)\end{array}$ & $\begin{array}{c}\left.\boldsymbol{J}^{\mathrm{Ln}} \text { TSGD }^{-1} \mathrm{~mol} \mathrm{day}^{-1}\right)^{\mathrm{a}} \\
\left(\mathrm{pmol} \mathrm{kg}^{-1}\right)^{\mathrm{b}, \mathrm{c}}\end{array}$ & $\begin{array}{c}\mathrm{J}_{\text {desorb }} \\
\left(\mu \mathrm{mol} \mathrm{day}^{-1}\right)^{\mathrm{b}, \mathrm{d}}\end{array}$ & $\begin{array}{c}\boldsymbol{J}_{\text {TotsGD }}^{\mathrm{Ln}} \\
\left(\mu \mathrm{mol} \mathrm{day}^{-1}\right)^{\mathrm{b}, \mathrm{e}}\end{array}$ & $\begin{array}{c}\boldsymbol{J}_{\text {desorb }} \\
(\% \text { of TotSGD })^{\mathrm{b}}\end{array}$ \\
\hline $\mathrm{La}$ & 140 & 882 & $179(161,221)$ & $246(132,510)$ & $1128(1014,1392)$ & $21.8(13,36.7)$ \\
$\mathrm{Ce}$ & 371 & 2337 & $467(418,565)$ & $605(296,1222)$ & $2942(2633,3560)$ & $20.6(11.2,34.3)$ \\
$\mathrm{Pr}$ & 42.7 & 269 & $49.9(45.2,59)$ & $45.4(15.8,103)$ & $314(285,372)$ & $14.4(5.53,27.6)$ \\
$\mathrm{Nd}$ & 192 & 1210 & $230(205,270)$ & $239(81.9,491)$ & $1449(1292,1701)$ & $16.5(6.34,28.9)$ \\
$\mathrm{Sm}$ & 40.3 & 254 & $46(41.2,54.4)$ & $35.9(5.67,88.8)$ & $290(260,343)$ & $12.4(2.18,25.9)$ \\
$\mathrm{Eu}$ & 12.2 & 76.9 & $12.7(12,17)$ & $3.15(-1.3,30.2)^{\mathrm{f}}$ & $80(75.6,107)$ & $3.94(-1.7,28.2)^{\mathrm{f}}$ \\
$\mathrm{Gd}$ & 41.2 & 260 & $48.8(42.4,56.6)$ & $47.9(7.56,96.4)$ & $307(267,356)$ & $15.6(2.82,27.1)$ \\
$\mathrm{Tb}$ & 6.62 & 41.7 & $7.16(6.76,8.39)$ & $3.4(0.88,11.2)$ & $45.1(42.6,52.9)$ & $7.54(2.07,21.1)$ \\
$\mathrm{Dy}$ & 36.5 & 230 & $43.2(39.2,51.3)$ & $42.2(17,93.2)$ & $272(247,323)$ & $15.5(6.89,28.8)$ \\
$\mathrm{Ho}$ & 7.95 & 50.1 & $9.67(8.63,12.3)$ & $10.8(4.28,27.4)$ & $60.9(54.4,77.5)$ & $17.8(7.88,35.5)$ \\
$\mathrm{Er}$ & 25.7 & 162 & $29.3(26.8,35.2)$ & $22.7(6.93,59.9)$ & $185(169,222)$ & $12.3(4.1,27)$ \\
$\mathrm{Tm}$ & 3.59 & 22.6 & $4.53(4,5.71)$ & $5.92(2.58,13.4)$ & $28.5(25.2,36)$ & $20.8(10.3,37.1)$ \\
$\mathrm{Yb}$ & 22.7 & 143 & $28.5(25.5,36.3)$ & $36.5(17.6,85.7)$ & $180(161,229)$ & $20.4(11,37.5)$ \\
$\mathrm{Lu}$ & 4.09 & 25.8 & $4.74(4.28,5.75)$ & $4.1(1.2,10.5)$ & $29.9(27,36.2)$ & $13.7(4.22,28.9)$ \\
\hline
\end{tabular}

${ }^{a}[\mathrm{Ln}]_{\mathrm{TSGD}} \times \mathrm{Q}_{\mathrm{TSGD}}$, where $[\mathrm{Ln}]_{\mathrm{TSGD}}$ is REE concentrations of Hind well $\left(\mathrm{pmol} \mathrm{kg}^{-1}\right)$ and $\mathrm{Q}_{\mathrm{TSGD}}=6300 \mathrm{~m}^{3} \mathrm{day}^{-1}$, and TSGD indicates terrestrial submarine groundwater discharge (SGD).

${ }^{\mathrm{b}}$ Median value, with lower and upper bounds in parentheses.

${ }^{c}$ Left-hand side of equation 10. Represents the $y$-intercept at salinity zero on Figs. 12, EA4 - EA17.

${ }^{\mathrm{d}} \boldsymbol{J}^{\mathrm{Ln}}{ }_{\text {TotSGD }}-\boldsymbol{J}^{\mathrm{Ln}}{ }_{\text {TSGD }}$, where TotSGD is the total SGD.

${ }^{\mathrm{e}}[\mathrm{Ln}]_{\mathrm{eff}} \times \mathrm{Q}_{\mathrm{TSGD}}$, where $\mathrm{Q}_{\mathrm{TSGD}}=6300 \mathrm{~m}^{3}$ day $^{-1}$.

${ }^{\mathrm{f}}$ Negative sign indicates uptake from solution. 


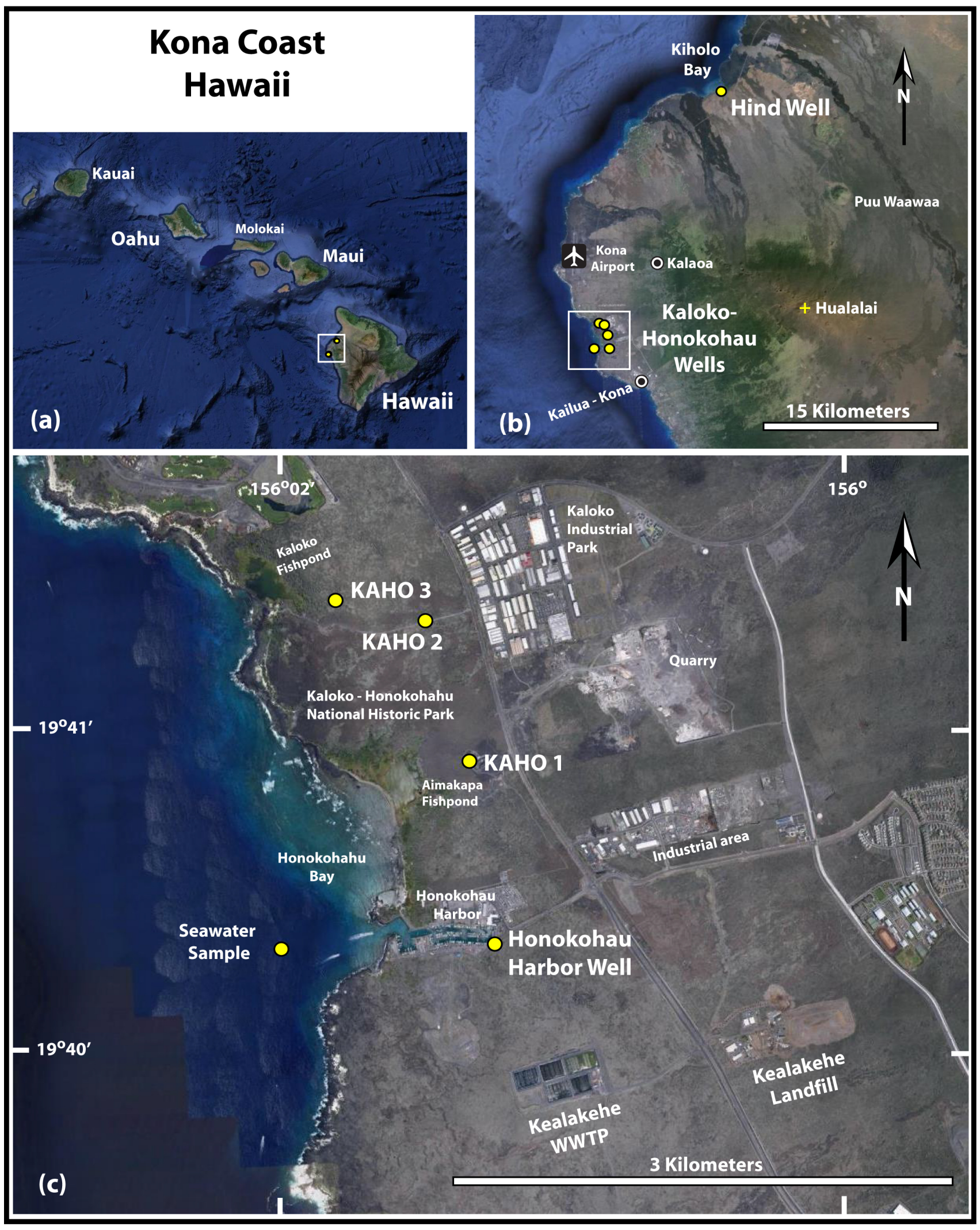

Figure 1 


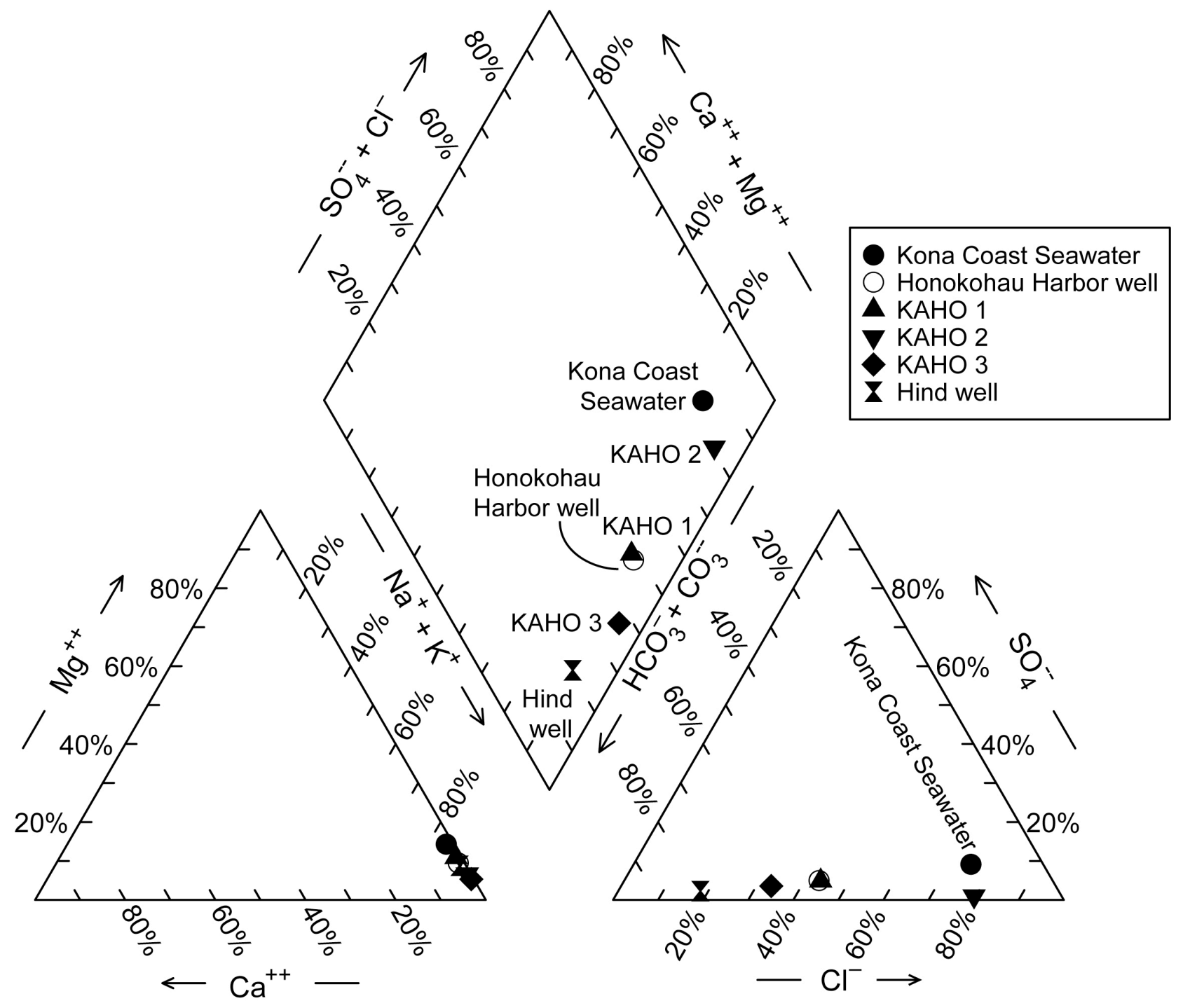

Figure 2 


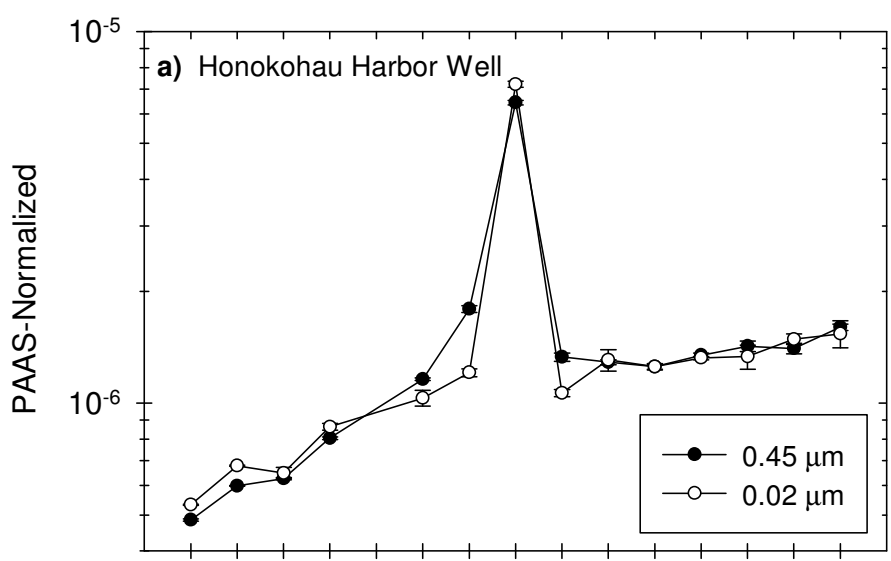

La Ce Pr Nd Pm Sm Eu Gd Tb Dy Ho Er Tm Yb Lu

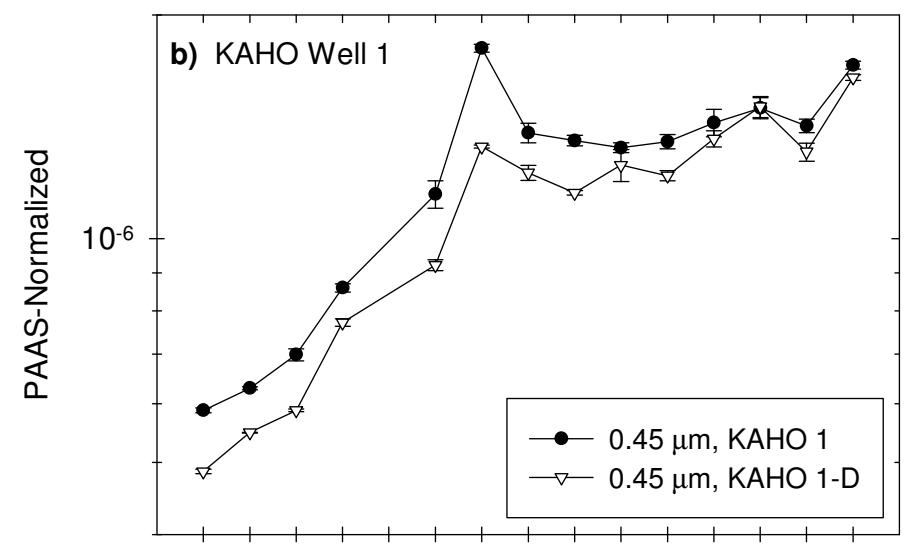

La Ce Pr Nd Pm Sm Eu Gd Tb Dy Ho Er Tm Yb Lu

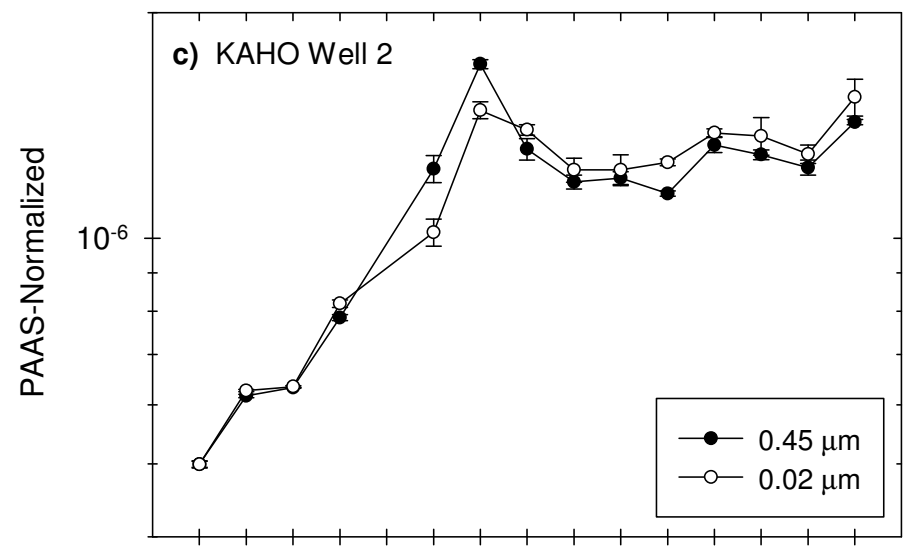

La Ce Pr Nd Pm Sm Eu Gd Tb Dy Ho Er Tm Yb Lu

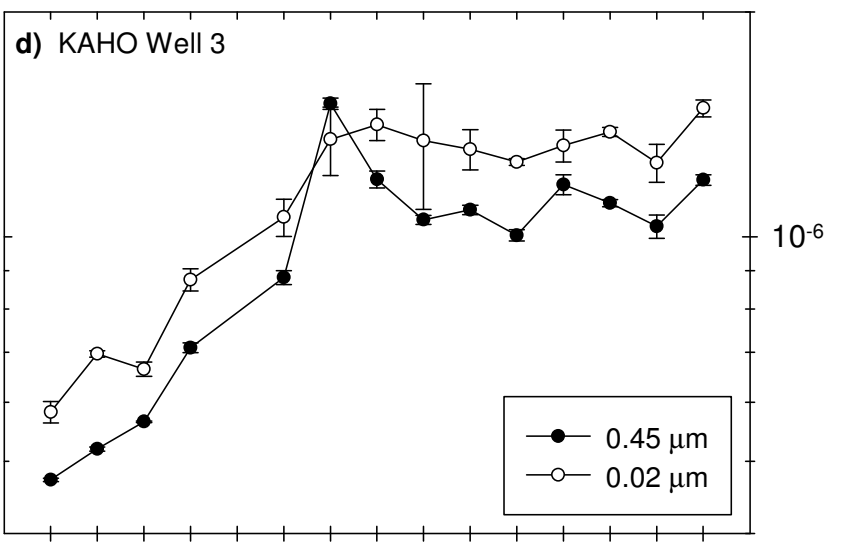

La Ce Pr Nd Pm Sm Eu Gd Tb Dy Ho Er Tm Yb Lu

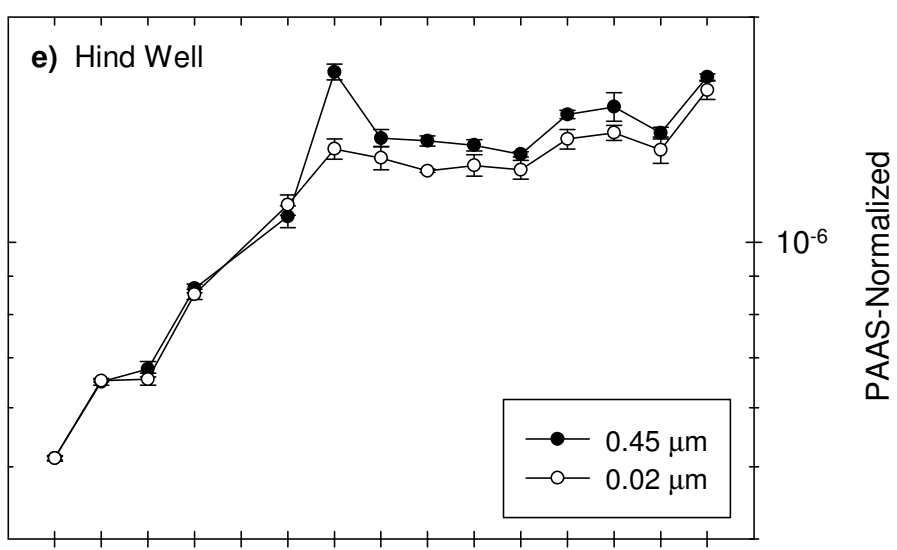

La Ce Pr Nd Pm Sm Eu Gd Tb Dy Ho Er Tm Yb Lu

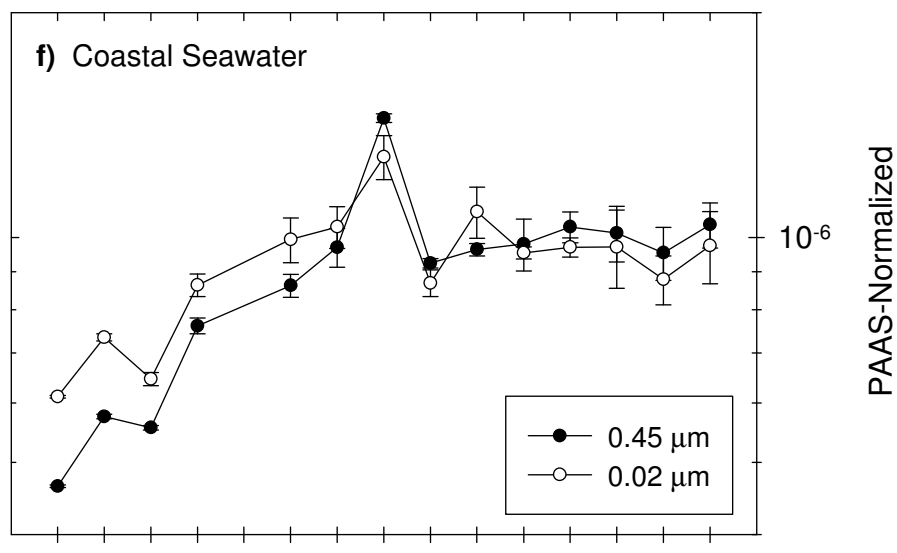

La Ce Pr Nd Pm Sm Eu Gd Tb Dy Ho Er Tm Yb Lu

Figure 3 

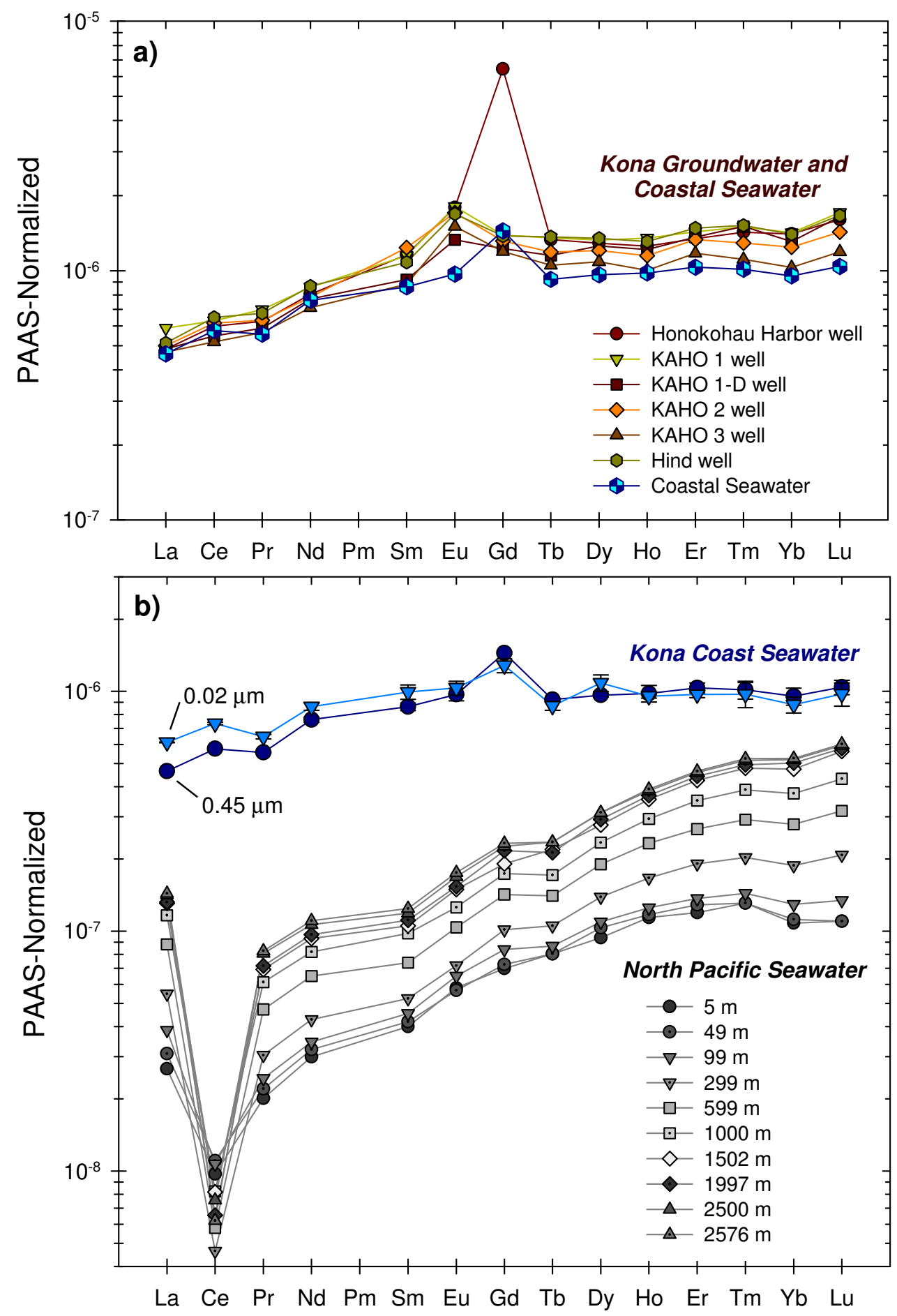

Figure 4 

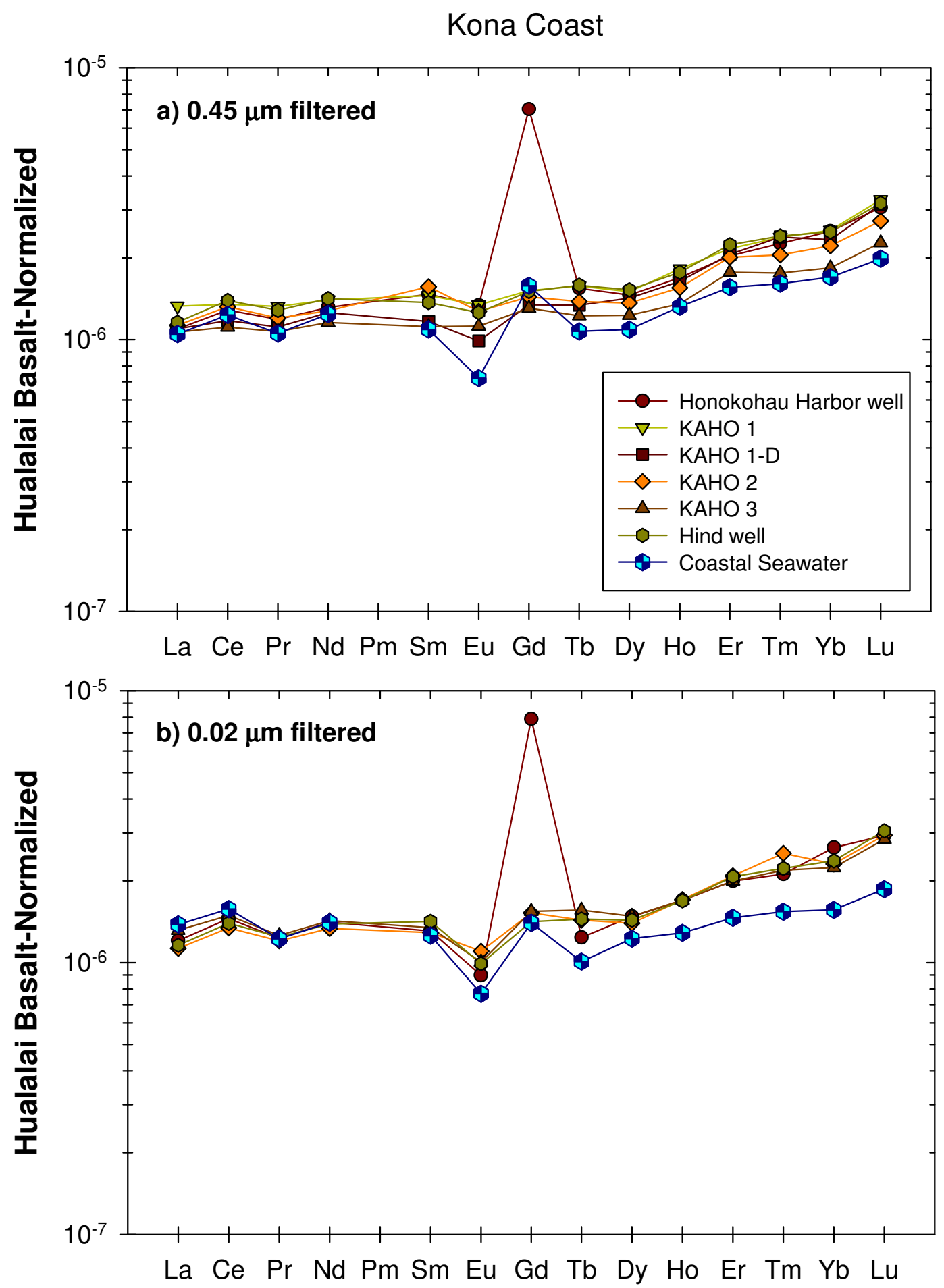

Figure 5 

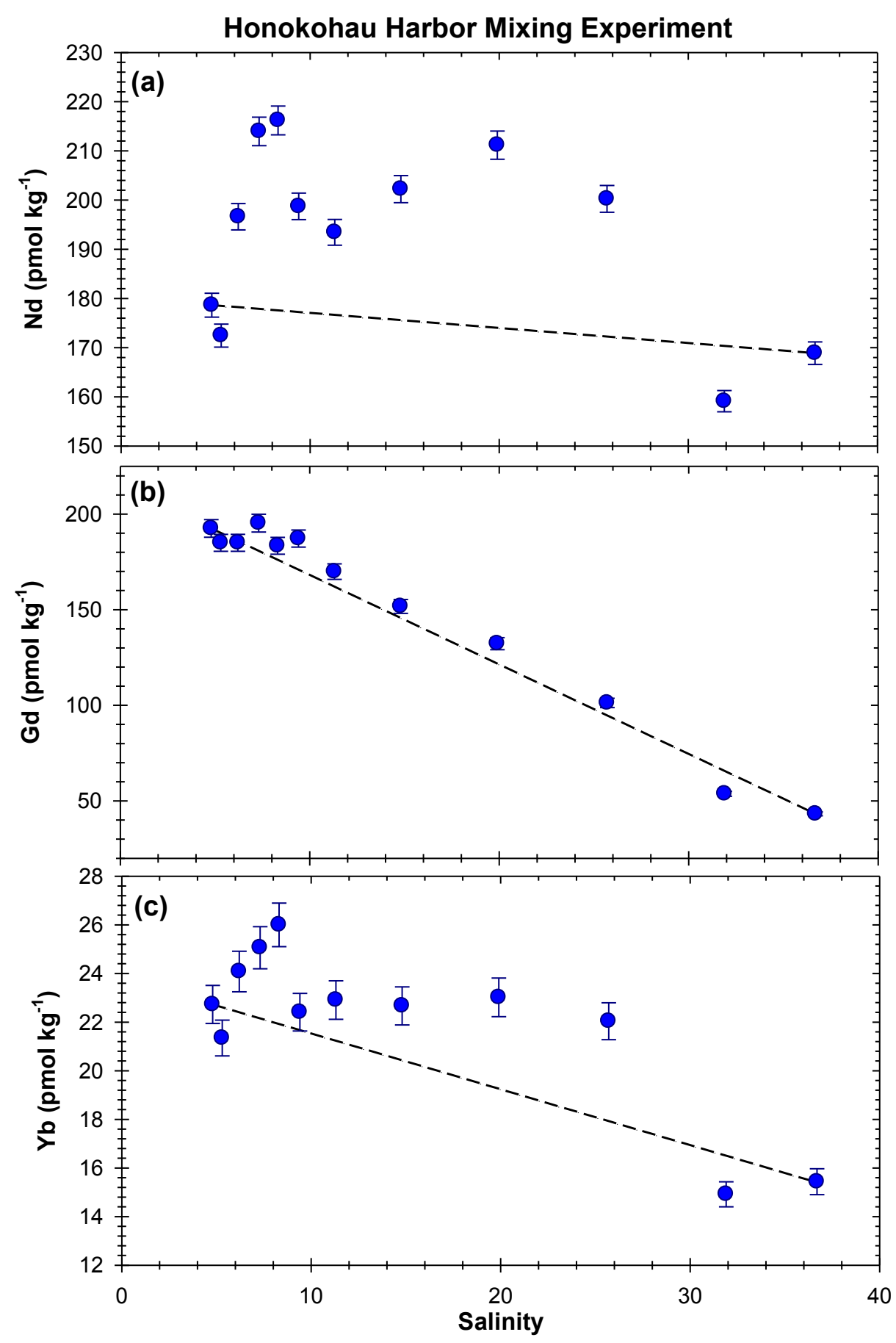

Figure 6 


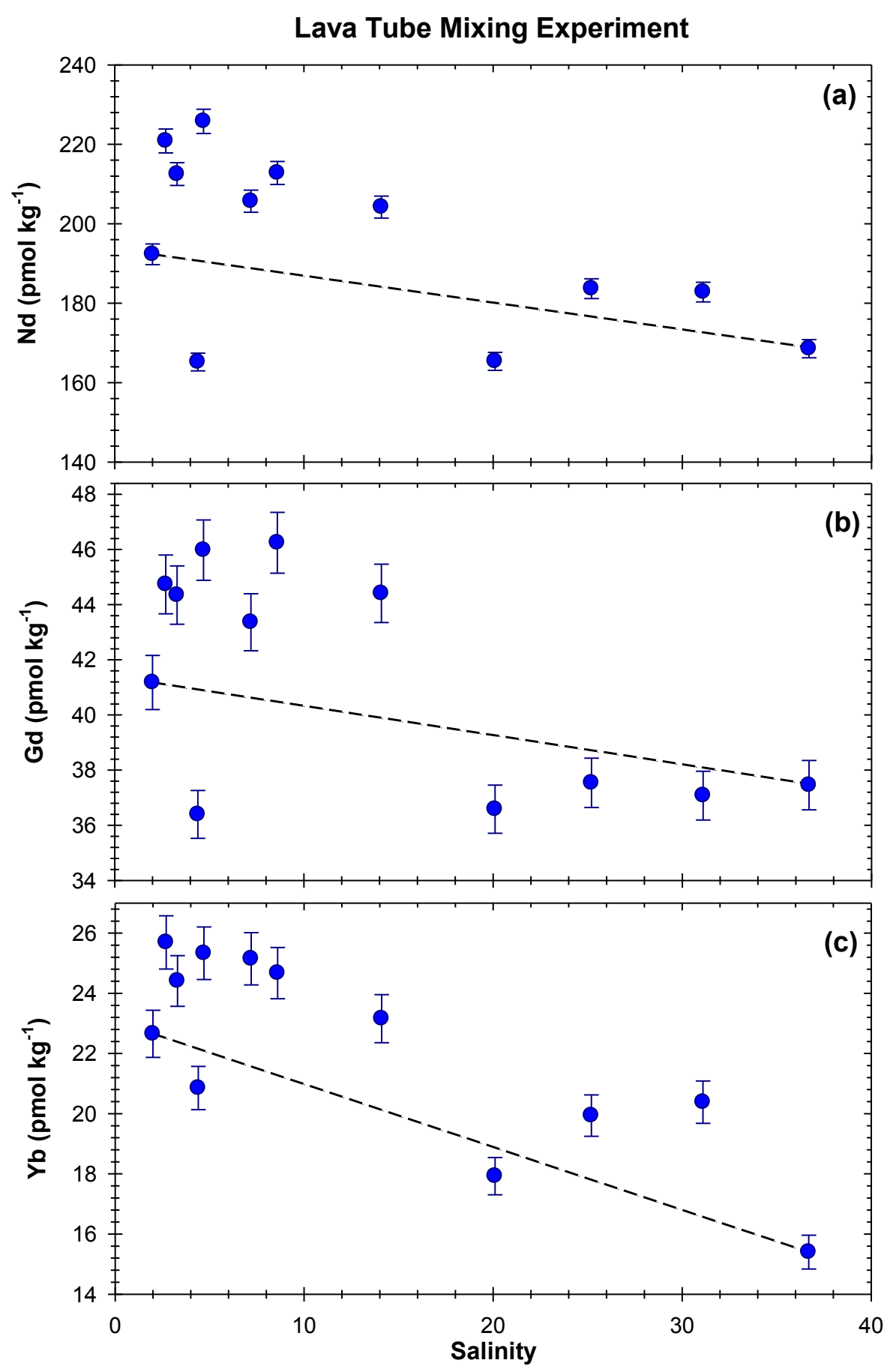

Figure 7 

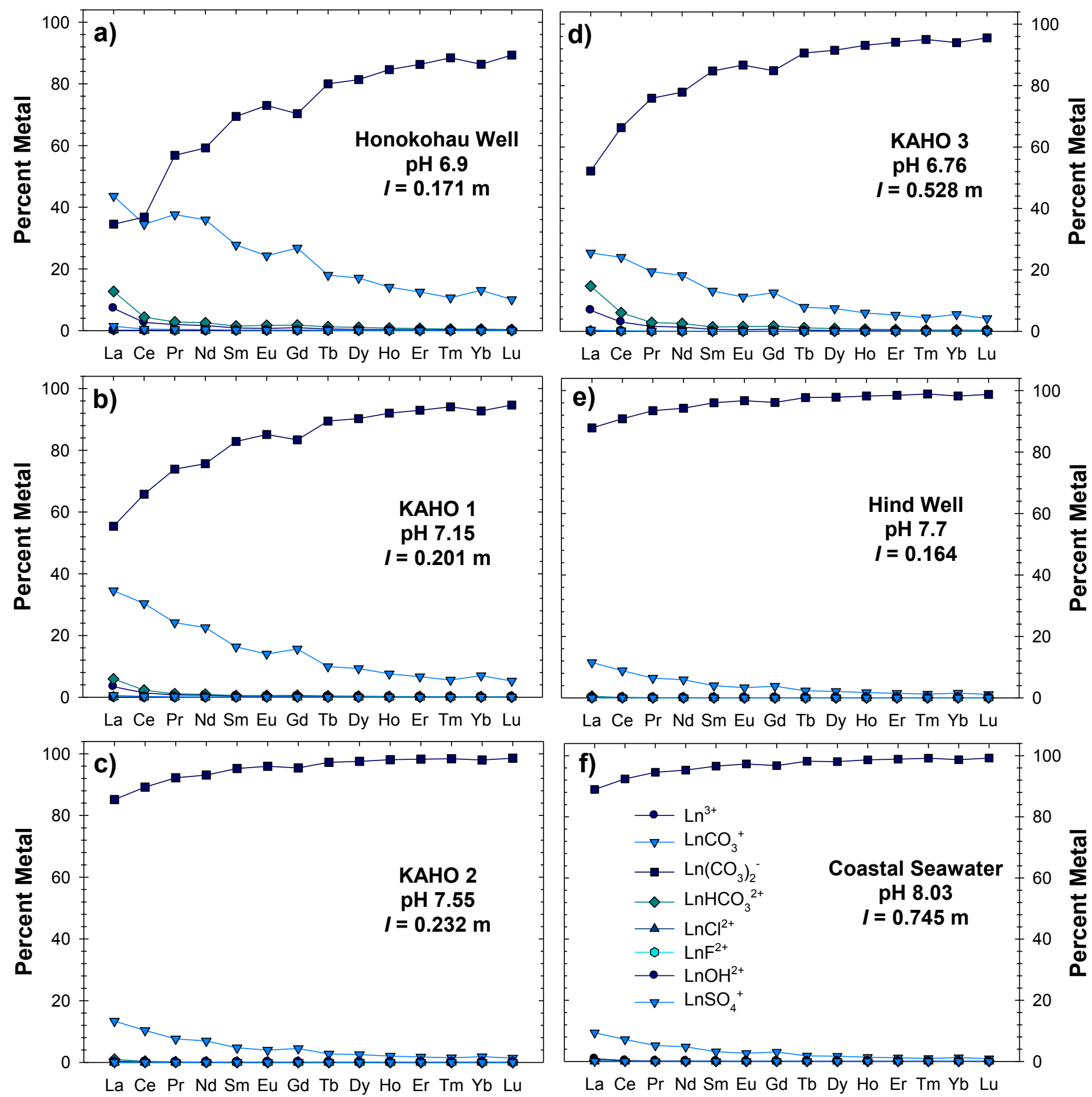

La Ce Pr Nd Sm Eu Gd Tb Dy Ho Er Tm Yb Lu

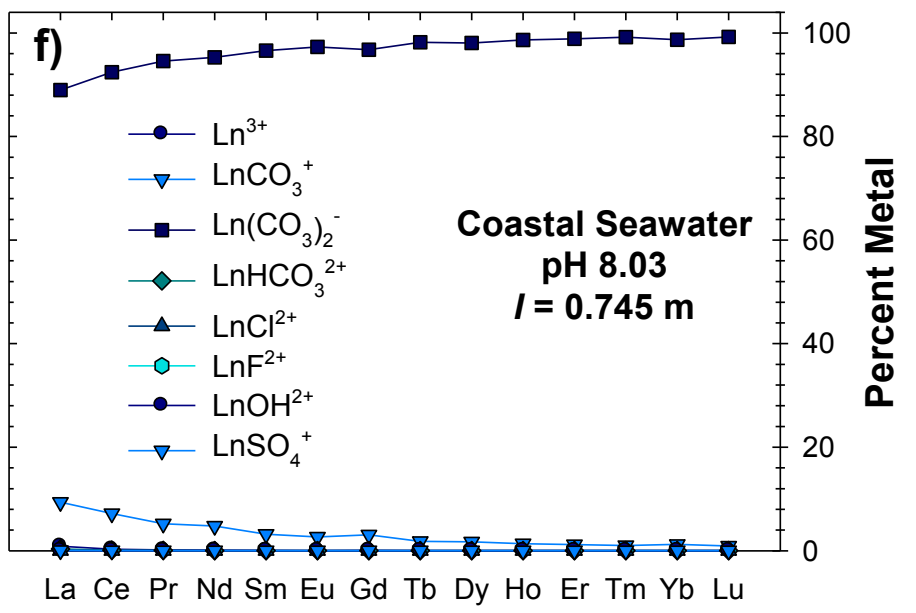

Figure 8 
Honokohau Harbor Mixing Experiment
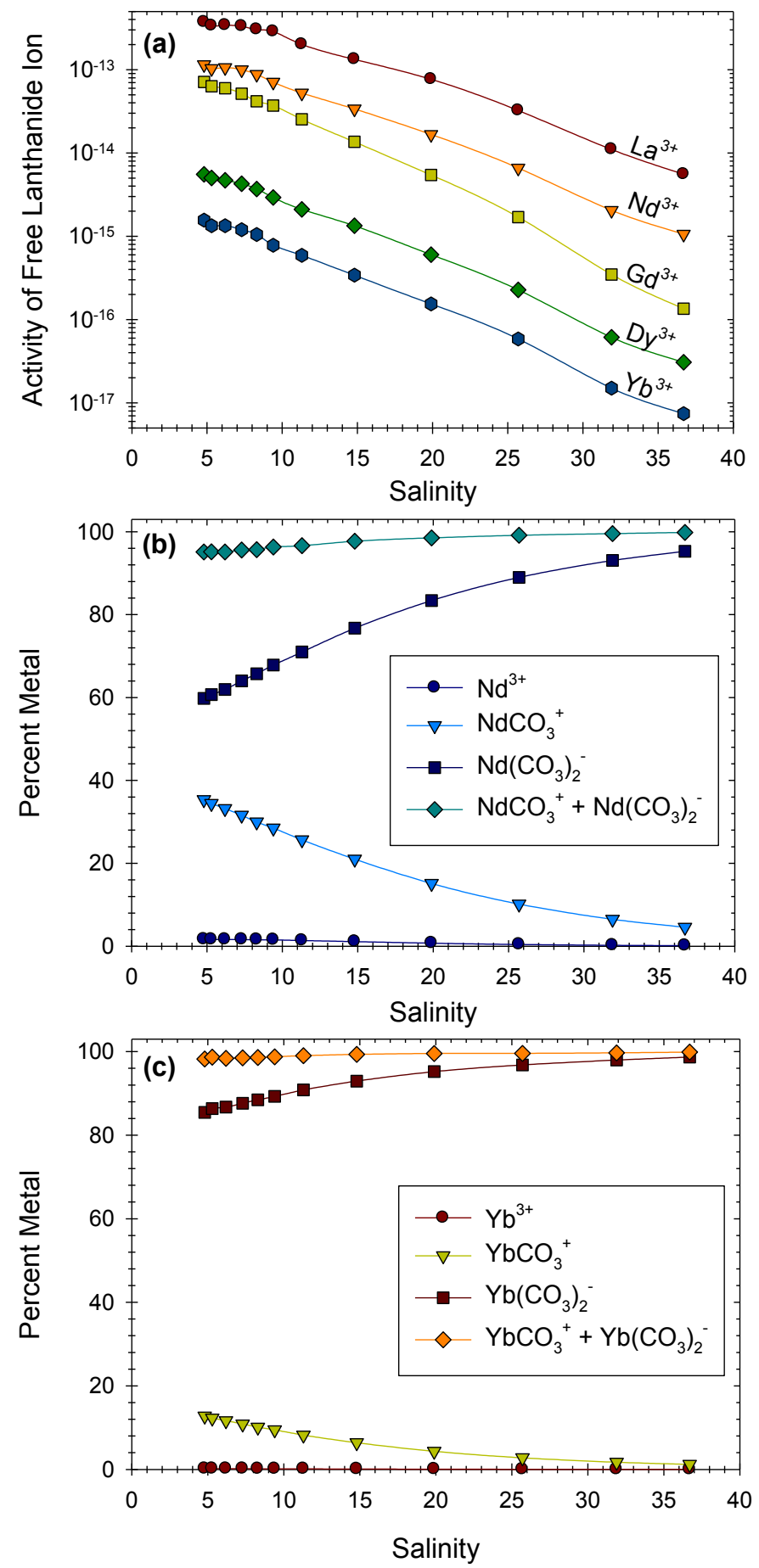

Figure 9 

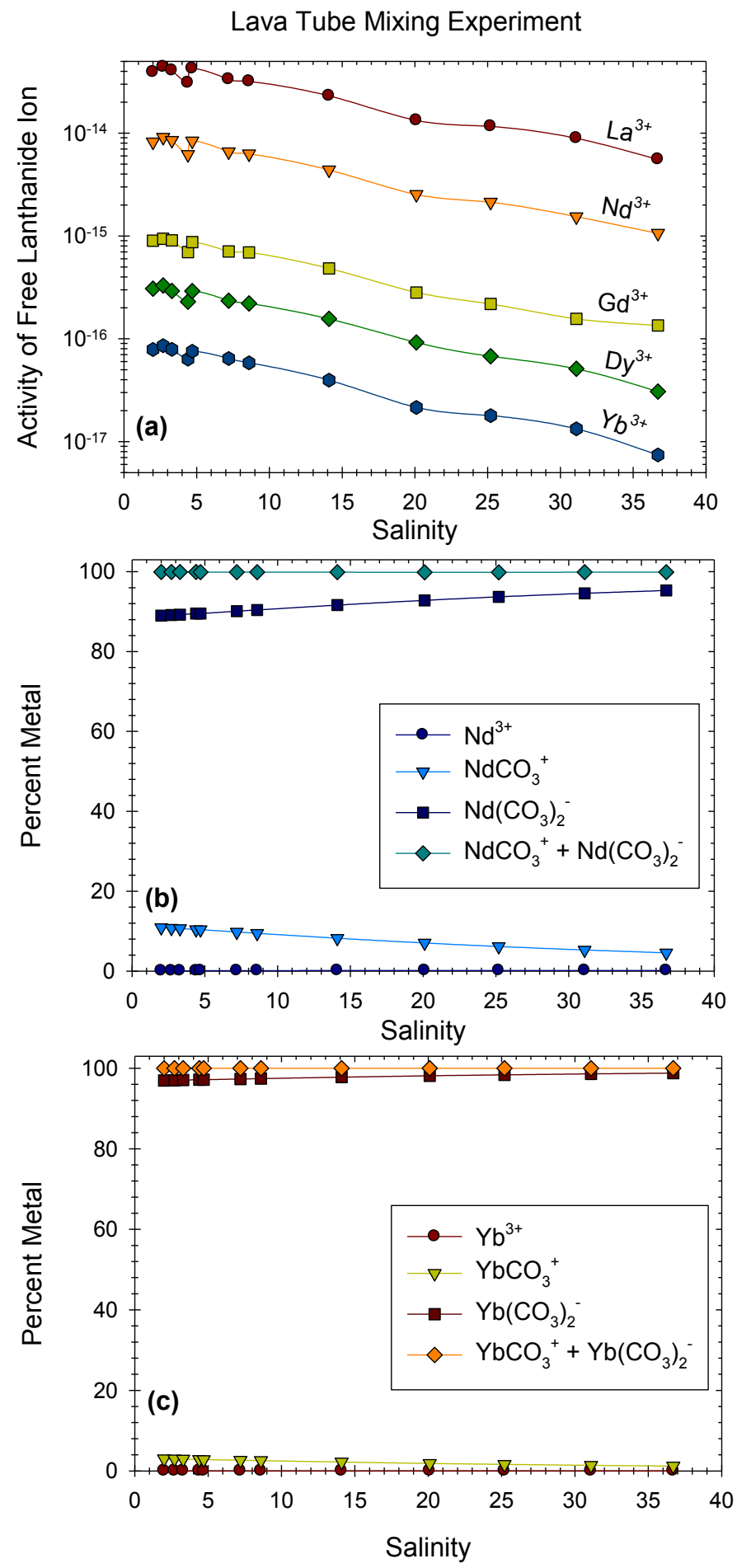

Figure 10 


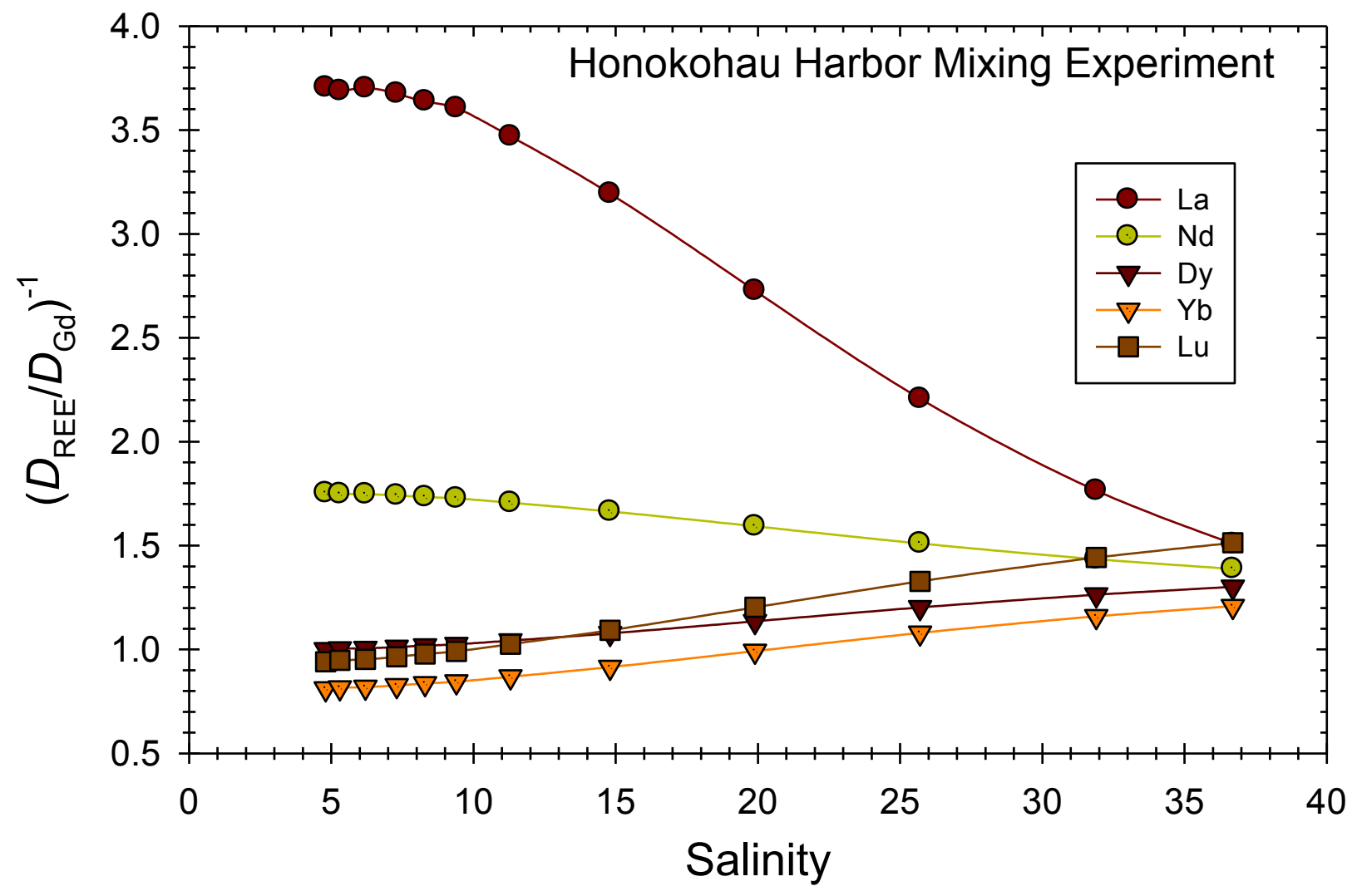

Figure 11 


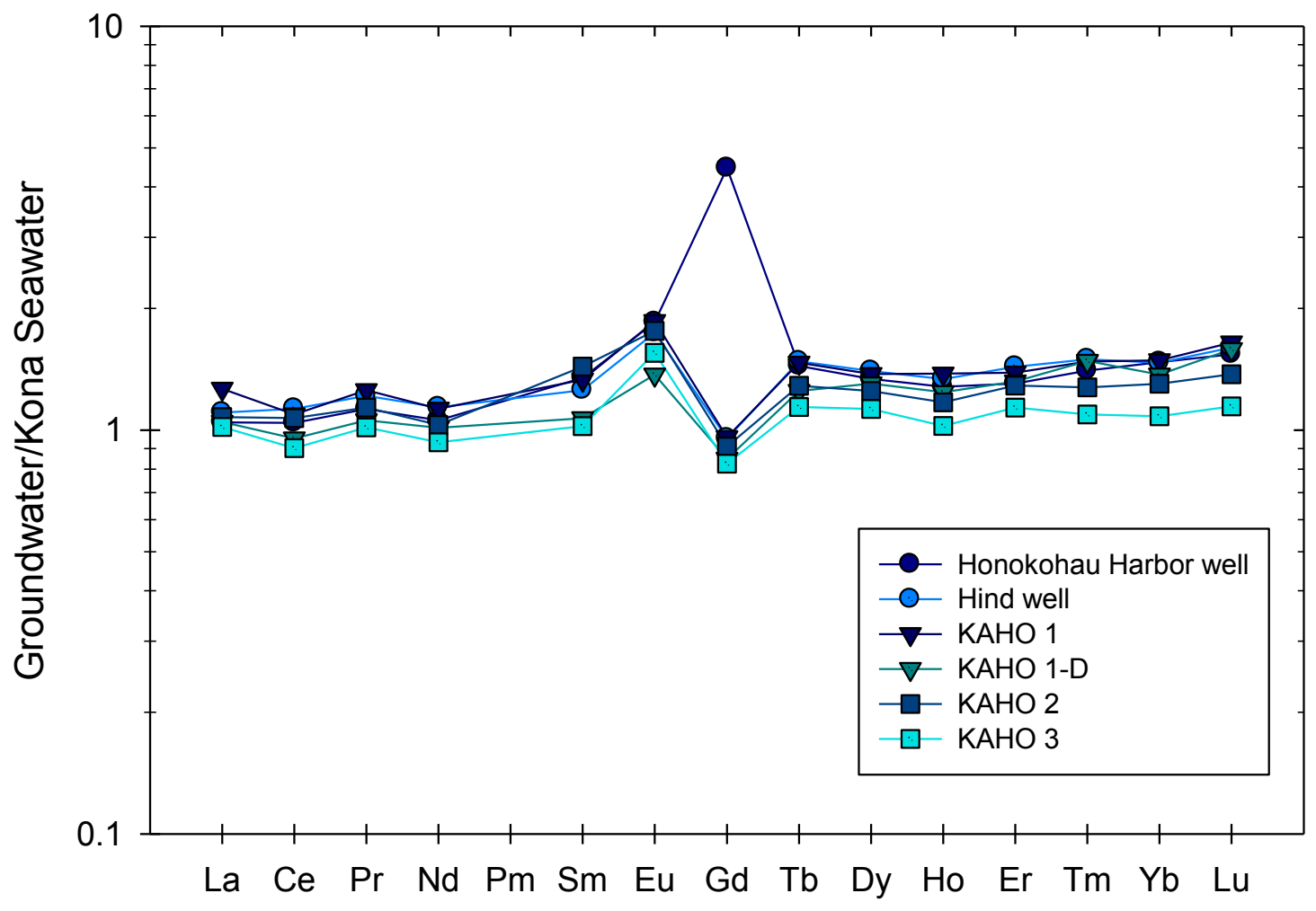

Figure 12 

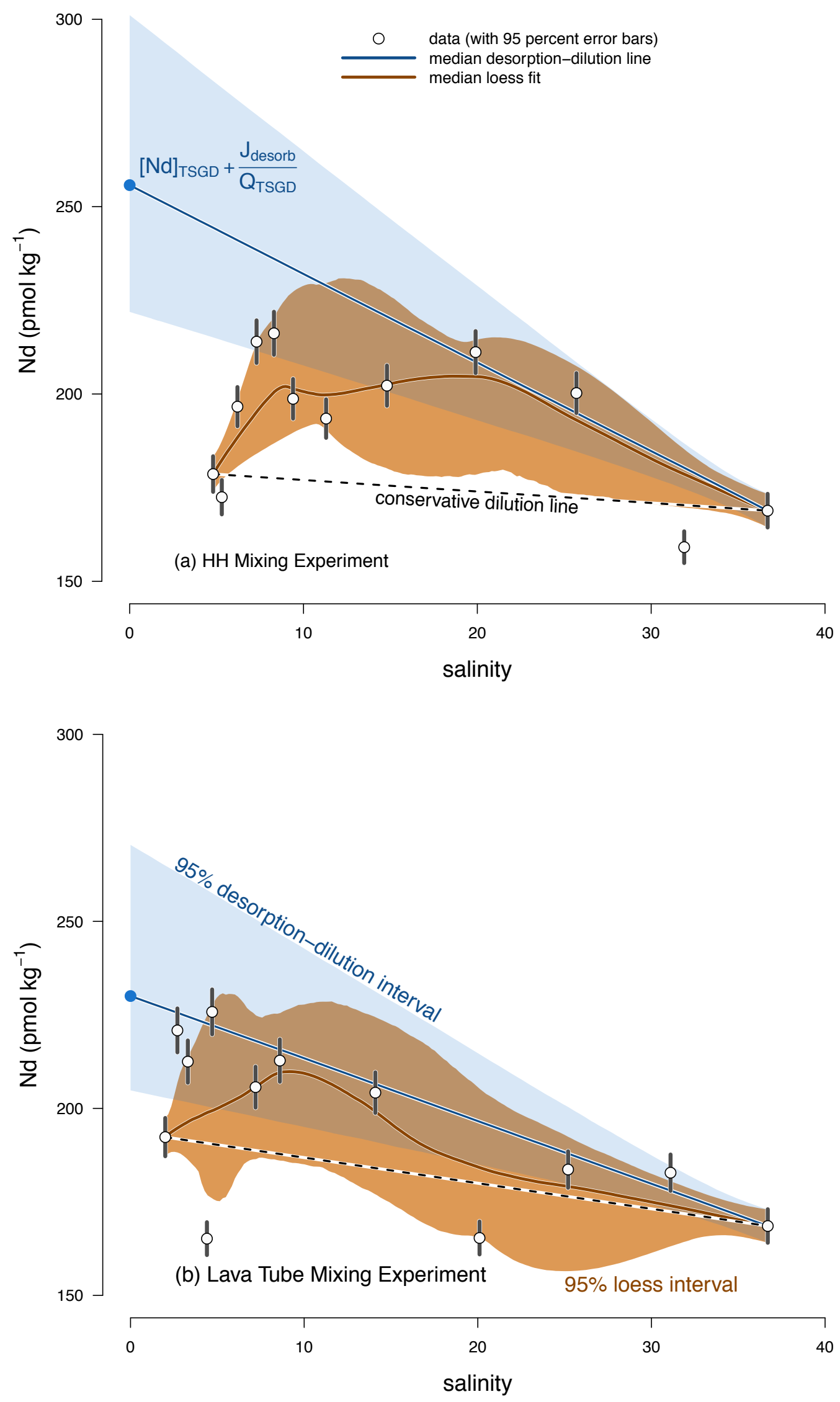

Figure 13 